\title{
The Court as a Meeting Point: Cohesion, Competition, Control
}

\author{
Jeroen Duindam \\ Introduction: Emerging Bureaucratic States versus Stagnant Palace \\ Polities?
}

In the grand narrative of European modernization the court was seen as a relic of the past. Late nineteenth- and early twentieth-century historians gave pride of place to specialized institutions of government and to representative bodies limiting the powers of the ruler, appreciated as the heralds of modernity. The rise of powerful 'absolutist' kings figured in traditional historiography as a necessary but transient phase that reduced restive nobilities to obedience, providing the foundation for a rational state apparatus that would soon get rid of its monarchical topping. ${ }^{1}$

Norbert Elias's The Court Society, largely written in the early 193os but first published in 1969, inserted the court into this classic view of state-formation. ${ }^{2}$ Elias's powerful interpretation of the French court under Louis XIV soon became the standard for scholarship on the court in many periods and regions, yet at the same time, its empirical basis and main conclusions were questioned by specialists of the French court. ${ }^{3}$ A comparative digression on the court, therefore, needs to start with this influential work. Elias outlined how a variety of mechanisms in French court life helped the ruler to gradually humble the great nobles, making them dependent on royal largesse and isolating them

1 See a recent statement of this view in Martin Van Creveld, The Rise and Decline of the State (Cambridge, 1999) many passages, but a particularly relevant statement on 130 (cited later in this chapter on 118 ).

2 Norbert Elias, The Court Society (Oxford, 1983 [1969]).

3 See discussion and bibliography in Jeroen Duindam, Myths of Power. Norbert Elias and the Early Modern European Court (Amsterdam, 1995); studies of the court taking Elias as point of orientation: A.J.S. Spawforth, The Court and Court Society in Ancient Monarchies (Cambridge, 2007); David Potter and Richard Talbert, eds., American Journal of Philology 132, no. 1 (2011) Special Issue Classical Courts and Courtiers; Lloyd Llewellyn, King and Court in Ancient Persia 559-331 вСE (Edinburgh, 2013).

(C) JEROEN DUINDAM, 2018 | DOI: 10.1163/9789004315716_003

This is an open access article distributed under the terms of the CC-BY-NC-ND License, 
from positions of power. This view of the court as a gilded cage for nobles was the key example of a mechanism postulated by Elias in his Civilizing Process. ${ }^{4}$ The expanding powers of state and king 'domesticated' nobles at court (Fremdzwang, external pressures), where they gradually embraced the norms of behaviour imposed on them (Selbstzwang, internalised pressure). Court nobles lost political power but became champions of social mores soon to be emulated by other groups.

The assumption that court office was largely apolitical would quickly be exposed as an anachronism. ${ }^{5}$ Most nobles serving their prince as privileged domestics combined high rank with political office. Access to the figure at the heart of the dynastic edifice was a prime opportunity: even lower-ranking domestics could use their intimacy with the prince to recommend their friends for benefits. The inner sphere of the court was a political domain because it entailed proximity to the redistribution of the wealth and perks accumulated at the centre. ${ }^{6}$ Scholarship on the early modern European court in the last two decades has made abundantly clear that political history needs to reintegrate the domestic setting of monarchy, adding relatives, spouses, and servants to its analytical palette.

This critical response to Elias's position immediately clarifies the relevance of wider comparison. Classic orientalist views inflated powers of Asian princes and pointed to the pervasive influence of their inner court favourites. Conversely, classic views of the European state disregarded the domestic setting of rulership and concentrated their attention on clerks, councils, and assemblies. Surely, however, in all realms, the inner component played a role, whereas 'outer court' bodies of advisors were present in Asia as well as in Europe. ${ }^{7}$ In his wide-ranging and erudite History of Government, Samuel Finer classifies Asian dynastic courts under the rubric of 'palace polities', where 'decision-making

4 Norbert Elias, The Civilizing Process (Oxford, 1994 [1939]).

5 This point was made by David Starkey in several influential contributions challenging Geoffrey Elton's view of the 'Tudor Revolution in Government', see Starkey, 'Representation Through Intimacy. A Study in the Symbolism of Monarchy and Court Office in Early-Modern England', in: Ioan Lewis, ed., Symbols and Sentiments. Cross-Cultural Studies in Symbolism (London, 1977) 187-224; Starkey, The English Court from the Wars of the Roses tot the Civil War (London and New York, 1987).

6 See the powerful and provocative analysis by Wolfgang Reinhard, 'Die Nase der Kleopatra. Geschichte im Lichte mikropolitischer Forschung. Ein Versuch', Historische Zeitschrift 293, no. 3 (2011) 633-666 and recently the synthesis by Jens Ivo Engels, Die Geschichte der Korruption (Frankfurt, 2014).

7 See, in this volume: Maaike van Berkel, 'The People of the Pen: Self-Perceptions of Status and Role in the Administration of Empires and Polities'. 
rests with one individual', influenced by domestics and consorts. Finer subsumes European absolute monarchies under the same heading, yet points to the rule of law and the presence of intermediate bodies as setting these courts apart from the Asian examples. ${ }^{8}$ It remains to be seen whether government institutions around the prince were invariably less independent in Asian polities. Chinese administrators were highly deferential in their dealings with the Son of Heaven and always remained subject to severe punishments, yet as a group they dominated government and held a much-respected place in society. Elsewhere in this volume, Maaike van Berkel shows that all other major Asian polities included differentiated government services outside of the domestic sphere, most of them with a longer historical pedigree than their European counterparts.

Another aspect of Elias's model needs to be mentioned. Founding emperors in the style of Zhu Yuanzhang or Napoleon Bonaparte inevitably were strong figures: they fought and manipulated to reach and secure their leading positions. Once dynasties were established and accepted, however, they could never count on the strength and wisdom of individual scions. By fixing rules of succession, they prevented bloody interregna, but risked putting weaklings on the throne. ${ }^{9}$ Elias raised a fundamental question: how can mediocre characters ascending to power through hereditary succession rule effectively? His examination of the French court can be read as an elaboration of Max Weber's concept of Veralltäglichung: a study of power in routine settings, the reverse image of charismatic personal rule in phases of turbulent change. ${ }^{10}$ Elias pointed to a number of subtle mechanisms related to the competition among elites at court, and to the potential of princes to rule by manipulating rivalries and balances of power and prestige. Paradoxically, however, these

8 Samuel E. Finer, The History of Government from the Earliest Times (Oxford and New York, 1997) vol. I, quote on 38 , typology developed $34-58$ with palace, forum, nobility, and church polities and their hybrid forms. A more marked contrast is developed in vol. II and III between European modernizing states and Asian palace polities, see e.g. III, 14551460, where the rule of law and the presence of intermediate bodies are defined as main differences between Asian and European forms of absolutism, and III, 1567 on the reduced variants after the French Revolution.

9 See the mirror image of this argument in Munis D. Faruqui, The Princes of the Mughal Empire, 1504-1719 (Cambridge, 2012) who suggests that the fierce succession struggles in the Mughal empire, if not repeated too frequently, reinvigorated imperial power; see below on Ottoman and Safavid practices.

10 Weber, 'Die Veralltäglichung des Charisma und ihre Wirkung', Wirtschaft und Gesellschaft, 144-148. 
mechanisms work only with mastermind-kings, versatile and perspicacious princes who manipulated friend and foe in a continuous, polite battle of gestures and phrases. By definition, rulers were the lynchpins of their courts, yet many among them proved unwilling or unable to exert the authority attributed to them. Fixed succession could never consistently produce conquering heroes or mastermind-kings: in fact many reigning kings left the business of ruling to their advisors and domestics. Even formidable characters were vulnerable in youth and old age.

The heavy and contradictory demands placed on the shoulders of kings, inculcated by their tutors with the expectations of tradition, were enough to intimidate talented youngsters into frightened passivity, or, conversely, to stir others to rebel violently against the constraints inherent in kingship. In his depiction of the Balinese 'icon king' Clifford Geertz may have exaggerated the passivity of the ritual king at the silent core of a whirlwind of power and competition. ${ }^{11}$ His view, however, helps us to take distance from the common overstatement of royal power, in its classic 'absolutist' form or in Elias's more nuanced variant of divide-and-rule. While the position of the king, sultan, or emperor could be unassailable at least in theory, the person on the throne was never necessarily the mover and shaker of his realm. The power of kings, therefore, should never be taken for granted. Neither can it be inferred from official sources generated by the court, presenting ideals rather than practices. The task of finding out who, in practice, wielded power behind the smoke screen of royal omnipotence is perplexing but essential.

This essay examines courts across Eurasia as meeting points, as the hubs of pre-modern polities, where diverse elites converged and interacted with the prince. Did the interaction among these elite groups and their interplay with the ruler help to maintain cohesion in the realm? Did the ritual occasions tied to court life implicate the wider population? How can we understand the position of the ruler, always at the centre, but not necessarily in control?

Comparison often starts with establishing certain similarities; it then tends to notice marked differences, and finally tries to offer an explanation for these observations. This essay aims to push the process of comparative examination a bit further. The first section, 'Establishing similarities', recapitulates some common features of court life on a global scale that provide a basis for comparison. After this general outline, a second section on 'Examining divergences'

11 Clifford Geertz, Negara. The Theatre State in Nineteenth-Century Bali (Princeton, 1980) 130; see a thoughtful critique in Stanley J. Tambiah, Culture, Thought, and Social Action: An Anthropological Perspective (Cambridge Mass., 1985) 319-321. 
considers with greater precision four aspects setting apart courts in Europe, West and South Asia, and East Asia. While these divergences show that courtly establishments in Eurasia cannot be forced into a uniform mould, the examination suggests that, notwithstanding the variety of forms, certain shared patterns can be recognized. The third section moves to the main purpose of this essay: 'Identifying functional equivalents' of courts globally. The questions asked have a universal ring: they are relevant for most pre-modern polities and numerous examples can be found in the world-historical record. ${ }^{12}$ I consciously include African examples outside of our Eurasian perimeter and disconnected from most shared experiences. African chiefdoms, usually smaller in scale, with a limited role at best for script and print, and a marked variety of kinship systems including matrilineal descent, help to make explicit the consequences of literacy, scale, and descent. Moreover, African examples allow me to put into perspective clichés looming in the background of all East-West comparisons. The three themes singled out for discussion in the third section are all equally relevant for our book's central question: how, if at all, did these inflated households bring together the elites of extended empires and composite monarchies?

To be sure, courts never approached in practice the dominance they proclaimed in word, image, and performance. Yet in most cases, as will become clear, the court was the pivot of a world, by functioning as a meeting place, as a hub of distribution, as a stage for the ritual performance of legitimate power, and as an arena of political contestation. This essay makes explicit which functions can be found at all courts, notwithstanding the different shapes they took in various parts of Eurasia and elsewhere. Conversely, it shows that power balances at court cannot be captured in a single formula. Regional-cultural diversity, political contingency, and the huge variation in personalities on the throne forbid rigid model-making. Astute princes wielding power were succeeded by 'icon-kings' who were at the mercy of their environment-and vice versa. Contemporaries defined the alternation of integration and devolution, strength and weakness, as the essence of dynasty — and they may have a point. The rising ruler's dependents tended to turn into vested elites acting as local bosses, protected by distance and the limited means of communication. It is hardly surprising that most pre-modern political thinkers adopted a cyclical model. Their views were based on practical observation as well as on profoundly normative expectations. 


\section{Establishing Similarities}

Looking back on millennia of world history the ubiquity of dynastic rule strikes the eye. Most larger and socially differentiated polities pledged obedience to a single, usually male, figure. These leaders more often than not were able to transfer their status to close relatives: rule tended to become a family business. Heredity was one among many factors determining accession to high office, and where it prevailed, it could be organized in multiple ways. ${ }^{13} \mathrm{Nev}$ ertheless, in most cases a single kin group, or a limited number of alternating groups, proved able to monopolize paramount rulership for several generations. The predominance of power arrangements based on dynastic rule raises the question what, if anything, was shared by these very diverse polities. One common denominator of all dynastic polities was the domestic establishment comprised of the ruler with his spouses, relatives, followers, servants, and advisors. In languages across the world, we find terms for this extended household and its abode. Often, the terms indicating the dwelling and retinue of the ruler, were, by extension, also used for supreme government and sovereign power. ${ }^{14}$

Several groups can be found around all dynastic rulers: consorts, kin and children, domestic servants, soldiers, and administrators. The court, a household organized around a paramount prince, was a consistent presence in dynastic rule. Its defining element was the constant entanglement of domestic life with government, both centred on the ruler and hence necessarily overlapping in one way or another. ${ }^{15}$ Across Eurasia the domestic setup around

13 Duindam, Dynasties, chapter 2; Jack Goody, ed., Succession to High Office (Cambridge, 1966); Robbins Burling, The Passage of Power. Studies in Political Succession (New York and London, 1974).

14 See terms indicating both the spatial and social dimension: English-French $\operatorname{cour}(t)$, German Hof, Russian dvor and Persian saray; other terms refer primarily to space: castle-gatethreshold-curtain-throne: Arabic dar, qasr, qal'a; Persian darbar, sara parda, Ottoman bab-ı Hümayun, kapı, Persian $t a(k) h t$, or, conversely, to the retinue: Arabic bayt, hashiya, khassakiya. See also terms referring to specific occasions, used as pars pro toto for court life: Chinese chao (morning audience; court, dynasty); Persian diwan-i am; diwan-i khass (private-public audience hall, audience). In many court traditions terms can be found that indicate the inner and outer domains of the court, Chinese: nei-wai; Ottoman: enderunbirun; Persian: bargah-dargah. Many terms used for the court hold strong associations with sovereignty, justice, high culture, vanity, and ambition. On Abbasid terminology see Nadia Maria El Cheikh, 'Court and Courtiers: A Preliminary Investigation of Abbasid Terminology', in: Albrecht Fuess, Jan-Peter Hartung, eds., Court Cultures in the Muslim World: Seventh to Nineteenth Centuries (London and New York, 2011) 80-9o.

15 See the recent overview of courts in the period 500-1500 by Patrick J. Geary, et al., 'Courtly 
the ruler shared several characteristics. These establishments catered for common human needs, organizing activities familiar for any household: sleeping and reproduction; provisioning, eating and hospitality; devotion and ritual; mobility, security, entertainment and hunting. Princely households pursued such common activities in styles from modest to gargantuan, fitting the status of their lord and the expectations of their environments. Staffs reflecting these activities can be found at all courts, and there is some resonance even at the level of individual officeholders-doorkeepers, chamberlains, cupbearers, food tasters, physicians, tutors, bodyguards, swordbearers, quartermasters. Specific terms for staffs and officers overlap more strongly within each of the three macro-regions examined in this book: Europe, Islamicate West and South Asia, and East Asia.

All European courts included three staffs led by high noble dignitaries responsible for the chamber, the table, and the stables, with auxiliary departments catering for devotion, hunt, security, and mobility. ${ }^{16}$ All court staffs were overseen by high-placed domestic officers, the chamberlain, the steward (majordomo), and the marshal (master of the horse). These dignitaries prided themselves on their proximity to the ruler in their respective spheres of competence: the chamber, the hall, and outing beyond the perimeter of the palace. They jealously guarded the boundaries of their domains against their colleagues' infringements. While the steward in most instances developed hierarchical pre-eminence, the chamberlain and the master of the horse would never easily acknowledge his supremacy, viewing themselves as subject only to royal command. The domains of the chamberlain, steward, and marshal to some extent match the topography of other courts, with each office relating to certain spaces and responsibilities. Chamberlains watched over the inner sanctum of the ruler's bedroom, more secluded than other parts of the court, and associated with the presence of women as well as movable riches. Stewards managed the outer courtyards and halls of the palace that accommodated administrative institutions and included spaces for conspicuous hospitality as well as ritual celebrations. By extension they played a role as senior advisors and held responsibility for the logistics or 'economy' of the court. Marshals, finally,

Cultures: Western Europe, Byzantium, the Islamic world, India, China, and Japan', in: Benjamin Z. Kedar, Merry E. Wiesner-Hanks, eds., The Cambridge World History. Volume 5: Expanding Webs of Exchange and Conflict, 500 CE-1500 CE (Cambridge, 2015) chapter 7, 179-205, at 182-189.

16 Duindam, 'Royal Courts', in: Hamish Scott, ed., The Oxford Handbook of Early Modern European History. 1350-1750. Volume II: Cultures and Power (Oxford, 2015) 440-477. 
supervised the mobility of the court: stables, horses, movement, and accommodation during travel. The marshal represented the military character of the court.

These three domains - sleeping quarters, women and wealth; hospitality and government; mobility and the military — can be found elsewhere in very different institutional settings, mostly with a range of other services attached. ${ }^{17}$ Households shared many of the characteristics of the 'warband' discussed elsewhere in this book. ${ }^{18}$ The retainers following their prince could form the heart of armies, and easily shifted from the domestic to the military mode, from the palace to the tent encampment, from the banqueting hall to the battlefield. Turco-Mongol dynasties across Eurasia, whether or not they had relocated to palace compounds in urban capitals, cultivated the martial style of their nomadic forebears. European courts, into the seventeenth century, were accommodated during travels and campaigns through quartering, as was typical for armies in the same period. These were largely male and quite mobile establishments. ${ }^{19}$ Discipline and hierarchy were equally relevant in the army and at court; in Europe marshals and provosts served in both domains. However, the court can also bring to mind the well-ordered, regular rhythms and the productive capacity of the monastery rather than the dynamism of a mobile army. All courts followed a seasonal calendar of ritual-liturgical activities, and many were centres of production as well as consumption. The court tradition of the 'Sinosphere' resembled the monastic model more closely than did most West Asian, South Asian, or European traditions. ${ }^{20}$

Repeated processes of consolidation and institutionalization changed mobile households into more differentiated and sedentary establishments in all parts of Eurasia, with the possible exception of the Central Asian Steppe. Yet notwithstanding these tendencies, courts across the continent retained a fluid character, changing in numbers, composition, and often location in

17 See Geary, 'Courtly Cultures', 188 for a different division, listing aula, cubiculum, and capella - and omitting stables. The chapter contrasts the small and mobile European courts with the bigger, more differentiated and mostly sedentary establishments in Asia, a situation no longer equally valid in the period discussed here, characterized by consolidation in Europe and the rise of post-nomadic empires in West and South Asia.

18 In this volume: Jos Gommans, 'The Warband in the Making of Eurasian Empires'.

19 See Duindam, 'Royal Courts'.

20 In this volume, Peter Rietbergen, 'Not of this World ...? Religious Power and Imperial Rule in Eurasia, ca Thirteenth - ca Eighteenth Century'; Joshua E. Fogel, Articulating the Sinosphere. Sino-Japanese Relations in Space and Time (Cambridge and London, 2009). 
the course of every year according to seasonal-ritual calendars. ${ }^{21}$ The seasonal and occasional movement of people to the court contributed to its frequent transformations. All groups keen to further their interests at the heart of power were likely to come to court: to join hunting parties, banquets, and rituals; to present reports to their superiors and await appointment to new offices according to settled administrative routines; to contact other elites to forge alliances; or to seek redress and support from the ruler and his advisors. Great ephemeral solemn or festive shows recurred in the annual rhythm of the court and attracted numerous participants and onlookers. Everywhere court staffs prepared special occasions, during which the shape and the composition of the court would change substantially. The court was a magnet attracting numerous groups for a variety of reasons, a core establishment that arranged its own metamorphoses, a permanent institution creating ephemeral occasions.

Courts across Eurasia fit the format of the household writ large and hence show a certain consistency in organization and personnel. Despite great variation, moreover, they all share two defining characteristics: firstly, the presence and intermingling around the court of domestic, administrative, and military elites; secondly, the persistence of ephemeral occasions alongside institutionalized routines. Moving beyond these general, initial observations, however, marked differences strike the eye-some of these will be elaborated on below.

\subsection{Inner and Outer: The Impact of Polygyny}

European travellers visiting courts in Asia thought they recognized familiar staffs and offices, and indeed often used European terminology to describe officeholders. ${ }^{22}$ Yet wherever they went, they noted with dismay or fascination the presence of numerous dynastic spouses and concubines. Nowhere did they

21 Michael G. Chang, A Court on Horseback: Imperial Touring \& the Construction of Qing Rule, 1680-1785 (Cambridge Mass., 2007).

22 See Engelbert Kaempfer, Amoenitatum exoticarum politico-physico-medicarum fasciculi $\mathrm{V}$ (Lemgo, 1712) 78-88 with the nasir translated as grand master and the mehter as chamberlain, see also Walther Hinz, ed., Engelbert Kaempfer am Hofe des persischen Grosskönigs 1684-1685 (Leipzig, 1940) 79-87 using German titles; Engelbert Kaempfer, De beschryving van Japan, behelsende een verhaal van den ouden en tegenwoordigen staat en regeering van dat ryk ... en van hunnen koophandel met de Nederlanders en de Chineesen. Benevens eene beschryving van het koningryk Siam (Amsterdam, 1729) 371-385, courtiers at 379. 
find a match for the European-Christian practice of monogamous marriage. Polygyny was the rule among dynasties globally, and monogamous marriage occurred only as a temporary exception based on the preferences of individual rulers. As a consistent practice required by tradition, monogamous marriage in ruling families did not extend beyond Byzantium and Russia, at least not before the worldwide exportation of Christian beliefs and practices. The Solomonids of Ethiopia offer the remarkable example of a Christian dynasty openly practicing polygyny. The spread of monogamy did not proceed placidly. The abolition of concubinage by the king of Congo during the conversion to Catholicism in the 149 os was hotly contested, not least by the women in the king's household —and in practice combinations of marriage and concubinage seem to have persisted here. ${ }^{23}$ Most dynasties combined concubinage with marriage: differentiating between a single empress and various levels of consorts was common in China and Japan, whereas most West and South Asian Islamicate rulers would have several higher-ranking favourites in addition to more numerous concubines. ${ }^{24}$ To be sure, European princes were not necessarily more virtuous or chaste than their Asian counterparts: the normative canon of Christianity did not in practice prevent them from engaging in extramarital liaisons. The offspring of such encounters prohibited by the church, however, as a rule were ineligible for succession. ${ }^{25}$

The combinations of polygynous marriage and concubinage at courts from Istanbul to Edo witnessed by European visitors elicited moral censure as well as sensual daydreams. Harems and odalisques figured prominently in European fantasies about the Orient, and contributed to common views of Asian courts as stagnant 'palace polities', often contrasted with dynamic European states inexorably moving towards modernity. ${ }^{26}$ These overstated contrasts have not been helpful, yet the fact remains that polygynous dynastic reproduction affected

23 John K. Thornton, 'Elite Women in the Kingdom of Kongo: Historical Perspectives on Women's Political Power', The Journal of African History 47, no. 3 (2006) 437-46o, at 441442; John K. Thornton, 'The Development of an African Catholic Church in the Kingdom of Kongo, 1491-1750', The Journal of African History 25, no. 2 (1984) 147-167, at 158-159.

24 See Keith McMahon's two volumes on women throughout Chinese dynastic history, providing rich detail and outlining gradual changes over time: Women Shall Not Rule: Imperial Wives and Concubines in China from Han to Liao (Lanham, 2013) and Celestial Women: Imperial Wives and Concubines in China from Song to Qing (Lanham, 2016).

25 See Georges Duby, Le chevalier, la femme et le prêtre. Le marriage dans la France féodale (Paris, 1981), particularly 27-59 on the clash between priests and warriors in the imposition of monogamy in France. Note the rise of the Iberian bastard-dynasties of Avis and Trastámara.

26 See Finer, History of Government, vol. I, 38 for his first brief description of the 'palace 
the spatial and institutional structures of the court. The presence at court of either a single ruling lady, or a multitude of women had a powerful impact on succession as well as on the organization of the court.

The households of male rulers in Europe included few if any women-a handful of washerwomen and sometimes singers. Women were present only in the households of female members of the ruling house: queens-regnant, spouses, dowagers, and princesses. ${ }^{27}$ In their chambers, these ladies were served by a few dozen maids, ladies-in-waiting, and senior female officeholders. However, even these queens' and princesses' households included a majority of men in all other staffs: only the chamber remained a strictly female domain. The queen's household was usually located in the same palace, with the bedrooms of king and queen meeting at the centre of two separate apartments. ${ }^{28}$ The women serving the queen would mingle with their male counterparts, gentleman-servants or chamberlains in the royal household. Levels of separation and interaction vary strongly in Europe. In the German context, and also at the Spanish-Habsburg court, the female household remained relatively secluded in its own compartment of the palace, guarded by female officeholders chaperoning all contacts with males. The repeated issuing of regulations for the Frauenzimmer, a German term indicating both the women and their location, suggests that the ladies at times refused to comply. The BurgundianFrench-Italian court styles allowed more movement to women and did not drastically curtail the contact between men and women. Visiting the Burgundian court in 1477, the Habsburg heir and future emperor Maximilian noted to his surprise that: '... Women were not confined during day or night, and the whole house is full of young ladies ... who are allowed to walk around everywhere. ${ }^{29}$ While there were marked differences in tradition, at all courts women and men were allowed to mix at certain moments; also, queens and their female following formed part of court ceremony and public activity. The Frauenzim-

polity' under which he also grouped 'absolutist' European kingdoms, including Louis XIv's France.

27 Katrin Keller, Hofdamen: Amtsträgerinnen im Wiener Hofstaat des 17. Jahrhunderts (Vienna, 2005); Nadine Akkerman and Birgit Houben, eds., The Politics of Female Households: Ladies-in-Waiting across Early Modern Europe (Leiden and Boston, 2013); Jan Hirschbiegel and Werner Paravicini, eds., Das Frauenzimmer: Die Frau bei Hofe in Spätmittelalter und früher Neuzeit (Stuttgart, 200o).

28 Dowagers more often lived in separate residences.

29 Victor Felix von Kraus, ed., Maximilians I vertraulicher Briefwechsel mit Sigmund Prüschenk Freiherr zu Stettenberg nebst einer Anzahl zeitgenössischer Briefe (Innsbruck, 1875) 28. I thank Kim Ragetli for bringing this quote to my attention. 
mer was never wholly isolated, and it was increasingly integrated into court life during the early modern age. Numbers of women at court, moreover, remained limited.

Wherever dynastic reproduction was based on polygyny, many women were present-although harems rarely reached the astronomical figures cited by some contemporaries and recurring in the literature. ${ }^{30}$ Moreover, these women were almost always kept in seclusion, in the innermost part of the palace. This separate female division could be quite substantial. Like the European Frauenzimmer, the harem would include a hierarchy of women. Motherhood was the best claim to female authority anywhere: yet high status was shared either with the ruler's spouses where concubinage was combined with marriage, or with the most favoured concubine in the absence of marriage-as was common in the Ottoman case. ${ }^{31}$ Female relatives of the dynasty as a rule occupied the same quarters. Below these high-ranking ladies stood a more numerous group of maids, among whom only a minority were groomed for intimate relations with the prince. The number of sexually active favourites could rise to several tens during the reign of one ruler; the number of maids reached hundreds, and in exceptional cases thousands. They performed menial work and were trained in a variety of pursuits, pertaining to the tasks at hand, and related only marginally to the distant possibility of pleasing the prince. Training could include household chores, needlework, music, literature, and sometimes martial arts. ${ }^{32}$

What consequences did the presence of a harem have for the structure of the court? It required a rigidly gendered separation between the female inner court, where the prince was the only adult male who could enter, and the male outer court. At the European court the ruler's chamber was an integral part of the court's daily activities; councils met here, and guests would be received if

30 See Patricia Ebrey on this question, 'Rethinking the Imperial Harem. Why were there so many palace women?', in: Women and the Family in Chinese History (London, 2002) 177193; overstatements in Laura Betzig, 'Eusociality: From the First Foragers to the First States', Human Nature 25, no. 1 (2014) 1-5 and Betzig, 'Despotism and Differential Reproduction: A Cross-Cultural Correlation of Conflict Asymmetry, Hierarchy, and Degree of Polygyny', Ethology and Sociobiology 3, no. 4 (1982) 209-221; on the Mughal Harem see Ruby Lal, Domesticity and Power in the Early Mughal World (Cambridge, 2005) 166 and Mubarak Ali Khan, 'The Court of the Great Mughuls: Based on Persian Sources' (PhD dissertation, Bochum, 1976) 98-104.

31 Anne Walthall, ed., Servants of the Dynasty: Palace Women in World History (Berkeley and Los Angeles, 2008); Bao Hua Hsieh, Concubinage and Servitude in Late Imperial China (London, 2014).

32 Engelbert Kaempfer am Hofe des persischen Grosskönigs, 183; on women hunting, see Thomas Allsen, The Royal Hunt in Eurasian History (Philadelphia, 2006) 129-130. 
not in the bedchamber, as was common at the French court, then in any case in the preceding rooms of the apartment. While women had their own spatial domain here too, they took part in many mixed social activities and formal ceremonies. The presence of the princely apartment in the secluded harem section of the court made it easier for princes to withdraw among women and eunuchs, unapproachable for their male companions and advisors. ${ }^{33}$ The sharp divide between male and female zones at harem-based courts was most commonly guarded by 'unbearded' males: eunuchs. This castrated 'third sex' was a frequent presence at courts in Asia and Africa, where it almost always served in the capacity of harem supervisor. Following the practices of imperial Rome, monogamous Christian Byzantium, too, included eunuchs. They served not only at court, but also in the army and even in the church. Among Byzantine court eunuchs, the palace chamberlain or cubicularius came closest to the position held by eunuchs elsewhere. ${ }^{34}$ Conversely, in polygynous Japan, eunuchs were absent, and the inner-outer divide was guarded by male and female monks $($ bozu $){ }^{35}$

Eunuch guardians gained a reputation for poisonous intrigue-a cliché of court histories worldwide. One Byzantine chronicler stated that 'When a viper bit a eunuch, it was the viper that died. ${ }^{36}$ The strongly negative view of the inner court also implicated the women present. Gender bias played

33 Pal Fodor, 'Sultan, Imperial Council, Grand Vizier: Changes in the Ottoman Ruling Elite and the Formation of the Grand Vizieral Telhis', Acta Orientalia Academiae Scientiarum Hungaricae 47, no. 1/2 (1994) 67-85; Günhan Börekci and Şefik Peksevgen, 'Court and Favorites', in: Gábor Ágoston and Bruce Alan Masters, eds., Encyclopedia of the Ottoman Empire (New York, 2009) 151-154; see also Börekci's unpublished PhD dissertation 'Factions and Favorites at the Court of Sultan Ahmed I and His Immediate Predecessors' (Ohio State University, 2010).

34 On eunuchs, see Jane Hathaway, Beshir Agha: Chief Eunuch of the Ottoman Imperial Harem (London, 2005); Shaun Tougher, Eunuchs in Antiquity and Beyond (London, 2002); Shaun Tougher, The Eunuch in Byzantine History and Society (London, 2008); Kathryn M. Ringrose, The Perfect Servant, Eunuchs and the Social Construction of Gender in the Byzantine Empire (Chicago, 2003); Shih-shan Henry Tsai, The Eunuchs in the Ming Dynasty (New York, 1996); Keith Hopkins, Conquerors and Slaves (Cambridge, 1981) with a lucid chapter on the 'political power of eunuchs'.

35 Duindam, Dynasties, 197 (personal communication from Anne Walthall); on Tokugawa staffs, see Conrad D. Totman, Politics in the Tokugawa Bakufu, 160o-1843 (Cambridge Mass., 1967) appendix B, 270-277.

36 Constantine Manasses cited by Paul Magdalino, 'In Search of the Byzantine Courtier: Leo Choirosphaktes and Constantine Manasses', in: H. Maguire, ed., Byzantine Court Culture from 829 to 1204 (Washington, D.C., 1997) 141-165 at 163; on a notorious Ming eunuch, see 
a powerful role here, but in addition there was frustration among leading advisors who found themselves unable to enter, let alone control, this inner domain. Chinese literati dignitaries pointed to the dangers inherent in the ruler's presence among the eunuchs and women, and typically attributed the decline of dynasties or the debility of individual emperors to the corrupting agency of the inner court. ${ }^{37}$ Male court literati elsewhere complained about the 'meddling' of inner court agents; a blend of high-handed moral superiority, social prejudice, gender bias, and exasperation can be found among advisors in Europe whenever mistresses or lowly male servants rose to power as royal favourites. ${ }^{38}$ Yet here the high nobles serving the ruler in his domestic quarters at the same time held seats in the council or commanded armies: inner and outer were never sharply separated either in space or in personnel.

The boundaries between the domestic inner sphere of the court and its administrative outer sphere were far more emphatic from Topkapı to the Forbidden City and the shogun's castle in Edo than at any European court. ${ }^{39}$ Nevertheless, it is a commonplace of European court history to point to the gradual move of legal, financial, and more generally administrative institutions away from the domestic core of the court. These bodies, relying on record-keeping and fixed administrative routines, became sedentary while the domestic core of the court still moved around. They 'went out of court', obtaining their own buildings usually in the capital city, a situation that stimulated the formation of a separate esprit de corps, which could differ sharply from that of the typically noble courtier. In monogamous Europe the process separating the domestic and the administrative institutions of dynastic rule has been understood largely as an aspect of the consolidation and professionalization of specialized state institutions, coinciding with the emergence of a group of homines novi who never entirely mixed with the nobles dominating high court office. ${ }^{40}$

Keith McMahon, 'The Potent Eunuch: The Story of Wei Zhongxian', Journal of Chinese Literature and Culture 1 (2014) 1-28.

See e.g. McMahon, 'The Potent Eunuch'; Benjamin Elman, 'Imperial Politics and Confucian Societies in Late Imperial China: The Hanlin and Donglin Academies', Modern China 15, no. 4 (1989) 379-418.

38 For a marked example of the latter category, see Friedrich Hurter, Philipp Lang, Kammerdiener Kaiser Rudolphs II. Eine Criminal-geschichte aus dem Anfang des siebenzehnten Jahrhunderts (Schaffhausen, 1852).

See Duindam, Dynasties, for palace ground plans indicating inner and outer spheres (Topkapı, Forbidden City, and others); see note 14 above for examples of inner-outer terminology.

See a discussion of the European Robe Épée divide in J.H.M. Salmon, 'Storm over the 
Elsewhere, a similar process can be explained in part by the fact that men dominating the institutions of government could not enter the inner domesticfemale-eunuch zone of the court.

Between the fourteenth and the early nineteenth century most polities studied in this book underwent one or more phases of 'state formation', which tended to strengthen the divide between the domestic inner core and the administrative outer perimeter of the court. ${ }^{41}$ At the Chinese court, the boards and ministries had long since moved to areas clearly separated from, though adjacent to, the domestic core of the court. The remarkable clockwork of Chinese administration remained exceptional on a world scale until the innovations introduced in Europe in the later seventeenth and eighteenth centuries. Nevertheless, all bigger polities between Tokugawa Japan and England depended on government-by-paper and a group of clerks usually specializing in different tasks. Viziers (wazirs) occupied leading positions throughout West and South Asia. While they could double as army commander, they rarely if ever served simultaneously as supervisors of the inner court. Indeed, more often than not, access into this closed domain was impossible or very difficult for them. Once Ottoman Sultan Murad III had withdrawn his quarters into the Topkapı harem, he only rarely communicated with his grand viziers in person, preferring to deal with them through written reports (telhis). ${ }^{42}$ While the 'High Qing' emperors are known for their dynamic leadership and mobility, the Kangxi emperor withdrew his sleeping quarters into the inner court, allowed marginal access only to a reduced number of mostly Manchu advisors, and dealt with government in part individually, by adding comments to memorials. ${ }^{43}$ At the same time, the Qing emperors reduced the number of eunuchs and restricted their managerial responsibilities, which were taken over by unfree servants from the banner elite.

The growth and differentiation of state institutions did not take away the political relevance of the domestic establishment. The domestic core neces-

Noblesse', Journal of Modern History 53, no. 2 (1981) 242-257; on the more prestigious sword families who held high court office, see Leonhard Horowski, Die Belagerung des Thrones: Machtstrukturen und Karrieremechanismen am Hof von Frankreich 1661-1789 (Stuttgart, 2012).

41 Victor Lieberman, Strange Parallels: Southeast Asia in Global Context, c. 800-1830, 2 vols. (Cambridge, 2003) stresses convergence rather than divergence.

42 Fodor, 'Sultan, Imperial Council, Grand Vizier'.

43 Evelyn S. Rawski, The Last Emperors: A Social History of Qing Imperial Institutions (Berkeley and London, 1998) 31; Jonathan Spence, Emperor of China: Self-Portrait of K'ang-Hsi (New York, 1974). 
sarily retained its political relevance until the dynastic leader himself became politically marginalized. Only from the late-eighteenth century onwards were households relegated to the margins of political life in several European countries in a drawn-out and irregular process that gradually transferred political activity to councils and representative assemblies.

The rigid boundary surrounding a female inner sphere that also includedor bordered on-the princely sleeping quarters changed the dynamics of access. All courts knew rules restricting entry into the inner quarters, often set out in great detail tying rights of access to status. Approaching the prince in person, particularly during moments of leisure and in the intimacy of a smaller setting, not only confirmed prestige, it also brought the possibility of influencing patronage and policy decisions. Any political system predicated on the control of a single person over resources and nominations will put great emphasis on access to this person. While access did not necessarily lead to actual power, it was widely perceived to do so. ${ }^{44}$ This universal mechanism operated differently in harem-based courts, because access, and most particularly confidential access, was necessarily more restricted here. Rulers were expected to deal in one way or another with their outer-court officeholders, but it was easier for them to restrict these contacts and, at times, to evade the officeholders altogether. This conclusion should not be read as a restatement of orientalist views of 'Eastern seclusion', with sex-crazed and intoxicated despots blindly following their every whim, easy prey for eunuch servants and female consorts. There is little reason to view Asian rulers categorically as more driven by sexual appetite and erratic impulses than were their European counterparts. Mistresses were a powerful presence at many European courts, and they did have an impact on the distribution of honours as well as on decision-making. ${ }^{45}$ Moreover, the sensible and highly personal views of the Kangxi emperor, carefully pieced together by Jonathan Spence, show a perspicacity that matches or surpasses the statements left by Louis XIV and his fellow-monarchs in their

44 Forms of power as discussed in Robert D. Putnam, The Comparative Study of Political Elites (Englewood Cliffs NJ, 1976) 6-8; see also Reinhard, 'Die Nase der Kleopatra'; Engels, Geschichte der Korruption.

45 Leonhard Horowski, 'Das Erbe des Favoriten. Minister, Mätressen und Günstlinge am Hof Ludwigs XIv', in: Jan Hirschbiegel and Werner Paravicini, eds., Der Fall des Günstlings. Hofparteien in Europa vom 13. bis zum 17.Jahrhundert. 8. Symposium der Residenzenkommission der Akademie der Wissenschaften zu Göttingen (Ostfildern, 2004) 77-125; Christine Adams, “'Belle comme le jour": Beauty, Power, and the King's Mistress', French History 29, no. 2 (2015) 161-181; Mark Bryant, Sharing the Burdens of Monarchy: Louis XIV \& Mme de Maintenon, 1669-1715 (Forthcoming, Boydell \& Brewer). 
political testaments. ${ }^{46}$ Inner-court favourites can be found at many courts in Europe and Asia. Rulers at harem-based courts did not consistently withdraw in the secluded space available to them. Yet polygyny with its typically gendered palace structures made more likely the seclusion of rulers and hence tended to strengthen the position of the female confidante and the eunuch chamber servant, much to the chagrin of high officials barred from access to the inner court.

The harem underlined the male ruler's potency and fertility and had several other functions. Maids and potential concubines, whose training as a rule included needlework, served as a workforce, particularly for luxury textile production. Courts in Asia were known for their workshops and luxury production, partly in the hands of women. ${ }^{47}$ The presence of a large number of women indicated not only male prowess and dynastic power, but also represented and created wealth.

Did polygyny prevent women from holding paramount power? Between 1400 and 1800 queens regnant seem to have been an exception found mostly in Europe-several times in England, Iberia, Scandinavia, Central Europe, and Russia, and incidentally elsewhere. In the Holy Roman Empire and in France women were barred from the throne-they were present as queen-consorts and empress-consorts, but never as full sovereigns. The same can be said for the Ottomans, Mughals, and Safavids, where paramount power was male in principle, and only in case of the absence of mature male successors temporarily left in the hands of women. In China, apart from the reign of Tang Empress Wu Zetian, no woman ever formally was the sovereign ruler, whereas Korea

46 Spence, Emperor of China. See lifewriting by other rulers: Babur, The Baburnama: Memoirs of Babur, Prince and Emperor, trans. Wheeler M. Thackston (New York and Oxford, 1996); David O'Connell, The Teachings of Saint Louis: A Critical Text (Chapel Hill, 1972); Louis XIV, Mémoires, suivis de Manière de montrer les jardins de Versailles, Joël Cornette, ed. (Paris, 2007); Heinz Duchhardt, ed., Politische Testamente und andere Quellen zum Fürstenethos der frühen Neuzeit (Darmstadt, 1987).

47 See several contributions in Walthall, Servants of the Dynasty; Stephen P. Blake, Shahjahanabad: The Sovereign City in Mughal India 1639-1739 (Cambridge, 1991) in many places including the conclusion where it is generalized to include Ottoman, Safavid, Chinese, and Japanese examples. See on the relatively great importance of workshops or karkhanas in the Mughal context, S.A.A. Rizvi, The Wonder that was India. Vol. II: A Survey of the History and Culture of the Indian Sub-Continent from the Coming of the Muslims to the British Conquest 1200-1700 (London, 1987) 169-170 and Faruqui, Princes of the Mughal Empire, 107-108; Engelbert Kaempfer am Hofe des persischen Grosskönigs, 117-125. 
and particularly Japan in the same period were ruled more often by women. In Tokugawa Japan two empresses reigned, under the auspices of the invariably male Shogun.

All literary traditions of rulership in Eurasia presented the rule of men as natural and preferable; where women are discussed as active rulers, they are portrayed as an aberration. Women ascended to the throne only in the absence of plausible male alternatives. Ideally their role was that of the virtuous and deferential consort, active in arranging marriage alliances for her offspring or as a merciful advocate interceding for the people with her stern companion. ${ }^{48}$ Women holding supreme power most commonly emerged as temporary traits d'union between male rulers, as dowagers representing the dynasty in the name of their minor son. Female regents occurred in most major Eurasian polities, even in staunchly patrilineal China and in the Ottoman empire, where a series of slave concubines ruled as queen-mothers (valide sultans) from the late-sixteenth to the mid-seventeenth century. These queen-mothers wielded power formally and showed it to the outside world through their patronage of the arts and beneficence. ${ }^{49}$ Conversely inner-court women could rise to prominence through the ruler's favour. Male outer-court officials reviled women in power; female rivals in the inner court were keen to replace them once the prince's interest started to fade.

The presence of women on the throne in Europe may have been facilitated by monogamy and dynastic intermarriage. Monogamy increased the frequency of succession crises; at the same time, the bloodline of women was important for dynastic legitimacy. In the absence of sons, dynastic daughters could be preferred over more distant male contenders: they represented the 'purest' blood. These considerations were irrelevant in the context of slave concubinage where women were of indifferent background.

The mixed form of descent in Europe, where the male line was predominant but the female line was always important, complicated the position of sons sired by a king and his mistress: they were disadvantaged by their contaminated blood, but at times came to power by ousting more legitimate female contenders. In the most insistently patrilineal-polygynous settings, only the bloodline of the father mattered, and the notion of bastardry was irrel-

48 For an extended study of these themes, focusing on Burgundian duchesses and their connections with cities, see Kim Ragetli's dissertation, 'Duchess between Prince and People. A Thematic Approach to the Lives, Influence and Actions of the Duchesses of Burgundy (1430-1530)' (PhD dissertation).

49 Leslie P. Peirce, The Imperial Harem: Women and Sovereignty in the Ottoman Empire (Oxford, 1993). 
evant. In combined forms of marriage and concubinage, the status of sons, and particularly their eligibility for succession, could be differentiated. Tensions between a formal queen or empress and favourite concubines, or among concubines eagerly protecting their offspring, surfaced at most polygynous courts. Dynastic princesses in Europe were of key importance for the web of intermarrying dynasties. Yet because of their alliances with princes in distant countries, queen-consorts were often seen as potentially representing the interests, mores, and wiles of foreigners. Marie-Antoinette's pejorative nickname, l'Autrichienne, emerging soon after her arrival in Versailles, reflected a common prejudice against 'foreign' queens before it acquired strong personal connotations. A marked tension surrounded princesses from the patriline elsewhere in Eurasia: it was difficult to find evenly matched mates for these women, whose supreme birth status clashed sharply with the meekness expected of a good spouse.

Polygyny and monogamy, probably the most outspoken and incontestable contrast between Asian and European courts, created different courtly set-ups. It is not easy, however, to accurately assess the consequences of this divergence among numerous other variables. Inner-outer divisions were more blurred in the European case, and it was less easy for rulers to withdraw into a closed inner circle. Dynastic intermarriage implied the presence of high-status women, yet it did not usually grant these prestigious ladies an active political role. The overall resonance in normative judgements on women and their appropriate roles suggests we should not overrate the impact of this difference.

\subsection{The Dynasty: Succession, Competition, and Collaterals}

Contrasting modes of reproduction had a major impact on the forms of succession, the place of younger brothers and their descendants (collateral lines), and the form of dynasties. In China, collateral descendants of the staunchly patrilineal ruling houses formed a reservoir of princes who could be adopted into the main line to maintain dynastic continuity. ${ }^{50}$ The same strategy was adopted by the Japanese emperors as well as by the Tokugawa shoguns. These collaterals and their descendants, however, were not as a rule close to power, and although there are examples of rebellion and cases of successful usurpation, circulation of the supreme dignity was never the intention or common practice. A group

$5^{\circ}$ John W. Chaffee, Branches of Heaven: A History of the Imperial Clan of Sung China (Cambridge Mass., 1999); specifically on the crises generated by adoption under the Ming: Carney T. Fisher, The Chosen One. Succession and Adoption in the Court of Ming Shizong (Sydney etc., 1990). 
of collateral descendants of the Ming founder Zhu Yuanzhang lived in miniature copies of the imperial palace in their own fiefs, located in a wide swathe around the twin capitals of Beijing and Nanjing. Initially the princes served as the supreme layer of military nobility, but Zhu Yuanzhang became increasingly wary and introduced some restrictions. ${ }^{51}$ The Yongle emperor, one of the founder's sons who grabbed power by dethroning the founder's ruling grandson, initiated a policy of control and reduction of the princes that would be intensified by his successors. A huge number of Ming princes lost their position upon the Qing conquest. Qing emperors allowed the princes of the Manchu imperial lineage (Aisin Gioro) a share in government and military command, but required their residence in Beijing and closely monitored their behaviour. The early Qing show signs of the Mongol tradition of shared sovereignty, group acclamation of the new ruler by the assembled elites, and even the possibility of competition. With the support of his grandmother, Great Dowager Empress Xiaozhuang ('Bumbutai'), the Kangxi emperor forcefully ended a regency of Manchu grandees before he consolidated power in his hands. ${ }^{52}$ Subsequently he followed Han Chinese precedent by appointing his eldest surviving son as heir apparent. After a distressing sequence of conflicts with this son, he took away the honour and changed the process of designation of an heir. Succession henceforth became flexible and secret: the ruling emperor decided which son would succeed, but confided his choice only to one or two confidants. In addition, he put the name of the successor on a piece of paper stashed in a wooden casket placed some thirty feet above the throne in the audience hall at Qianqing palace. ${ }^{53}$ Dynastic marriage, in the Qing case, mostly consolidated the strong connections within the conquest clan - which in addition to the Manchu and Mongol core included Han-Chinese loyalists.

Royals eligible for succession competed fiercely in the Safavid, Mughal, and Ottoman empires, a habit often attributed to the steppe background of these dynasties. ${ }^{54}$ In the Ottoman and Mughal contexts, fratricide decimated the

51 Richard Wang, The Ming Prince and Daoism: Institutional Patronage of an Elite (Oxford, 2012) 4-8 map and list of localities of princely fiefs.

$5^{2}$ McMahon, Celestial Women, 170-173.

53 Mark C. Elliott, Qianlong. Son of Heaven, Man of the World (New York, San Francisco, and Boston, 2009) 2; Chia Ning, 'Qingchao Huangwei Jicheng Zhidu; The Institution of Qing Throne Succession (review)', China Review International 14, no. 1 (2007) 280-288; Patricia B. Ebrey, 'Succession to High Office: The Chinese Case', in: David Olson and Michael Cole, eds., Technology, Literacy, and the Evolution of Society: Implications of the Work of Jack Goody (Mahwah, 2006) 49-71.

54 See my critical discussion of the notion of 'bloody tanistry' in Dynasties, 138-139. 
collateral lines that had become so plentiful in China and Japan. In every generation the battle started anew, and it tended to leave few or no male collaterals. Daughters from the patriline could not rule, nor were their sons eligible for succession. ${ }^{55}$ These princesses hence could escape the bloodbath, and their marriages were important for the dynasty. The Safavids were equally combative, and in addition practiced the blinding of princes to make them ineligible for the throne. In their case, succession through the female line does not seem to have been excluded, which the sons of princesses found out to their dismay upon being blinded. Yet Safavid collaterals who eluded conflict were at times active in regional government, and one branch finally moved to serve the Mughals when the situation became too heated for them in Persia. ${ }^{56}$ Remarkably, the bloody contestation among brothers, keystone of succession in the Ottoman and Mughal cases, and frequent in Safavid Iran, gradually disappeared. Ottoman and Safavid princes were no longer sent out to govern and acquire experience: from the early decades of the seventeenth century onwards, they were kept under surveillance at court, and succession was determined by a mixture of seniority and elite kingmaking in both cases. ${ }^{57}$ The Mughals moved in the same direction a century later. The princes incarcerated at court were neutralized as a political factor, at least until they ascended the throne. This momentous change in succession practices, synchronous in the Ottoman and Safavid cases and followed a century later by the Mughals, appears to reflect primarily the consolidation of kingmaking-elites around the throne. ${ }^{58}$

Even without resorting systematically to mutual killing, royal families in monogamous Europe remained very small - a far cry from the Ming imperial lineage, estimated between 100,000-200,000 in the last years of the dynasty. ${ }^{59}$ From the later Middle Ages onwards, ruling houses intermarried rather than

55 Duindam, Dynasties, 104-105 and note 67.

56 Liesbeth Geevers, 'Safavid Cousins on the Verge of Extinction: Dynastic Centralization in Central Asia and the Bahrāmī Collateral Line (1517-1593)', Journal of the Economic and Social History of the Orient 58, no. 3 (2015) 293-326.

57 See p. 112 below, on the interregnum before the reign of Suleiman I of Persia.

58 Peirce, The Imperial Harem, 22, 91, 109 connects the changeover to the consolidation of the Ottoman empire, but this doesn't fit Mughal timing, and seems somewhat mechanical for the Ottoman and Safavid cases, where the changeover was gradual; Duindam, Dynasties, 133-137.

59 Rawski, Last Emperors, on the Qing princes as a 'lean aristocracy' and their more numerous Ming predecessors, 91-95, also note 117 on 328-329; see Chaffee, Branches of Heaven, 271275 . 
seeking alliances among their noble elites: increasingly only scions from sovereign houses were accepted as suitable marriage partners. This entailed not only the frequent admixture of a limited number of bloodlines, but also a progressively more intricate pattern of overlapping rights of succession. Constant intermarriage combined with the incidental extinction of senior lines made succession disputes inevitable. The Spanish succession overshadowed Europe during the unexpectedly long reign of the debilitated boy-king Charles II of Spain a product of dynastic inbreeding whose capability to reproduce was rightly questioned. A sickly sole heir without offspring formed the object of constant intrigues to influence his testament: this was the nightmare of dynastic power. It was imperative to have candidates for succession at home: ideally sons, if necessary younger brothers, or collaterals - the offspring of previous generations of younger brothers - and sometimes daughters or their sons. The collaterals acting as reserves for succession could, at times, turn into rebelprinces. Yet they were necessary: in the absence of local royal reserves entitled to succeed, external candidates would press their ambitions. Most European ancien régime wars were triggered by succession conflict. Dynastic claimants were located in different polities, whereas elsewhere in Eurasia they most often surfaced as internal contestants, plentiful in dynasties based on polygynous reproduction. The increasingly fixed pattern of dynastic succession in Europe may have reduced internal contestation; combined with the practice of monogamous dynastic intermarriage, it contributed actively to the semi-permanence of large-scale warfare. More than elsewhere in Eurasia, dynasty in Europe was inevitably a network of interconnected sovereign and leading noble houses.

Monogamy, dynastic intermarriage, and the proliferation of succession rights across the patchwork of smaller polities led to the rise of 'composite monarchies': one prince ruled multiple principalities, sometimes contiguous, sometimes dispersed. Rulers who obtained new territories through succession were usually bound by solemn agreements to respect regionally differentiated rights and exemptions. The Burgundian assemblage of counties and duchies was as typical for this tendency as the more impressive domains the Habsburgs acquired throughout Europe or the Mehrfachherrschaft of the Hohenzollern electors of Brandenburg. Even a nominally uniform monarchy such as France at closer inspection appears as a series of provinces integrated at different points and holding differentiated rights defining their connection to the conspicuous monarchical centre. Typically, representation took form at the level of cities and provinces before it moved to the central level. Only in England, following the Norman Conquest probably the most uniform larger polity of Europe, do we find a parliament that did not consist of representatives of regional assemblies. The problems of 'managing diversity' and differentiated rights observable for 
large-scale Asian land empires were also markedly present at the more modest scale of European composite monarchies. ${ }^{60}$

Partitions and co-rule of junior branches were far from exceptional in Europe, but primogeniture gradually became the dominant mode of succession in the course of the sixteenth and seventeenth centuries. Dynastic collaterals in Europe were ideal candidates for governorships in composite monarchies, ruling in the name of their house. As elsewhere, this practice entailed the risk of devolution and rebellion. Dynastic blood, in particular when it was combined with rights of succession, was a grave concern for all rulers. No parallel for the densely woven web of European dynastic alliances and enmities can be found in the greater empires of Eurasia. Yet everywhere, two options appear to have been available for dealing with the problem of princes: send them out to govern or command armies, or alternatively, maintain them close to the centre of power, under surveillance. ${ }^{61}$ The Ottomans, Mughals, and Safavids moved from the first to the second option; Ming China and Tokugawa Japan adopted a variant that can be seen as provincial domestication: allowing princely houses their own fiefs while restricting their freedom of manoeuvre. The Qing emperors required the imperial clan to reside around Beijing, but were willing to grant higher responsibilities to loyal princes-a policy surely more feasible because of Manchu minority rule. In Europe all variants existed. The Ottoman 'cage', used by Elias and others as a general metaphor for the position of nobles at court, was more relevant for dynastic successors than for the nobility at large. ${ }^{62}$ The French Dauphin, after the succession of two minors to the royal dignity in the seventeenth century, no longer had his own household. ${ }^{63}$ Louis XIV's brother Philippe paid for the repeated defiance of his namesake Gaston D'Orléans: notwithstanding his dignified position and wealth he did not hold leading political or military office. During the revolution and its

6o Daniel H. Nexon, The Struggle for Power in Early Modern Europe:Religious Conflict, Dynastic Empires, and International Change (Princeton, 2009).

61 Ebrey, 'Succession to High Office: The Chinese Case', 68; Pierre Mounier, 'La Dynamique des Interrelations Politiques: Le Cas du Sultanat de Zinder (Niger)', Cahiers d'études africaines 39, no. 154 (1999) 367-386 summarising on 374 Claude Tardits' introduction to Princes \& serviteurs, 9-21; see Jeroen Duindam, 'Dynasty and Elites: from Early Modern Europe to Late Imperial China', in: Liesbeth Geevers and Mirella Marini, eds., Dynastic Identity in Early Modern Europe: The Dynamics of Aristocratic Identity Formation in Comparative Perspective (London and New York, 2015) 59-84.

62 Duindam, Dynasties, 152, 210, 292.

63 This was primarily the consequence of dynastic demography, but the situation was maintained after Louis XIV for dauphins who reached maturity. 
aftermath in the nineteenth century, the Orléans were again conspicuously present, with Philippe Égalité voting for the execution of Louis XVI and LouisPhilippe taking the place of Bourbon king Charles $\mathrm{X}$ in 1830 . Louis XVI's brothers Provence and Artois, moreover, were prestigious as well as politically active, a permanent challenge for the shaky regime of their ruling sibling in the early years of the revolution. Under the Habsburgs, dynastic siblings were more often used as viceroys, governors, and commanders, a choice that can be explained in part by the emphatically 'composite' character of the Habsburg portfolio. ${ }^{64}$ At most European courts, princes with their households would form a ring of subsidiary courts around the court of their leading relative, depending to some extent on stipends provided by the state.

Polygyny and monogamy engendered different palace structures and changed the dynamics of access. Polygyny led to a very different concept of dynasty, with numerous princes growing up under the protection of their mothers. The collaterals were decimated in West and South Asia through competitive succession; they were maintained by the state coffers in surprising numbers in East Asia, though usually at a distance from political leadership. In Europe, the practice of monogamous dynastic intermarriage reduced fertility, increased mortality and hence enhanced the hazards of extinction. The European web of succession rights turned extinction into a prime cause for warfare. The familiar statement that European kingdoms were inherited whereas Asian empires were conquered is a half-truth because it underplays succession warfare in Europe. However, the fact that wars were based on succession claims presented as legitimate, did put successors under some pressure to respect the rights and privileges of their recently acquired subjects. This may have contributed to the remarkable persistence of hereditary elites in many European polities.

\subsection{The Nature of Elites: Nobles, Scholars, Slaves, and Disciples}

European royal families formed the uppermost echelon of a group characterized by hereditary status, landownership, and military service: the nobility. We commonly assume that no close parallel for this group exists in Asian polities, with the exception of Japan. Undoubtedly, recruitment and succession to high office were determined by heredity to a larger extent in Europe than in any of the other domains discussed here. Hereditary wealth and power were present

64 See ongoing work by Liesbeth Geevers, below in chapter 6 written with Marie FavereauDoumenjou, and in her 'Dynasty and State Building in the Spanish Habsburg Monarchy: The Career of Emanuele Filiberto of Savoy (1588-1624)', Journal of Early Modern History 2o, no. 3 (2016) 267-292. 
everywhere, but only here was hereditary status proclaimed as the ideal basis for power and social pre-eminence-a view that was never uncontested, but dominated in practice. Men rising through commercial wealth and government office designed fancy genealogies to conform to the standard of hereditary power. The church presented a separate structure of offices more open to the rise of commoners. However, the upper echelons of prelates were dominated by nobles, and worldly rulers gradually extended their grip on important church nominations-leaving the cardinals to papal discretion, and the lowerlevel clergy to local prelates. Pedigree surely was never enough to maintain power or acquire high office, but it made it easier to obtain benefits of all kinds: power and money tended to follow hereditary rank. From the later Middle Ages onwards, in all major European polities a noble upper echelon came into being that mixed old nobles, successful soldiers, and newly risen state servants, with the richest financiers. This new upper level of aristocrats, rising in tandem with the powers of the early modern prince, was strongly present at all courts. ${ }^{65}$ Commoners could enter the lower echelons of nobility through wealth, state service, marriage alliance, and lifestyle; yet only the extraordinarily successful could enter the upper layers of the court aristocracy.

The ca. 200-25o hereditary daimyo lords in Tokugawa Japan ruled in their own domains, yet these magnates were bound to the shogun's court in Edo through an intricate system of enforced regular presence (sankin kotai). The court-elite connection here originated in coercion and involved the permanent residence at Edo of daimyo relatives and retainers. The ongoing movement of daimyo lords with their convoys from their fiefs to Edo and back, as well as the frequent presence of these groups at Edo, had major economic and cultural consequences; it contributed to the increasing cohesion of the country. ${ }^{66}$ The Tokugawa elite was restricted to the warrior class: a rather big group with a relatively open lower echelon. Competing echelons and networks can be found within this single overarching category, rather than between different social groups or functional elites. Even in the inner court, where eunuchs were absent, lower-level members of the warrior class could rise to power as favourites. ${ }^{67}$

65 See the important forthcoming synthesis substantiating this point, Hamish Scott, Forming Aristocracy: The Reconfiguration of Europe's Nobilities, c. 1300-1750 (Forthcoming, Oxford University Press).

66 Constantine N. Vaporis, Tour of Duty: Samurai, Military Service in Edo, and the Culture of Early Modern Japan (Honolulu, 2008).

67 Totman, Politics in the Tokugawa Bakufu, 99-103; 214-217; Beatrice M. Bodart-Bailey, The Dog Shogun: The Personality and Policies of Tokugawa Tsunayoshi (Honolulu, 2006) 103127 . 
The centrality of the shogun's castle in Edo was made conspicuously clear by the progressions of the daimyo; yet the imperial court in Kyoto remained the untouchable copestone of the political edifice. The first shoguns, however, made sure that imperial patronage would be distributed through their hands only.

Following the Tang-Song changeover, the civil service examinations served as the main conduit to administrative office in China, and more generally as the main form of elite recruitment. In Late Imperial China huge numbers took the exams, yet most failed or proved unable to move to the critical second-level degree which gave access to office, let alone to the top-level third degree of the three-tiered system. ${ }^{68}$ Literati monopolized high office, and their culture permeated society. Government through the literati magistrates entailed a system of frequent movement and re-appointment based on regional reports and central evaluations. In their headquarters, the magistrates not only governed and administered justice; they also performed state rituals, following the practice of the central court. The literati magistrates were the predominant, but never the only, extensions of imperial power in the regions. The Ming empowered hereditary local chiefs in the periphery before they integrated these regions into the regular system of government. The military, too, had a strong component of heredity, with military families responsible for the defence of certain territories, particularly along the Mongol frontier. ${ }^{69}$ Under the Qing, the hereditary Manchu banners became the predominant military organization; at the same time the outer territories conquered by the dynasty were governed through a

68 Benjamin A. Elman, A Cultural History of Civil Examinations in Late Imperial China (Berkeley and Los Angeles, 200o) and the same author's 'Political, Social, and Cultural Reproduction via Civil Service Examinations in Late Imperial China', The Journal of Asian Studies 5o, no. 1 (1991) 7-28.

69 Barend Noordam, 'Military Identity, Empire and Frontier in the Late Ming Dynasty: Qi Jiguang (1528-1588) and His Service on Two Frontiers' (PhD dissertation). See Kenneth M. Swope, 'A Few Good Men: The Li family and China's Northern Frontier in the Late Ming', Ming Studies 49 (2005) 34-81, at 64, 69 underlines that other frontiers knew similar families; he criticizes the standard view that such families had been 'domesticated' (p. 68: note the familiar terminology) under and after the Yongle emperor, stressing their persistence and post-1550 strengthening. See also Frederic Wakeman Jr., The Great Enterprise. The Manchu Reconstruction of Imperial Order in Seventeenth-Century China (Berkeley, Los Angeles, and London, 1986) 23-86; on the Qing in Central Asia see Nicola Di Cosmo, 'Qing Colonial Administration in Inner Asia', The International History Review 20, no. 2 (1998) 287-309; on the gradual incorporation of local hereditary chiefs in the Chinese structure, see John E. Herman, 'Empire in the Southwest: Early Qing Reforms to the Native Chieftain System,' The Journal of Asian Studies 56, no. 1 (1997) 47-74. 
special board (Lifanyuan) granting some leeway to Mongol, Uygur, and Tibetan hereditary elites. ${ }^{70}$ In China proper civil government was organized along HanChinese traditions, now topped with a strong presence of Manchus at the highest levels. ${ }^{71}$ Heredity in office and power was present in the margins of the Ming polity; under the Qing the conquest elite and its allies held hereditary power. Yet the civil service examinations retained their primacy: recruitment through heredity was marginal in China, whereas it was dominant in Japan and Europe. ${ }^{72}$

The greater polities of West and South Asia were all governed by dynasties cultivating a Turco-Mongol background, mixing Arabic, Islamic, and Persian images in their repositories. This hotchpotch of legacies obtained a different stamp in the Ottoman, Mughal, and Safavid empires; each of these polities, moreover, changed over time. The staunchly Sunnite Ottomans combated the 'heresy' of Shi'ism cultivated by Safavid Shah Ismail and his successors. The Mughals, conquering a subcontinent with a strong Hindu presence, under Akbar developed a heterodox and personal religious creed that only under Aurangzeb conformed more closely to Islamic doctrine. Each of these empires needed to define its relationship to religious authorities; they usually controlled the appointment of judges, but they could never supervise all roles and offices held by the wider group of Islamic scholars, the 'ulama'.

Major differences marked the recruitment of political and military leadership. From the fourteenth century onwards, the Ottomans relied increasingly on the enforced 'collecting' (devshirme) of Christian slave boys in the peripheries of their empire and during military campaigns. They developed the common Islamicate practice of slave-soldiery to its most systematic form and extended it to encompass all leading military-political offices at court and in the empire at large. ${ }^{73}$ Only in the course of the seventeenth century

70 A good summary of these multiple institutions can be found online: Chia Ning, 'Lifanyuan and the Management of Population Diversity in Early Qing (1636-1795)', Max-PlanckInstitut für ethnologische Forschung Working Papers 139 (2012) www.eth.mpg.de/cms/de/ publications/working_papers/wpoizg.html.

71 R. Kent Guy, Qing Governors and Their Provinces: The Evolution of Territorial Administration in China, 1644-1796 (Seattle, 2010).

72 Joseph Esherick and Mary Backus Rankin, eds., Chinese Local Elites and Patterns of Dominance (Berkeley, 1990) differentiate in their conclusion between the social continuity of certain elites and the absence of heredity in office. They also point to strategies individual families could use to maintain their status, see a conspicuous example in Joseph Esherick, Ancestral Leaves: A Family Journey Through Chinese History (London, Berkeley, and Los Angeles, 2011). 
did this system gradually come to an end: appointees from the households of leading pashas and viziers infused the state apparatus, and locals could rise to prominence from the unprivileged 'flock' (reaya) through tax farming and military entrepreneurship. ${ }^{74}$ The other two major polities with Turco-Mongol roots moved in different ways from their relatively egalitarian and dynamic warbands to more institutionalized and hierarchical structures. The Safavids, starting with Ismail I, attracted numerous disciples through their Shi'ite charismatic religious leadership, organizing these devotee forces in artificial Qizilbash (redhat) tribes that bring to mind the Qing banners. ${ }^{75}$ Shah 'Abbas I, however, turned his back on these increasingly ambitious and querulous elites, and henceforth relied also on slave-soldiers and administrators. This new mixture did not prevent the devolution of the Safavid Shah's power in the second half of the seventeenth century. The Mughals, remarkably, never employed huge numbers of slaves for their military or administration. Competing local elites and their military forces were willing to be coopted into the successful Mughal venture, transformed by Akbar into an oiled carrousel of office (mansab), movement, and reward. The newly recruited mansabdars formed a mixed group in terms of ethnicity, religion, and status, but were all equally connected to the ruler's bounty. Akbar, like Ismail, also acted as the charismatic leader of his own brotherhood of religious disciples. Ottoman ümera, Safavid Qizilbash, and Mughal mansabdars were all rewarded for their services by the usufruct of lands temporarily granted to them.

Domestics, soldiers, and administrators can be found at all courts, but the recruitment of these functional groups and their status at court differed greatly. In Japan all servants of the shogunal establishment were recruited from the warrior class, yet the innermost circles of domestic servants and confidants

Christopher Leslie Brown and Philip D. Morgan, eds., Arming Slaves: From Classical Times to the Modern Age (New Haven, 2006).

74 Cumhur Bekar, 'The Rise of the Köprülü Family. The Reconfiguration of the Vizierial Power in the Seventeenth Century' (PhD dissertation); Metin Kunt, The Sultan's Servants: The Transformation of Ottoman Provincial Government, 1550-1650 (New York, 1983) with graphs of rise to high office around $155^{\circ}$ (34) and around $165^{\circ}$ (68). On the A'yan see Robert W. Zens, 'Provincial Powers: The Rise of Ottoman Local Notables (Ayan)', History Studies 3 , no. 3 (2011) 433-447. The land allocation system of revenue for officeholders gradually changed form because of the introduction of tax farming (iltizame) and particularly the tax farms granted for life (malikane), introduced in 1695; see Canay Şahin, 'The Rise and Fall of an Ayân Family in Eighteenth-Century Anatolia: The Caniklizâdes (17371808)' (Unpublished PhD dissertation, Bilkent University), with the general background discussed in chapter I.

See chapter 4 in this volume, Gommans, 'The Warband in the Making of Eurasian Empires'. 
were as a rule taken from the lower echelons, whereas leading daimyo lords enjoyed ceremonial access and supreme rank without holding important central office. The daimyo held substantial power in their own fiefs, but their position at the shogun's court has been compared to that of European nobles, maintaining social exclusivity (grandeur) but not as a rule wielding power (pouvoir). This comparison underrates the persistent power of noble elites in Europe, but it is not altogether wrong. Nobles held the highest social status and dominated in domestic service as well as in the army. Increasingly, however, they were forced to accept the presence of legal and financial specialists in the upper layers of government. Within a few generations, the minister or secretary changed from a servant doing the paperwork for noble executives to a principal executive in government - a leader in his own right, who, by that stage, was invariably ennobled and frequently intermarried with prominent noble houses. Nobility remained in place as the inevitable mark of elite distinction, but within the nobility many groups competed.

How did these leading groups fit into the inner-outer divide? In the Ottoman empire, slave elites dominated in the inner court as well as in the outer services, in military command, provincial government, and the central council (divan). Concubines and eunuchs were likewise commonly recruited as slaves - apparently, talented devshirme boys were sometimes selected and castrated to serve as white eunuchs overseeing the palace school. ${ }^{76}$ The principle of slave recruitment ruled all services with the exception of the Islamic scholars trained in madrasas, represented in the divan by the chief jurisconsult. Notwithstanding the shared background of the 'Sultan's slaves', the functional and spatial divide between inner and outer courts was quite unequivocal: leading outer-court servants could not enter the inner court, and depended on the intervention of their allies among the women and eunuchs of the inner court. The palace school increasingly incorporated local elites as well as slaves, and recruitment for high office also bypassed the palace by choosing candidates from among those serving in the households of leading viziers and pashas. These groups developed their power bases and gradually established a position as de facto hereditary elites. ${ }^{77} \mathrm{~A}$ sharp clash between status and actual power cannot structurally be seen at the Ottoman court, where eunuchs enjoyed a higher status than in East Asia, and all in government presented themselves as the Sultan's 'slaves'.

76 Ezgi Dikici, 'The Making of Ottoman Court Eunuchs: Origins, Recruitment Paths, Family Ties, and "Domestic Production"', Archivum Ottomanicum 30 (2013) 105-136. 
In Ming China the literati elite outdid the military elite in status as well as in political power, at least in periods of relative stability. They combined the moral high ground of European clergy or Islamic 'ulama' with a monopoly on leading state offices. While the dominance of literary refinement (wen) in Chinese culture may have been overestimated because of the powerful literati grip on history-writing, it is clear that under the Ming it was stronger than the ideal of martial excellence $(w u) .{ }^{78}$ This offers a powerful contrast with the supremacy of pedigree and prowess typical for Europe, offset only to some extent by the presence of religious and administrative elites. Literati combined the moral suasion of the clergy with the power of leading administrators, and formed an undisputed upper echelon. However, at the heart of the imperial Chinese polity, they could still be outmanoeuvred by eunuchs, the archetypical low-status insiders. The Qing reduced the numbers and political power of the eunuchs, and raised unfree servants from the conquest elite to power in the imperial household. ${ }^{79}$ Notwithstanding the strong Manchu position in the upper layers of government and the pervasive role of the conquest elite in the military, Han literati retained a powerful presence in Chinese culture and government.

Slaves, exam licentiates, and religious disciples all stepped in as non-hereditary power elites. Hereditary power remained the dominant mode in Europe, but this did not prevent the rise of outsiders. However, these social climbers hid their modest backgrounds behind impressive genealogies. In Japan, too, heredity remained a key aspect of elite legitimacy. Elsewhere in Eurasia elites did stressed their qualities and their service to the ruler rather than the hereditary status of their families. This fundamental difference, however, was surely stronger in the cultural representation of these groups than in practical terms: families everywhere sought and found ways to consolidate their lineages. ${ }^{80}$ More often than not, elites starting out as the ruler's dependents were able to strengthen their position over time and acquire hereditary status. Conversely, rulers could again turn to other groups to offset the power of consolidated

78 Noordam, 'Military Identity, Empire and Frontier'.

79 Rawski, Last Emperors, 166-171; on the gradual return of eunuchs in positions of trust see Norman A. Kutcher, 'Unspoken Collusions: The Empowerment of Yuanming yuan Eunuchs in the Qianlong Period', Harvard Journal of Asiatic Studies 70, no. 2 (2010) 449495 .

8o See Duindam, 'Dynasty and Elites'; Duindam, 'Pre-modern Power Elites: Princes, Courts, Intermediaries', in: John Higley, et al., eds., The Palgrave Handbook of Political Elites (London, 2017) 161-179. 
elites. In the final part of the third section of this essay common patterns in this ongoing contest will be examined.

\subsection{Ruler and Realm: Withdrawal versus Interaction?}

Rulers were surrounded by walls and guards-security was a grave concern, and outings demanded precautions. Yet at the same time, projecting the image of kingship was vital for most, if not for all, dynasties. How did the balance between protection and projection take shape in different parts of Eurasia? It is common to contrast 'Oriental seclusion' with European-style accessible royalty. The location of rulers' sleeping quarters in or close to harems does provide some justification for this view in terms of palace layout and access to inner quarters. Many observers have pointed out that princes in different parts of Eurasia did not show themselves in equal measure to their subjects. East Asian rulers, moreover, travelled less frequently than their peers elsewhere, and while on the road they were not usually visible to their subjects. Their route was swept clean, and any bystanders were expected to evade the view of the sovereign by bowing to the ground. In China and Japan alike, princes moved preferably in closed palanquins, if they moved at all. ${ }^{81}$ Dynastic power was present through stylized invisibility. The walls of the Forbidden City proclaimed the power of the emperor, but did not allow the wider public a view of this august person. The shogun's Chiyoda castle in Edo did not even have a big open space or wide urban alley directly leading up to its imposing gates. The emperor in Kyoto, the embodiment of hierarchical supremacy and ritual purity, was shielded from view to an even greater extent. This 'iconography of absence' was easier to implement for rulers who were not expected to act as military commanders. ${ }^{82}$ In Japan, the withdrawn and invisible emperor, uncontaminated by political activity or martial action, and the actively ruling Tokugawa

81 Anne Walthall, 'Hiding the Shoguns. Secrecy and the Nature of Political Authority in Tokugawa Japan', in: Bernhard Scheid and Mark Teeuwen, eds., The Culture of Secrecy in Japanese Religion (London, 2013) 332-356; see a more varied appraisal of the Song, Ming and Qing cases, Patricia Ebrey, 'Taking Out the Grand Carriage: Imperial Spectacle and the Visual Culture of Northern Song Kaifeng', Asia Major 12, no. 1 (1999) 33-65; David Robinson, Martial Spectacles of the Ming Court (Cambridge, Mass., 2013); Michael Chang, 'Historical Narratives of the Kangxi Emperor's Inaugural Visit to Suzhou, 1684', in: Jeroen Duindam and Sabine Dabringhaus, eds., The Dynastic Centre and the Provinces. Agents and Interactions (Leiden and Boston, 2014) 203-224.

82 On the 'iconography of absence' in Japan see Timon Screech, Shogun's Painted Culture: Fear and Creativity in the Japanese States, 1760-1829 (London, 2000). 
shoguns, represented the two roles clashing in many other traditions of rulership: monastic withdrawal and ritual propriety versus activism and prowess. This 'dual kingship', based on the long-standing presence of regents and generals usurping active rule, made possible the deification and distancing of the Japanese emperor and helps to explain the remarkable continuity in office of the imperial lineage. ${ }^{83}$

In China as well as in Japan, rituals and sacrifices took place in relative seclusion, with the emperor performing in a small circle of magistrates and servants, invisible to a wider public. ${ }^{84}$ Neither was the march of the emperor from the Forbidden City to the various altars in the city to be watched by spectators. ${ }^{85}$ Qing emperors showed themselves only incidentally to wider audiences, during special festivities and tours-yet their interaction with the public during their numerous movements may have been underemphasized in the official court records, bending reporting to conform to cultural standards. ${ }^{86}$ The dynamic Qing emperors, however, could still expect to be censured at times by remonstrating officials urging them to stay within the boundaries dictated by tradition. ${ }^{87}$ Images of the Chinese emperor did not circulate and were not intended to be made except at the behest of the emperor; the Ming code stipulated a punishment of '10o strokes of beating with the heavy stick' for anybody possessing images of the ruler. ${ }^{88}$ Coins never showed the ruler's profile, and the characters of the imperial name were forbidden. Here was a

83 Takie Sugiyama Lebra, Above the Clouds: Status Culture of the Modern Japanese Nobility (Berkeley and Los Angeles, 1995) 51; Ben-Ami Shillony, Enigma of the Emperors: Sacred Subservience in Japanese History (Folkestone, 2005) 6o-62; see a recent analysis by Kiri Paramore, 'Confucian Ritual and Sacred Kingship: Why the Emperors Did Not Rule Japan', Comparative Studies in Society and History 58, no. 3 (2016) 694-716.

84 Duindam, Dynasties, 26o.

85 On the more accessible grand occasions in Song Kaifeng, see Ebrey, 'Taking out the Grand Carriage'; particularly in the later Ming, emperors tended to withdraw, yet the Qing to some extent reversed the tendency. Geary, 'Courtly Cultures', at 196-197 seems to overstate the visibility of the Chinese emperors; the absence of the general public is underlined in James Laidlaw, 'On Theatre and Theory: Reflections on Ritual in Imperial Chinese Politics', in: Joseph Peter McDermott, ed., State and Court Ritual in China (Cambridge, 1999) 399416.

86 Chang, 'Historical Narratives'.

87 Robinson, Martial spectacles of the Ming Court; Patricia Ebrey, 'Remonstrating against Royal Extravagance in Imperial China', in: Jeroen Duindam and Sabine Dabringhaus, eds., The Dynastic Centre and the Provinces. Agents and Interactions (Leiden and Boston, 2014) 127-149; Chang, Court on Horseback.

88 Jiang Jonglin, The Great Ming Code (Seattle and London, 2005) article 184, 114. 
tradition by no means intent on broadcasting the ruler's face and fame in ways familiar to many other early modern dynasties. ${ }^{89}$

Confucian ideals of rulership underlined ritual propriety, self-improvement, and learning rather than prowess and interaction. Just rule was a consequence of personal moral rectitude rather than contact with the world. Moral righteousness and ritual propriety were safeguarded by a withdrawn style of rulership. In Christian Europe and Islamicate West and South Asia religion and justice were intertwined; the ideal of a humble and accessible ruler, far removed from daily practice at most courts, was always present in the background. ${ }^{90}$ The image of the prophet Muhammad, allowing all to approach him in the vicinity of the mosque, retained great power throughout Islamic history. ${ }^{91}$ Mughals showed the 'chain of justice' in their court paintings, suggesting the possibility of all to implore the ruler's mercy and justice. From the Abbasid to the Mamluk court, a tradition of personal princely justice, protecting simple subjects against the wrongdoings of officeholders, was cultivated. These mazalim-courts bring to mind the image of Saint Louis under the oak in the forest of Vincennes, freely communicating with commoners seeking justice. In Europe as well as in West and South Asia religious observations stressed the humility of all before god and hence were often the occasion for interaction between the prince and his subjects. ${ }^{92}$ Petitions typically were presented to kings during processions from palace to church, or to sultans during the procession to the Friday prayer.

Religious festivals combined dynastic representation with hospitality, exchange of gifts, and frequently also the awarding of new ranks and offices. The circumcisions of Ottoman princes and the Mughal viewing ceremony included, and even depended on, a notable popular participation or at least presence; the

89 There were other forms, however: stelae erected by literati, placards posted on walls by literati, and the 'village lectures' introduced by the Ming founder and continued by the Qing, see e.g. Sarah Schneewind, 'Visions and Revisions: Village Policies of the Ming Founder in Seven Phases', T'oung Pao 87, no. 4 (2001) 317-359.

9o Willem Flinterman, 'The Cult of Qalāwūn: Waqf, Memoria, and Dynasty in the Early Mamluk Sultanate, ca. 1280-1340' (PhD dissertation, Leiden University, 2017).

91 Michael Cook, 'Did the Prophet Muhammad Keep Court?', in: Albrecht Fuess, and JanPeter Hartung, eds., Court Cultures in the Muslim World: Seventh to Nineteenth Centuries (London and New York, 2011) 23-29.

92 Qiang Fang, 'Hot Potatoes: Chinese Complaint Systems from Early Times to the Late Qing (1898)', The Journal of Asian Studies 68, no. 4 (2009) 1105-1135; Maaike van Berkel, 'Abbasid Mazālim between Theory and Practice', Bulletin d'études orientales 63, Le pluralisme judiciaire dans l'Islam prémoderne (2014) 229-242; on legal pluralism in several 'imperial' traditions, see Jeroen Duindam, Jill Harries, Caroline Humfress, and Nimrod Hurvitz, eds., Law and Empire: Ideas, Practices, Actors (Leiden and Boston, 2013). 
same can be said about the outdoor Safavid festivals. In this respect they seem close to the urban processions and entries that took place in the European context. Many could watch the ruler and his retinue, usually from a distance and behind rows of guards. City corporations took an active part in performances, and the urban poor were allowed a share in the bounty. There are major differences here between individual rulers and between different periods; nevertheless there seems to be a shared logic and expectation of at least some exchange and visibility. The inner courts were never accessible to the wider public, but usually open places in front of the palace, or a first open court within the palace compound, did have a public function. The martial aspects of kingship were a necessary part of royal legitimacy in most European and West and South Asian polities. Martial duties underlined movement and connections - a military commander cannot stay behind high walls in the capital. Rulers were expected to show courage and martial skills. 'Battle luck' was the supreme sign of divine favour, present in the legends surrounding founding emperors, alongside stories about special signs on the body and remarkable celestial or natural omens. ${ }^{93}$ This powerful martial image, however, could clash

93 Shelley Hsueh-lun Chang, History and Legend:Ideas and Images in the Ming Historical Novels (Ann Arbor, 199o) on birth myths, 41-43, 170, on charisma 193; see Sarah Schneewind, A Tale of Two Melons: Emperor and Subject in Ming China (Cambridge Mass., 20o6). In the Safavid context farr-i Izadi (divine spark, divine effulgence) is often mentioned, see Kathryn Babayan, Mystics, Monarchs, and Messiahs: Cultural Landscapes of Early Modern Iran (Cambridge Mass., 2002) xxx, xxxiii, 21, 26, 132, 211; on a divine blessing or charisma (barakat) as being hereditary see 214, 295; both terms can also be found in Colin P. Mitchell, 'Am I my Brother's Keeper? Negotiating Corporate Sovereignty and Divine Absolutism in 16th-Century Turco-Iranian Politics', in: Colin P. Mitchell, ed., New Perspectives on Safavid Iran: Empire and Society (New York, 2011) 33-58, at 45-47. Persian farr was taken up by the Mughal and connected to Akbar's special religious position by Abu l-Fazl, see his Ain i Akbari, H. Blochmann, ed. (Calcutta, 1874) I, 170-175. A Turco-Mongol variant can be found in Turkish kut, fortune or battle luck, see Rhoads Murphey, Exploring Ottoman Sovereignty: Tradition, Image and Practice in the Ottoman Imperial Household, 1400-1800 (London and New York, 2008) 57; Mongol Qutlug was included in the titles of many rulers. Wahyu (divine inspiration or consent) mentioned in Soemarsaid Moertono, State and Statecraft in Old Java: A Study of the Later Mataram Period, 16th to 19th Century (Cornell, 1963) 6o-61; tuah (fortune), in Leonard Y. Andaya, '“A Very Good-Natured but AweInspiring Government”. The Reign of a Successful Queen in Seventeenth-Century Aceh', in: Elsbeth Locher-Scholten and P.J.A.N. Rietbergen, eds., Hof en Handel: Aziatische Vorsten en de voc 1620-1720 (Leiden, 2004) 59-84, at 63; wahyu and perwaba are discussed in J.J. Ras, 'Geschiedschrijving en de legitimiteit van het koningschap op Java', Bijdragen tot de Taal-, Land-en Volkenkunde 15o, no. 3 (1994) 518-538 at 536. These terms all appear related to the 
with the equally strong ideal of the righteous and just king, emulating his wisest forebears and steering clear of unnecessary bellicosity. No 'dual kingship' as practiced in Japan developed here, although some sultans would leave the battlefield to their viziers. In the course of the early modern age commanderkings became less common among European royalty, yet the connection never disappeared entirely.

Personalities complicate any straightforward typology. Demure kings and sultans can be found in Europe as well as in South and West Asia, whilst activist emperors can be found in Ming and Qing China. All Chinese first emperors, by definition, were generals and men of action. Did sultans consistently stay more distant from the urban crowd than European kings? The literary cliché of the ruler roaming through his capital, present in the Thousand and One Nights, recurred in later stories, depicting kings and emperors freely moving among their peoples. ${ }^{94}$ Safavid Shah 'Abbas I made an intriguing remark during one of his apparently frequent nocturnal excursions in Isfahan, exclaiming to a European friar: '... I am a king after my own will, and to go about in this way is to be king: not like yours, who is always sitting indoors! ${ }^{95} \mathrm{~A}$ few decades later, the Ottoman Sultan Murad IV, known for his military activism and violent disposition, appears to have inspected Istanbul at night, disciplining and punishing his people. ${ }^{96}$

Notwithstanding great diversity in personalities and regional styles, European kings and West and South Asian sultans appear to have been more visible than their East Asian fellow-rulers. ${ }^{97}$ At the same time, the reduction of the emperor's mobility and visibility that became common early in Chinese history

European concept of charisma, with its double meaning of divine election and personal magnetism.

Richard van Leeuwen, The Arabian Nights Encyclopedia (Santa Barbara, 2004) vol. 1, 201206, vol. 2, 487-489, 585-587; on Charles v, Martina Fuchs, Karl v. Eine populäre Figur? Zur Rezeption des Kaisers in deutschsprachiger Belletristik (Münster, 2002); Harlinde Lox, Van Stropdragers En de Pot Van Olen:Verhalen Over Keizer Karel (Leuven, 1999); Joan de Grieck, De heerelycke ende vrolycke daeden van keyser Carel den V. (Brussels, 1674).

95 Duindam, Dynasties, 179.

96 Nicholas Rolamb, 'A Relation of a Journey to Constantinople', translated from the Swedish and printed in Awnsham Churchill and John Churchill, eds., A Collection of Voyages and Travels: Some Now First Printed from Original Manuscripts, Others Now First Published in English: In Six Volumes with a General Preface Giving an Account of the Progress of Navigation from Its First Beginning (London, 1732) vol. 5 at 669-716, cites Murad Iv's violent wanderings on 690 and mentions Mehmed IV as imitating his illustrious forebear on 701 . See chapter 3 in this volume, Rietbergen, 'Not of this World ...?? 
gradually may have taken shape elsewhere in the course of the centuries studied here. The urban interactions common in late medieval European monarchy have been contrasted with seventeenth-century monarchs moving to rural hunting lodges, abandoning their tours through the country and their urban entries. Versailles is most often cited as the example of this development. Did all courts become more secluded over time, in a general process of consolidation, institutionalization, and distancing?

In the late sixteenth century, several princes were notorious indoor-types: Murad III, Emperor Rudolf II, and to some extent Henry III of France. Their seventeenth-century successors, Murad IV, Ferdinand II, and Henry IV respectively, were again far more outgoing. Late-seventeenth-century baroque piety entailed endless processions and rituals in which royalty mixed with the populace, though at Protestant courts the interactions may have become more subdued. Louis XIV prided himself on the accessibility of French monarchs and performed all basic rites of royalty in the early decades of his reign. The Versailles court struck visitors not because of its ceremonial aloofness: on the contrary, they were shocked by the exceptional accessibility of royals in the palace. The observation that ritual interaction with the realm declined under Louis XIV is in part simply a consequence of his remarkably long reign: the occasions for ceremonial tours were concentrated in the first decade or so of reigns. Ageing rulers, moreover, were much less drawn to mobility and frequent changes of locale. In the eighteenth century European royals abandoned many of the traditional religious ceremonies, but they respected the logic of interaction by creating new secular meeting points for somewhat broadened audiences. ${ }^{98}$

In the early eighteenth century the Ottoman sultans, after a long phase of residence in Edirne, returned to the old capital and engaged in a series of urban festivities and processions. ${ }^{99}$ The withdrawal of Safavid Shahs in the

98 Jeroen Duindam, 'The Dynastic Court in an Age of Change', in: Friedrich3oo Colloquien, Friedrich der Große und der Hof, Perspectivia (2009) http://www.perspectivia.net/ publikationen/friedrich3oo-colloquien/friedrich-hof/Duindam_Court; Derek Beales, 'Joseph II, petitions and the public sphere', in: Hamish Scott and Brendan Simms, eds., Cultures of Power in Europe During the Long Eighteenth Century (Cambridge, 2007) 249268.

99 Tülay Artan, 'Royal Weddings and the Grand Vezirate: Institutional and Symbolic Change in the Early Eighteenth Century', in: Jeroen Duindam, Tülay Artan, and Metin Kunt, eds., Royal Courts in Dynastic States and Empires: A Global Perspective (Leiden and Boston, 2011) 339-399. 
later seventeenth century does not seem to have continued under their Qajar successors. ${ }^{100}$

Styles of interaction frequently changed, depending on the individual temperament and age of rulers, on political constellations, and on gradually changing cultural precepts. One conclusion emerges clearly: in East Asia withdrawal was the predominant cultural mode of rulership, an alternative form of representation that was built on the idea of the ruler as a moral exemplar as well as on a division of labour between the paramount ruler and his more active agents. Individuals on the throne would stretch and sometimes disregard rules, but they were all constrained by these cultural expectations. In Europe as well as in West and South Asia, the ideals of rulership entailed miscellaneous but on the whole more active, interactive, and mobile styles. I see no consistent and ongoing process of withdrawal either in Europe or in West and South Asia.

3

\section{Identifying Functional Equivalents: Distribution, Ritual, Contestation}

The preceding paragraphs have outlined major variations among courts in East Asia, West and South Asia, and Europe. Monogamy and polygyny gave rise to different palace structures and patterns of access to the ruler. To some extent they defined the conditions of succession, succession strife, female power, and the understanding of dynasty. However, fratricide and contestation prevented the formation of collateral lines in West and South Asia, whereas collaterals inflated rapidly in East Asia: polygyny, apparently, was only one factor among many. From London to Edo, moreover, a tendency towards concentration of power in a single main line can be identified - collaterals were increasingly pushed aside, eliminated, or reduced to a role as passive reserve. Nevertheless, dynastic scions remained a matter of concern everywhere: they shared the ruler's special status and can be found as commanders and governors on the frontier; alternatively they were kept in check by some form of confinement at the centre. The recruitment of elites differed sharply across Eurasia, with a marked preponderance of hereditary noble-martial elites in Europe and Japan,

100 On the gradual restriction of access and movement, see Engelbert Kaempfer am Hofe des persischen Grosskönigs, 31, 63, 186-188; Rudi Matthee, Persia in Crisis: Safavid Decline and the Fall of Isfahan (London and New York, 2012) 57-59. See lively interactions described in Robert Ker Porter, Travels in Georgia, Persia, Armenia, Ancient Babylonia ... during the Years 1817, 1818, 1819, and 1820 (London, 1821) 316-336. 
mixed forms of recruitment through family ties, slavery, and religious vocation in West and South Asia, and a remarkably strong position for the civil service examinations in China, with a touch of heredity under the Ming, strengthened under the Qing conquest dynasty. In the long run the self-representation of these groups seems to have diverged more conspicuously than social practices: in each of these polities intermediary elites occupied key positions between the dynastic centre and locals. Slaves and disciples tended to turn into vested semihereditary power holders. Deferential literati magistrates exerted great powers under marginal control of the central state; while they could not transmit their office to their offspring, their lineages were able to maintain status through the centuries. In Europe, moreover, the emerging aristocracy was a mixture of old nobles and specialists who had risen in state service. Finally, the seclusion of rulers in East Asia contrasts strongly with the more interactive forms of rulership in the other parts of Eurasia, notwithstanding major regional and personal variations. Yet their absence from public view, combined with the busy traffic to the court and with their pervasive presence in culture, underlined their awesome powers.

The divergences examined in the previous paragraphs show that courts, dynasties, elites, and styles of rulership in Eurasia cannot be subsumed easily under a single, uniform category. Yet did courts in these different Eurasian settings, by and large, fulfil similar functions? Does variety of form hide functional equivalents, specific for Eurasia or perhaps even relevant for courtly setting in all continents? In this third section I include African examples to support my contention that several functions were indeed common to all courts: first, they were centres of redistribution; second they were the hub of rituals and festivities; third, they were arenas of political contestation. These functions point immediately to the centripetal potential of the court: many shared in the court's bounty, participated in its 'effervescences collectives', and moved there to obtain advantages. Did these functions strengthen the cohesion of the realm? Could the court, a household inflated to extraordinary proportions, help to bring together groups and regions under the loose umbrella of dynastic rule?

\subsection{Hospitality, Circulation, and Distribution}

Courts overstate every aspect of the household that suggests strength and wealth. The size and splendour of the royal compound or palace; the numbers of its guards and servants; the hospitality of the court's tables; the military trophies, dynastic regalia, and treasures on show or in hiding; the numbers of women: they all proclaim the special status of the ruler. However, these riches also display the court's potential for sharing and redistribution. This distributive nature of dynastic households is particularly clear in the African 
context. ${ }^{101}$ Many kingdoms can be found here where huge royal establishments maintained close connections with relatively small populations. A selection of examples, moving from West to East and South Africa, will highlight themes that can be re-examined in the Eurasian context. In the Asante federation, numerous women in the harem were given in marriage to chiefly lineages, connecting these to the ruling establishment. When King (asantehene) Prempeh returned from exile to re-establish his kingdom under British colonial control, his first measure was to restore the harem, not for his personal indulgence, but as the essential foundation for alliances and marriage exchanges. ${ }^{102}$ In Benin the three court staffs catering for the king employed people from almost every village. ${ }^{103}$ In the outer court of the palace compound of Bamoum all chiefs were entitled to food and drink. ${ }^{104}$ In Bunyoro, all crafts were represented in the palace, while court offices were vested hereditarily in particular clans. ${ }^{105}$ The harem of the Lovedu 'rain queen', a woman seen as masculine, served as a basis for wife-giving to district heads and noblemen. These sons-in-law of the queen, moreover, were expected to send their daughters to the harem, perpetuating a cycle of wife-exchange organized around the queen. ${ }^{106}$ African patterns of succession show a marked presence of contestation and diffusion. In a sizeable minority of polities, succession through the female line prohibited the accession of kings' sons, and privileged the kings' uterine brothers or sisters' sons. This 'sideways' rather than 'downwards' succession was also practised in patrilineal regions where powerful 'kingmakers' prevented the concentration of power in male primogeniture by prohibiting the succession of ruling kings' sons. The eligibles competing in 'sideways' succession needed to acquire the support of these elites, who were thus able to continuously reconfirm their kingmaking powers. In some cases, succession even circulated among a number of clans, usually sharing a single ancestor. Popular acclamation played a role; in some polities popular influence was not restricted to interregna. In the

101 Duindam, Dynasties, integrates African cases more systematically than this discussion, and includes examples from the Americas, Southeast Asia, and Polynesia.

102 Emmanuel Akyeampong, in Prempeh I, The History of Ashanti Kings and the Whole Country Itself and Other Writings by Otumfuo, Nana Agyeman Prempeh I, Emmanuel Akyeampong, et al., eds. (Oxford, 2003) 51-52.

103 Robert E. Bradbury, 'The Kingdom of Benin', in: Peter Morton-Williams, ed., Benin Studies (London and New York, 1973) 44-75.

104 Claude Tardits, Le royaume Bamoum (Paris, 1980) 58o, 6o1, 592.

105 John Beattie, Bunyoro: An African Kingdom (New York, 1960) 32.

106 E. Jensen Krige and J.D. Krige, The Realm of a Rain-queen: A Study of the Pattern of Lovedu Society (Oxford, 1943) 174-185. 
Asante federation, rulers who were seen as debauched or incompetent could face 'destoolment' (dethronement). The disturbances inherent in contested and circulating dynastic succession wreaked havoc, yet they also broadened the reach of royalty and offered an opportunity to attach elites to the throne.

These African examples suggest the impact a dynastic household could have on society through large-scale hospitality, the presence of numerous groups at court, wife exchange, and open succession. Were these patterns relevant for the larger and socially more differentiated Eurasian polities? Scale is a complicating factor here. With sparse and unreliable information in most cases, a calculation of numbers of people at court as a share of the entire population is a reasoned guess at best. Nevertheless, it is quite clear that a remarkable number of servants and consorts lived in and around the royal compounds in Dahomey and Bamoum. The estimated five to eight thousand mostly female servants of the Leopard King of Dahomey surely comprised more than one percent of the population, and for the one thousand wives and two thousand servants at court in less populous Bamoum the same can be said. In smaller African polities the percentages were probably even higher. ${ }^{107}$ Similar proportions cannot be found in the larger polities of Eurasia. At around twenty thousand persons, the late Ming court was at least three times the size of the court of the Leopard King, but as a share of a population of one hundred million, it dwindled into insignificance. Under the Qing, the reduced court and the rapidly growing population grew further apart in numerical terms. Proportions in Europe and West and South Asia stood between these extremes, but remained way below the African standards. The personal household of French king Louis XIV in 1699 numbered ca. two thousand persons; with all the households of other members of the dynasty, the totals rose to ca. five thousand. Including the military elite units connected to the household an aggregate number of ca. fifteen thousand can be accepted. ${ }^{108}$ This biggest of all European court establishments added up to less than o.1 percent of France's population of twenty million or so. The proportions in the Ottoman empire, with an estimated eleven thousand in the outer and two thousand in the inner service of Topkapı palace for a population of around twenty-five million, are roughly equivalent. 109

\footnotetext{
107 Duindam, Dynasties, 193.

108 Duindam, Vienna and Versailles; Duindam, 'Vienna and Versailles. Materials For Further Comparison and Some Conclusions', Zeitenblicke 4, no. 3 (2005) http://www.zeitenblicke .de/2005/3/Duindam/index_html.

109 Murphey, Ottoman Sovereignty, tables on 167, 171-174; on harem women see Peirce, The Imperial Harem, 122.
} 
In none of the larger polities did the share of the household in the population approach the African examples mentioned. The scale of most polities in Eurasia changed the nature of the interactions between the population at large and the dynastic centre. No direct connections were possible with the entire realm: across Eurasia there was at least one intermediate layer between local dignitaries and the court. Distance demanded the presence of intermediary elites to bridge the gap between centre and periphery. They commuted between the political heart and the provinces, as administrators involved in a carrousel of regional appointments, or as regional grandees combining local rule with sojourns at court. Also, the development of separate administrative hierarchies around the court in all major Eurasian polities appears to make the African examples less relevant. At the centre, specialized administrative services had developed and moved out of the court. Did these clerks and magistrates diminish the impact of the household? These institutions had become vital in preparing and filing paperwork for deliberation. Increasingly, their desks took over functions performed earlier by household officials, such as the handling of petitions. However, while the differentiated agencies of government were becoming more important, households still were the cockpit of political decision-making and high-level nominations.

How did the numbers of those involved in central administrative services compare to those in the households? The aggregate of local and central magistrates in Ming and Qing China has been estimated at twenty-five to thirty-five thousand, surprisingly few for the huge territory and population under imperial control. ${ }^{110}$ The magistrates together outnumbered the court, but the central

110 On numbers of magistrates see Benjamin A. Elman, 'The Social Roles of Literati in Early to Mid-Ch'ing', in: Willard J. Peterson, ed., The Cambridge History of China. Volume 9, Part 1: The Ch'ing Empire to 1800 (Cambridge, 2002) 360-427, at 384 citing 20,400 positions for licentiates in 15 oo expanding to 24,68 o in 1625; William Skinner, 'Introduction: Urban Development in Imperial China, in: G.W. Skinner, ed., The City in Late Imperial China (Stanford, 1977) 3-31, at 21 underlined the gradual decrease of magistrates as a proportion of the population since Han times; Guy, Qing Governors, stresses the strengthening of the structures of administration under the Qing $(35,43)$ but also points to the Qing emperors' efforts to weed out redundant positions $\left(5^{2}, 5^{6}\right)$. An estimated 100,0oo 'Clerks and runners' supported the magistrates in their tasks, see Charles O. Hucker, 'Governmental Organization of The Ming Dynasty', Harvard Journal of Asiatic Studies 21 (1958) 1-66 at 18; the presence of other intermediaries, such as notaries or litigation masters, in far higher numbers was underlined in a paper given by Hilde de Weerdt at the KNIR in spring 2015 . These higher numbers can also be found in Karl Wittfogel, Oriental Despotism: A Comparative Study of Total Power (New Haven and London, 1957) 307, 'The underlings', suggesting 
boards in the capital were certainly less numerous than their domestic inner court counterparts. The central 'bureaucracy' in Ludovician France, the 'six ministries', together numbered only seven to eight hundred persons, fewer than the household of the king's brother, and less than half of the royal household. Likewise the clerks servicing the divan (council) and its offices at the Ottoman court never approached in number the household staffs. ${ }^{111}$ Local officeholders and their staffs were far more numerous - yet many of these were not in the direct service of the dynasty and hence pursued different interests. Only the army, consistently employing more people than any other institution, dwarfed the numbers of the dynastic household as well as the administrative agencies, bearing witness to the lasting relevance of coercion. The relatively high numbers of the domestic setting of rule vis-à-vis the numbers of central administrators suggest that the household's potential for representation and sharing still played a role.

Most Eurasian polities were bigger and more populous than the African kingdoms mentioned here, yet in these larger-scale realms, succession, hospitality, supernumeraries in court service, and alliances through marriage and concubinage still were relevant for social cohesion. Acclamation, election, competition, and circulation occurred in Europe as well as among TurcoMongol dynasties. A new khan needed to be acclaimed by the Mongol council (quriltai); competition, we have seen, was long the rule in the Ottoman, Safavid, and Mughal empires. Munis Faruqi recently pointed out that succession strife among Mughal princes could reinvigorate Mughal powers, as long as these bloody interregna did not occur too often. ${ }^{112}$ Russian tsars, mediating between Mongol, European, and Byzantine traditions, combined hereditary succession with acclamation and designation - a mixture that remained unstable into the late eighteenth century. ${ }^{13}$ The two highest dignities in Europe, the pope and the emperor, were elective at least in theory. The imperial title circulated among a small number of houses before it became a Habsburg semimonopoly. After 1519 elections gave rise to negotiations confirming the rights of the electors-kingmakers on paper (Wahlkapitulationen) strengthening the

40,00o magistrates, 1,200,000 clerks and 500,00o runners. See also Peer Vries, State, Economy and the Great Divergence: Great Britain and China, 1680s-1850s (London and New York, 2015) 144.

111 Murphey, Ottoman Sovereignty; Duindam, 'Materials'.

112 Faruqui, Princes of the Mughal Empire.

113 Richard Wortman, "The Representation of Dynasty and "Fundamental Laws" in the Evolution of Russian Monarchy', Kritika: Explorations in Russian and Eurasian History 13, no. 2 (2012) 265-300. 
view of the empire as a shared endeavour notwithstanding the Habsburg semimonopoly. ${ }^{114}$ The brief tenure of a Wittelsbach emperor in 1742-1745, moreover, showed that there could still be a choice. Popes were elected by cardinals from among their own midst - and although Europe's leading dynasties were a potent influence during elections, they never pushed forward their own scions for the chair of St. Peter. ${ }^{115}$ Machiavelli compared papal elections to Mamluk practice, where a slave-soldier was selected from among his equals to perform the paramount role-although the Mamluks, too, at times tended towards the formation of dynasties. ${ }^{116}$ Acclamation by peers formed part of most monarchical traditions, and election remained important in Scandinavian monarchy until the sixteenth century and in Central Europe until the Habsburgs enforced heredity there. Poland, often remembered as the sole example of elective monarchy, was special because of the persistence of election into the eighteenth century and because of the huge numbers of electors present at the open-air meetings. Circulation of supreme office among a limited number of candidates was also practised in republics, most notably the Venetian and Dutch republics - the latter, at several moments in the seventeenth century, and more lastingly in the second half of the eighteenth century, moved closer to monarchical practice. However, we have seen that succession in most parts of Eurasia increasingly conformed to fixed patrilineal rules (male seniority or primogeniture).

The Seljuk vizier Nizam al-Mulk underlined in his advice to the prince that: 'Kings have always paid attention to having well-supplied tables in the mornings, so that those who come to the royal presence may find something to eat there.'17 Rulers who lacked 'magnanimity and generosity' would not only risk losing the respect of their subjects, but also invited the scorn of their fellow-rulers. While this maxim pertained to visiting elites rather than to the urban rabble, rulers could not evade cultural and religious expectations of

114 See also Barbara Stollberg-Rilinger, Des Kaisers alte Kleider: Verfassungsgeschichte und Symbolsprache im Alten Reich (Munich, 2008).

115 See chapter 3 in this volume, Rietbergen, 'Not of this World ...?'.

116 Niccolò Machiavelli, The Prince, trans. Peter Bondanella (Oxford, 2005) 70-71. On changing Mamluk succession practices, see Amalia Levanoni, "The Mamluk Conception of the Sultanate', International Journal of Middle East Studies 26, no. 3 (1994) 373-392 and more recently Angus Stewart, 'Between Baybars and Qalāwūn: Under-Age Rulers and Succession in the Early Mamlūk Sultanate', Al-Masaq 19, no. 1 (2007) 47-54; Flinterman, 'The Cult of Qalāwūn'.

117 Nizam al-Mulk, The Book of Government or Rules for Kings: The Siyar Al-Muluk or Siyasatnama of Nizam Al-Mulk, Hubert Darke, ed. (New York, 196o) 126-127. 
hospitality and almsgiving without jeopardizing their prestige. Servants at European courts were fed and clothed by their master; in addition, outsiders were invited to eat at the court's tables. Court staffs ate in hierarchically ordered shifts, with the dishes left by the higher tables being served to lesser staff, and the leftovers, finally, to be given to the urban poor. Most courts between the fifteenth and seventeenth centuries replaced board by monetary payments, which ended the widespread hospitality in the lower echelons of the household. Hospitality now was mostly restricted to prestigious groups, and charity left to the court's almoners. Only during special occasions, mostly related to religious festivals, would the urban poor be feasted by their sovereigns, in Europe as well as in West and South Asia. In Late Imperial China, the court did not accept hospitality as one of its regular responsibilities. Nevertheless, a system of granaries, soup kitchens, and tax remits operated to assuage poverty particularly after natural disasters - measures that went far beyond the potential of most rulers elsewhere in Eurasia.

The direct connections between villages and the court, cited for Benin, were possible only for courts in miniature polities-in Europe smaller German and Italian principalities come to mind, where urban shopkeepers doubled as court purveyors. ${ }^{118}$ Elsewhere, this direct nexus was important for the immediate environment of the main residence, usually the capital city, where numerous labourers and retailers depended on the court. ${ }^{119}$ Many observers connected urban wealth to the presence of a dynastic court. In the later fourteenth century the North African sage Ibn Khaldun noted that: 'Towns and cities are secondary products of royal authority ... dynasties and royal authority are absolutely necessary for the building of cities and the planning of towns ...'120 Two centuries later, Giovanni Botero claimed that: '... it is of immeasurable assistance in making a city great and magnificent if the prince resides there.'121

118 Lennart Bes, 'Imperial Servants on Local Thrones. Dynastic Politics in the Vijayanagara Successor States' (PhD dissertation) shows multiple connections around smaller SouthIndian Courts, but it is not possible to quantify these.

119 On these lower echelons of court staff see Herbert Haupt, Das Hof- und hofbefreite Handwerk im barocken Wien, 1620 bis 1770. Ein Handbuch (Innsbruck, Vienna, and Bozen, 2007); Irene Kubiska-Scharl and Michael Pölzl, Die Karrieren des Wiener Hofpersonals 1711-1765. Eine Darstellung anhand der Hofkalender und Hofparteienprotokolle (Innsbruck, Vienna, and Bozen, 2013); William Ritchey Newton, Dans l'ombre de la cour. Les baraques autour du château de Versailles. Le nouveau marché. L'hôtel de Limoges (Paris, 2015).

120 Giovanni Botero, On the Causes of the Greatness and Magnificence of Cities, Geoffrey Symcox, ed. (Toronto, Buffalo, and London, 2012) book II, chapter 12.

121 Ibn Khaldun, The Muqaddimah. An Introduction to History, Franz Rosenthal, ed. (Prince- 
Many urban centres throughout Eurasia thrived because of trade and manufacture rather than through the presence of a court; however, even in a bustling commercial centre such as London the presence of this demanding employer and avaricious consumer had major consequences. ${ }^{122}$ Other towns arose almost entirely in consequence of the ruler's presence. Madrid, Vienna, Turin, and many smaller German towns owed their position to royal courts. Metropolises such as Istanbul, Delhi, Isfahan, and Beijing were defined to a large extent by palace compounds and the ongoing traffic these attracted. In the course of the seventeenth century, the Janissaries attached to Topkapı palace became ever more involved in the guilds of Istanbul, sometimes acting as mafia-style 'protectors' of the guilds, but also serving as intermediaries voicing the complaints of the populace in the palace. ${ }^{123}$ At the French court, traditional court offices served as patrons for the Parisian trades they represented: the panetier (pantler) for bakers, the échanson (cupbearer) for wine merchants and taverners. ${ }^{124}$ Court-city relations, however, were rarely free from conflicts. In Europe, the royal household was a separate corporation, subject to its own officers only, and exempt from regular urban fiscal and judicial rules. Court staff were liable to abuse these rights to undersell local traders and publicans, a grave concern for the urban authorities. ${ }^{125}$ The presence of the court in the city, inevitably, proved a disaster for some, and a blessing for others.

ton and Oxford, 1967) 263; see Blake, Shahjahanabad: The Sovereign City, 69 on Mughal financial support of the city.

122 Robert Bucholz and Joseph P. Ward, London. A Social and Cultural History 1550-1750 (Cambridge, 2012) 101-131.

123 Cemal Kafadar, 'Janissaries and Other Riffraff of Ottoman Istanbul: Rebels Without a Cause?', in: Baki Tezcan and Karl K. Barbir, eds., Identity and Identity Formation in the Ottoman World: A Volume of Essays in Honor of Norman Itzkowitz (Madison, 2007) 113134; Eunjeong Yi, Guild Dynamics in Seventeenth-Century Istanbul: Fluidity and Leverage (Leiden and Boston, 2004); Donald Quataert, The Ottoman Empire, 1700-1922 (Cambridge, 2005) 136-139.

124 Duindam, Vienna and Versailles, 32-33, 38; on the imperial Erzämter see Duindam, 'The Habsburg Court in Vienna: Kaiserhof or Reichshof?' in: Robert Evans and Peter H. Wilson, eds., The Holy Roman Empire 1495-1806: A European Perspective (Boston and Leiden, 2012) 91-119.

125 Werner Paravicini and Jörg Wettlaufer, eds., Der Hof und die Stadt. Konfrontation, Koexistenz und Integration im Verhältnis von Hof und Stadt in Spätmittelalter und Früher Neuzeit (Ostfildern, 2006); Susanne Claudine Pils and Jan Paul Niederkorn, eds., Ein zweigeteilter Ort? Hof und Stadt in der Frühen Neuzeit (Innsbruck, 2005); Malcolm Smuts and George Gorse, eds., The Politics of Space: Courts in Europe c. 1500-1750 (Rome, 2009). For a more 
Youngsters often spent a few years at court as a stage in their education. Pages can be found at many courts. These young boys were sent by noble clients to their royal patron or by distant princes to their overlord to learn courtly manners as well as military skills. They came to court voluntarily or, alternatively, under duress as hostages ensuring the loyalty of their kincommon practice in the relations between the Russian Tsar and his Steppe tributaries. ${ }^{126}$ Noble boys in their early teens spent a few years at European courts, usually in the stable service where they were trained in horsemanship, martial exercises, and a school curriculum in addition to receiving on-the-job training as court servants. Novices competed for entry into court service, their family backgrounds evaluated by a genealogist in the prince's service. After a few years' service, pages could hope for nominations in the army, at court, or in administrative services. The pages in the Ottoman Palace School were recruited through devshirme and hence fall into a different category; yet their careers can be compared to those of pages at other courts. In the seventeenth century, with the demise of the system, local elite boys appear to have entered into the Sultan's cursus honorum from the outside, approximating the role of pages elsewhere. At the most exclusive level, young boys could serve as foster brothers of princes educated in the household, sharing the services of one wet nurse and becoming playmates - they often developed powerful friendships, undisturbed by the tensions at work between brothers within the dynasty.

Women in the harem likewise could be recruited voluntarily or through force, and as a safeguard preventing their families from rebelling. Mughal rulers married Persian and Rajput princesses, and included others as concubines in their harem without ever touching them. Akbar's harem included eleven women given in marriage by Rajput princes, underpinning their alliance with the emperor. ${ }^{127}$ In 1581 the Spanish Jesuit Father Monserrate, traveling to the Khyber Pass in a Mughal military convoy, reported the presence of several

general background see Peter Clark and Bernard Lepetit, eds., Capital Cities and their Hinterlands in Early Modern Europe (Aldershot, 1996).

126 The oath (shert), the practice of sending hostages (amanat), and the payment of tribute (yasak) were the common attributes of this relationship, see Michael Khodarkovsky, Russia's Steppe Frontier: The Making of a Colonial Empire, 1500-1800 (Bloomington, 2004) chapter 2, 46-74; Hans Voeten, 'The Kolyvan-Voskresensk Plants and the Russian Integration of Southern Siberia, $1725^{-1783}$ ' (PhD dissertation).

127 Frances H. Taft, 'Honor and Alliance: Reconsidering Mughal Rajput Marriages', in: Karine Schomer, Joan L. Erdman, and Deryck O. Lodrick, eds., The Idea of Rajasthan: Explorations in Regional Identity (Manohar, 1994) 217-241, tables at 218-220. 
women in this group. He explained that Akbar took the women '... with him in honourable custody, both as a reminder and proof of his own victorious glory, and as hostage in order to prevent any insurrection ....'128 Marriage alliances worked in two directions: Mughal princesses married 'exalted lineages' of the realm, houses worthy of a lasting connection with the Mughal overlords. ${ }^{129}$ These included Uzbek and Safavid princes, as well as members of prestigious religious families. Ottoman concubines were recruited as slaves and did not commonly represent any specific alliance or group. However, the princesses borne out of their union with the sultan consolidated the ties of the Ottoman ruling house with leading officeholders: young sultanas wedded experienced pashas and viziers, who now became sultanic in-laws (damads). The age difference and the frequency of executions among leading Ottoman state servants could lead to numerous subsequent remarriages by sultanas. ${ }^{130}$ The Qing system of recruitment of maids and women from the 'banners' organizing the military power of the conquest clan confirmed the supremacy of this small ruling elite and strengthened mutual loyalties. ${ }^{131}$ Maids recruited for the Qing harem, moreover, could expect to return to their banners after ten years of service or upon reaching their twenty-fifth year. ${ }^{132}$ Qing recruitment and retirement of maids in palace service, most of whom would never have been intimate with the emperor, approximates European practice. Here, ladies-in-waiting, or more accurately damsels-in-waiting, served the queen or princess in her chamber, before seeking to conclude a marriage alliance at court and under the patronage of the dynasty —often finding a partner among the young nobles groomed at court. While these damsels clearly did not form part of a harem, many rulers found mistresses in their ranks. This apparently motivated the 1674

128 Antonio Monserrate, The Commentary of Father Monserrate, s.J. on his Journey to the Court of Akbar, S.N. Banerjee, ed. (Oxford, 1922) 143.

129 Abu l-Fazl, The Akbar Nama of Abu-l-Fazl (History of the Reign of Akbar Including an Account of His Predecessors), H. Beveridge, ed. (New Delhi, 1973) three volumes, vol. 3, 677678; on the princesses' alliances, Lal, Domesticity and Power, 169-170; Stephen P. Blake, 'Returning the Household to the Patrimonial-Bureaucratic Empire: Gender, Succession, and Ritual in the Mughal, Safavid and Ottoman Empires', in: Peter Fibiger Bang and C.A. Bayly, eds., Tributary Empires in Global History (Basingstoke, 2011) 214-226, at 224.

130 Juliette Dumas, 'Les perles de nacre du sultanat. Les princesses ottomanes (mi-Xve - miXVIIIe siècle)' (Dissertation EHESs, Paris 2013) 125-194.

131 Rawski, Last Emperors, 131; Bao Hua Hsieh, Concubinage and Servitude in Late Imperial China.

132 Rawski, Last Emperors, 170-171, mentioning as age of entry thirteen to fifteen years. The age of retirement was lowered from thirty to twenty-five by the Yongzheng emperor. 
replacement of the young unmarried filles d'honneur at the French court by married dames du palais - a measure that did little to stop the practice. ${ }^{133}$

Servants active at courts elsewhere embodied connections with the city as well as with outlying regions. Slaves in the Palace School of Topkapı palace are now no longer seen as rootless: they cultivated their ties with home villages and families, particularly upon their graduation to office in the outer-court service. Conversely, locals could hope to crown their social ascent by obtaining a court title, a practice that seems to be reflected in the numbers of falconers (doğanci) and doorkeepers (kapucubaşı). ${ }^{134}$ Most courts knew phases of inflation of offices, with numbers of servants and officeholders expanding rapidly. Such offices tended to become honours only loosely connected to actual service. In Tokugawa Japan the old offices of the imperial palace were used as titles; in Ming and Qing China a complicated and varied system of lofty honorary titles was added to the differentiated hierarchies of soldiers and magistrates. Numbers of Mughal mansabdars multiplied from fewer than two thousand at the end of the sixteenth century to almost fifteen thousand a century later, surely another case of inflation of honours. ${ }^{135}$ In Europe court offices existed at three levels: a single, high-ranking officeholder responsible for the entire staff; a small number of servants who actually performed the daily tasks around the ruler in the chamber and at the table; and, finally, a third far more numerous layer of honorary servants who held court rank but performed service only incidentally. At the lower levels of the court hierarchy, this honorary status was awarded to labourers and purveyors, as a perk compensating for their modest wages that, moreover, often went unpaid. At higher levels of the social ladder noble honorary supernumeraries served as chamberlains, gentleman-carvers, and esquires: they could exercise responsibilities on the basis of regular job rotation, every semester or quarter, or alternatively their presence and service was required only during special occasions. These noble honorary servants did have the right to enter the court and participate in its activities. ${ }^{136}$ In their ranks, inflation was usually more rapid than among the 'actual' servants. Honorary membership was not limited to the court: financial and legal institutions of the state likewise developed a tendency to appoint 'honorary' councillors and supernumerary administrators - a pattern that would continue after the

133 See Pierre Clément, Madame de Montespan et Louis XIV: étude historique (Paris, 1868) 44; Duindam, Vienna and Versailles, 94.

134 Duindam, Dynasties, 243-244 and literature cited there.

135 Abraham Eraly, The Mughal World: Life in India's Last Golden Age (New Delhi and New York, 2007) 249.

136 Duindam, 'Royal Courts'. 
demise of monarchy. In addition, most European monarchies developed special distinctions for their leading servants in all domains: orders of chivalry that ideally maintained exclusivity by restricting the number of knighthoods.

These honorary extensions of the European court were defined by a combination that does not seem to have been present elsewhere. On the one hand, their high rank was reflected in the right of proximity to the ruler: they had access to the court, into the royal apartment. On the other hand, they were not necessarily often at court and were expected to perform services in the provinces and in the army. These honorary officers used their court rank as a trump card to outdo local rivals. The 'economy of honour' based on the court was a vital instrument for elites who used it to increase their status, while, at the same time, they heralded the power and glory of the court. Honorary officers did not necessarily double as administrative agents of the centre in the periphery: social and administrative hierarchies did not always overlap. Chinese literati, Mughal mansabdars, or Ottoman pashas do not seem to match this group: they could not, as a rule, enter into the ruler's inner domains, and their ranks were primarily defined by the administrative and military functions they performed. The daimyo in the Japanese case, holding ranks of the imperial court conferred by the shogun, and serving as local lords in their fiefs, come closer, but still seem different if only because of their limited numbers. European honorary officers formed a sizeable group at court and a dispersed but far more numerous court 'connection' in the provinces. More than the numbers of lesser servants at court, or the upper layer of leading officeholders, these extended noble connections of the court can be seen as the 'court society'. They were the typical courtiers, the social group that claimed membership of the court and enjoyed rights of access, but was mostly absent, living in city palaces or landed estates throughout the realm. They disseminated court culture and court style because it enhanced their status. By extension, the courtier was seen as the embodiment of culture per se-in Castiglione's spirited discussions and in later French and English tracts on the honnête homme and the gentleman. An exact parallel for this group cannot be found elsewhere. For two reasons, the term courtier should not be used as a universal label for any person active at court. First of all the term does not fit the lower levels of service personnel, who worked at court but were never part of 'court society'. Secondly, there is no close parallel in other regions for the European elites who held court rank and could incidentally act as domestic servitors in the ruler's presence, but were not usually at court.

There was more than honour to be distributed. Offices in government, army commands, and certain religious dignities were in the gift of the supreme ruler. Other bodies or individuals could have a say in these matters, but decisions for 
the upper-level nominations were rarely made without the consultation of the prince. At set points in the annual calendar, appointments, promotions, and relocations would be decided and announced. For many this was the moment of truth: would their assiduous orbiting of the court and its officeholders be rewarded? In her study of the small West African Mamprusi kingdom, Susan Drucker-Brown notes that 'Acquisition of royal chiefship entails long periods ... of competition during which the rival candidates regularly come from all parts of the kingdom to the capital bringing gifts to the king and elders.' The battle for preference took a polite, 'courtly' form which notably included the exchange of gifts and compliments. ${ }^{137}$ Distribution of offices and benefices forms a consistent focus of all governments; in the early modern period, it took shape primarily at court, where domestic and administrative spheres met, and access to the ruler was a key advantage. The process could attract aspirants from far beyond the perimeter of the palace and the capital.

The machinery of distributing offices, benefits, and status was as important in the Ottoman, Mughal, and Safavid empires as it was in European polities. The Ottoman system of promotions was based first on the 'graduation' of pages from the palace school, moving to offices in the inner or outer services of the palace, or to provincial government. Having exited the palace school, they could not re-enter; outer servants were barred from access into the inner court. All officeholders, however, would frequently return to the court to await evaluation and re-appointment, a process that could take months. ${ }^{138}$ The most successful could hope to become viziers or even to reach the supreme position as grand vizier. Pashas moving between their provincial assignments and the palace thus were a common feature. Much the same can be said about the Mughal mansabdars who were frequently reassigned to new places and whose rankings were subject to permanent re-evaluation, ideally in the hands of the emperor himself. The greatest mansabdars and pashas shared a Persianate court culture and were connoisseurs of music, poetry, or learning. They surely were 'courtiers' in this cultural sense, and much like the European honorary servants, they moved between centre and periphery. However, the Safavid Qizilbash, Ottoman pashas, and the Mughal mansabdars did not share the formally hereditary status of European nobles; neither did they serve as honorary domestic court officers holding the right to enter into the ruler's apartment. Like some of the grander magnates in Europe, these officeholders depending

\footnotetext{
137 S. Drucker-Brown, 'King House: The Mobile Polity in Northern Ghana', in: D. Quigley ed., The Character of Kingship (Oxford, 2005) 171-186, at 178.

138 Murphey, Ottoman Sovereignty, 131-137.
} 
on royal largesse were themselves the lords of major households, miniature courts representing their own power as well as that of their overlords.

For rulers and their advisors, the key challenge was to keep fluid and at their discretion the nominations to leading offices in government and army. The inflation of honours, so common at many courts, should not without further thought be understood as the ruler's intention and initiative. European rulers, more often than not, were keen to reduce the numbers at court, a policy that would save money and reinforce the exclusivity and status of court office. Statements about reduction abound in royal edicts; yet they proved very difficult to implement-a situation that matches the frequent calls by governments from the nineteenth century onwards for reductions of 'bureaucracy' coupled with the actual expansion of state administrations in most of this period. Many instances of rapid growth of courts in Europe-under Emperor Rudolf II, Charles I of England, Henry III, and during the regency of Anne of Austria in France in the 1640s-can be seen as a consequence of crisis rather than of strength. In some cases, it is possible to show that competing officeholders initiated the inflation: they usurped the sovereign's rights of nomination and attracted their followers to the court. ${ }^{139}$ Richelieu and Mazarin built their careers on their roles as trusted advisors as well as on their grip on the distribution of honours. These two succeeding cardinal-ministers monopolized Louis XIII's patronage and used it to construct their own networks of followers. Louis XIV broke this trend in the 166 os by sharply reducing the numbers of the court; moreover, he decided to rely on several advisors rather than on a single, foremost favourite. In his reign, however, competing leading ministers were able to promote their kin and kith to lucrative offices at court and in the state apparatus. Dynasties of high noble courtiers intermarried with the upper layers of the ministerial dynasties: this mixed group dominated office holding and the distribution of honours at the French court in the eighteenth century. ${ }^{140}$ Officeholders everywhere strove to consolidate their position and to transfer it to their offspring.

West and South Asian empires can be viewed as pyramids of households, held together by the distribution of offices and wealth from the imperial centre. The households and abodes of the great dignitaries formed miniature replicas of the paramount ruler's court. Elites were recruited, as we have seen above, in very different ways; yet they all depended not only on their performance in office, but also on their ability to act as intermediaries in the distribution of

139 On the causes of 'inflation' see Duindam, 'Royal Courts'.

140 Horowski, Belagerung des Thrones. 
honours. The potential to promote followers to high office was vital for leading groups in all polities discussed here. At times, their success at the dynastic centre or in the periphery overshadowed the powers of the ruler: Sokollu Mehmed Pasha served three sultans and himself became the de facto leader of the Ottoman empire before he was eliminated under Murad III. A century later Köprülü Mehmed Pasha was able not only to usurp the powers of the Valide Sultan and young Mehmed IV; he also achieved the remarkable feat of arranging the succession of his son as grand vizier. The successes of these two grand viziers were based on the consistent use of preferment to establish a network of followers throughout the Ottoman polity. ${ }^{141}$ Interestingly, however, these powerful men stopped short of seizing the sultanic powers for themselves: they styled themselves as servants of the realm. In the Ottoman and Safavid empires, governors residing at some distance from the capital emerged as semi-independent players. From the later years of Aurangzeb onwards, a few noble family networks dominated Mughal revenue allocation; they became the arbiters of power after Aurangzeb.

The Chinese empire with exam licentiates holding office and a numerous but marginalized dynastic clan cannot be pictured as a hierarchy of households. Princes lived in palaces and were served by households, but played no leading role as political-military leaders under the Ming and were kept on a short leash during the Qing. 'Bureaucratic' patterns of government, with a smattering and a fair share of hereditary elite power under the Ming and Qing respectively, could not operate without a substructure of friendship, loyalty, service, recommendation, and rivalry. The presence of networks of officeholders can be surmised from the literary correspondence surviving in printed compilations from the Song onwards, but the details of this pyramid of loyalty and patronage, and the way it related to competition at court, await further study. ${ }^{142}$ Even the great Qing emperors at times relied on their favourites, a process most pronounced under the Qianlong emperor, who in his final decades heaped favours and honours on his Manchu guardsman and advisor Heshen. ${ }^{143}$

141 Bekar, 'The Rise of the Köprülü Family'.

142 Beverly Bossler kindly allowed me to read two unpublished conference papers on the correspondence network of Yao Mian, suggesting patronage connections in the Song: 'Patronage and Principle in Late Southern Song: Yao Mian's Letters to Court Officials' (Conference on Middle Period History, Harvard University, June 5-8, 2014) and 'Yao Mian's Letters: The Epistolary Networks of a Late Song Literatus' (Political Communication in the Medieval World, 8oo-16oo, Rome, 27-29 May 2015).

143 On the role of favourites under High Qing emperors see Yingcong Dai, 'Broken Passage to the Summit: Nayancheng's Botched Mission in the White Lotus War', in: Jeroen Duindam 
At the same time, leading commanders and magistrates in their distant posts engaged in large-scale self-enrichment and patronized their proximates, under the cover of deference and unimpeachable integrity. ${ }^{144}$

Personal connections and loyalties, intisab and fidélités, were a necessary glue for all premodern polities. The inner cohesion of patronage networks, and even the competition among these networks, was an inescapable part of the cohesion of the realm as a whole. Yet there always lurked a critical point beyond which the tensions between competing networks at the centre or in the margins would escalate to open violence, disintegration, or even the creation of independent polities. The 'breathing' of empires, with tributaries developing into subject provinces before moving out of the empire and turning into independent polities, was a consequence of distance, limited means of communication and coercion, and the strength of regional-personal networks of loyalty. In Southeast Asia the same pattern would lead to shifting balances of power in an overarching 'galactic polity' consisting of numerous competing centres. ${ }^{145}$ Similar remarks can be made about the tendency of African 'segmentary states' to disintegrate and re-unite, or about this recurring process in the Eurasian steppe. Compared to these examples, the relative persistence of the greater empires in Eurasia as well as the smaller-scale interactive web of European dynasties attracts attention-apparently some of these consolidated polities were able to postpone the pressures of disintegration. ${ }^{146}$

and Sabine Dabringhaus, eds., The Dynastic Centre and the Provinces. Agents \& Interactions (Leiden and Boston, 2014) 49-73.

144 On the precarious balance between the lofty ideals of Chinese magistrates and the common reality of collusion see Etienne Balazs, Political Theory and Administrative Reality in Traditional China (London, 1965); on 'laws of avoidance' and offices intended to prevent collusion see Charles O. Hucker, A Dictionary of Official Titles in Imperial China (reprint; Beijing, 2008) 263 nr. 2887; 397-397 nr. 4862.

145 Stanley J. Tambiah, 'The Galactic Polity: The Structure of Traditional Kingdoms in Southeast Asia', in: Stanley A. Freed, ed., Anthropology and the Climate of Opinion (New York, 1977) 69-97. On fusion and fission, see Barbara Watson Andaya, 'Political Development between the Sixteenth and Eighteenth Centuries', in: Nicholas Tarling, ed., The Cambridge History of Southeast Asia. Volume 1: From Early Times to c. 1800 (Cambridge, 1992) 402-459, at 403; and Sunait Chutintaranond, 'Mandala, Segmentary State and Politics of Centralization in Medieval Ayudhya', Journal of the Siam Society 78, no. 1 (1990) 89-100; Claude Tardits, Princes et serviteurs du royaume (Paris, 1987) 20; Jan Vansina, 'A Comparison of African Kingdoms', Africa 32, no. 4 (1962) 324-335 at 329; Aidan Southall, 'The Segmentary State in Africa and Asia', Comparative Studies in Society and History 3o, no. 1 (1988) 52-82 at $61-63$.

146 One of the problems here is that information about losers will be more difficult to trace; 
At court all elites were permanently challenged by the possibility of favourites rising to power. ${ }^{147}$ Princes were able to promote their male and female companions through the ranks with remarkable speed. Inconspicuous, low-ranking servants attracted favour more easily than noble grandees or haughty advisors whose high rank and marked position complicated trust and friendship. Youth companions, foster brothers, wet nurses, tutors, and soldiers sharing first campaigns were likely favourites for young princes; mistresses or favourite concubines and lower servants were always potential candidates for favour. The quicker and more extreme the rise in status and influence of these favourites, the more likely was their sudden downfall. ${ }^{148}$

Established bureaucratic procedure could reduce somewhat the impact of personal loyalties; yet in the polities and period studied here, there was no consistent changeover from 'patrimonialism' to a type of government founded on equitable and straightforward procedures. Extended administrative services dealing with nominations and petitions were common in post-Tang China, were present in Tokugawa Japan, reinvigorated on the basis of older examples under the founding figures of the Ottoman, Safavid, and Mughal empires, and rapidly moved forward on the basis of late medieval practice in early modern Europe. Nowhere, however, did they displace from power the domestic circle around the ruler. ${ }^{149}$ Finally, the emerging bureaucracies, as Emperor Joseph II complained, were disposed to continue the faults of the ancien régime court: inflation and supernumeraries, competition for rank and preferment, preoc-

the 'vanished kingdoms' of history are far more numerous than the handful of lasting successful competitors, and their history often remains unwritten, see Norman Davies, Vanished Kingdoms: The History of Half-Forgotten Europe (London, 2012).

147 See among European studies: Jean Bérenger, 'Pour une enquête européenne: le problème du ministériat au Xvıre siècle', Annales. Économies, Sociétés, Civilisations 29, no. 1 (1974) 166-192; J.H. Elliott and L.W.B. Brockliss, eds., The World of the Favourite (New Haven and London, 1999); Michael Kaiser and Andreas Pečar, eds., Der zweite Mann im Staat: oberste Amtsträger und Favoriten im Umkreis der Reichsfürsten in der Frühen Neuzeit (Berlin, 2003); Jan Hirschbiegel and Werner Paravicini, eds., Der Fall des Günstlings. Hofparteien in Europa vom 13. bis zum 17. Jahrhundert. 8. Symposium der Residenzenkommission der Akademie der Wissenschaften zu Göttingen (Ostfildern, 2004).

148 Hirschbiegel and Paravicini, Fall des Günstlings, with Fall referring both to 'case' and to 'downfall'.

149 Certain sectors of government could adopt a more modern style of administrative efficiency, while others, often more prestigious and closer to the throne, retained a strongly patrimonial style, see e.g. the relative modernity of the English customs and excise from the 1670 on onwards, G.E. Aylmer, The Crown's Servants. Government and Civil Service Under Charles II, 1660-1685 (Oxford, 2002); Vries, State, Economy and the Great Divergence, 147. 
cupation with protocol, and Vielschreiberey. ${ }^{150}$ Rulers were the fountain of honour - prestige, offices, perks. Later we shall return to the question whether they could consistently use this formidable instrument to emerge as the arbiters of conflict at court and to act as conscious manipulators of social mobility. ${ }^{151}$

\subsection{Ritual}

The term ritual is notoriously vague. It can include all sorts of performances, from activities repeated daily by individuals in seclusion to exceptional moments bringing together people in shared semi-religious experiences. ${ }^{152} \mathrm{Cul}-$ tural connotations of terms such as rite, ceremony, or li (Confucian ritual propriety), moreover, vary widely. Ritual can be connected to violent popular practices as well as to sedate elite protocol in the settings of a palace or church. In 1817, Edward Bowdich described the Asante Yam custom, an extended festival bringing together the elites of the Asante federation. The traveller and official noted with dismay the lawlessness and licence in the capital Kumasi: 'neither theft, intrigue, nor assault are punishable ... but the grossest liberty prevails, and each sex abandons itself to its passions'. Bowdich also pointed to the ferocious demonstration of royal power: numerous executioners paraded '... the heads of the Kings and caboceers [headmen] whose kingdoms had been conquered.153 At the other extreme, we find the stately annual grand sacrifices at the altars of Beijing, proceeding with solemn dignity and attended only by officeholders. ${ }^{154}$ What did these very different occasions have in common?

150 See Joseph II's 1765 'Denkschrift' in Alfred von Arneth, Maria Theresia und Joseph II.: Ihre Correspondenz sammt Briefen Joseph's an seinen Bruder Leopold (Vienna, 1868) III, 335361; Peter G.M. Dickson, 'Monarchy and Bureaucracy in Late Eighteenth-Century Austria', English Historical Review 110, no. 436 (1995) 323-367, at 324 on inflation, see Joseph's 'Hirtenbrief' arguing strongly against personal preferences and conflict over rank, Harm Klueting, ed., Der Josephinismus. Ausgewählte Quellen zur Geschichte der theresianischjosephinischen Reformen (Darmstadt, 1995) 334.

151 See below, 'The Court as Arena'.

152 Jack Goody, 'Religion and Ritual: The Definitional Problem', British Journal of Sociology 12, no. 2 (1961) 141-164; and 'Against "Ritual": Loosely Structured Thoughts on a Loosely Defined Topic,' in: Sally Falk Moore and Barbara G. Myerhoff, eds., Secular Ritual (Assen, 1977) $25-35$.

153 Thomas Edward Bowdich, Mission from Cape Coast Castle to Ashantee: With a Descriptive Account of that Kingdom (London, 1873) the customs described at 226-253, quote at 226227 .

154 Laidlaw, 'On Theatre and Theory'; see also the somewhat impenetrable study by Angela 
In modern academic usage, ritual is more often used for popular practice, ceremony for court or church conventions - but in the early modern age, this distinction was absent, and I will use the terms as synonyms. ${ }^{155}$ Three aspects can be seen as typical for ritual in any context. Repetition is a necessary element. Rites are organized on the basis of a set pattern of rules or habits, and they recur regularly. Familiar, returning situations - the death of a ruler, the onset of carnival, the consecration of the host in mass, the announcement of a new election-set in movement a well-known sequence of events. These fixed patterns, in addition, have to be enacted by people: one can read about a ritual and discuss its parameters at length beforehand, but its only true measure lies in the actual performance of certain actions-whether in a tranceengendering Sufi whirling dance or in the decorous proceedings of a law court. Ritual is about performing rather than about thinking; it necessarily involves physical action and influences participants and spectators primarily through the body and the senses. The three elements of repetition, set rules, and physical enactment characterize ritual behaviour in all settings. Rituals performed by rulers share with other rituals the idea that only the correct performance will lead to the results anticipated, whereas inappropriate action can have inauspicious consequences. Rituals, in one way or another, are thought to reflect and impact relations at a higher level: between heaven and earth, between the living and the dead, between rulers, elites, and subjects. Rites can be seen as vain

Zito, Of Body and Brush: Grand Sacrifice as Text/Performance in Eighteenth-Century China (Chicago, 1997). It is important to note that blood sacrifice played a role both in African and Chinese rituals; likewise the responsibility for rain, fertility, and harvests was crucial for Chinese emperors as well as for African kings.

155 Definitions of ritual and ceremony in early modern as well as modern dictionaries show roughly the same two core meanings. A rite or ritus, the Oxford English Dictionary tells us, is '... a prescribed act or observance in a religious or other solemn ceremony'. This description neatly matches Johann Heinrich Zedler's eighteenth-century phrase on ritus as 'the order and ceremony, in religious services or other solemn occasions', Grosses vollständiges Universal-Lexikon, 64 vols. (Leipzig, 1732-1750) XXXII, 1832, see http://www .zedler-lexikon.de/. Zedler and the $O E D$ proceed with the second meaning, the rituale as a book containing rules for ceremonies. Both mention as example the 1614 Catholic Rituale Romanum. Zedler elsewhere cites the same book as Ceremoniale Romanum, underlining the interchangeability of the terms. Rite and ceremony are synonymous, as are rituale and ceremoniale. Beyond these two concrete primary meanings, however, differences emerge between early modern and modern usage. Early modern authors use ceremony in a more abstract and generalized way than they use ritual, covering dress, deportment, and manners. Modern authors, conversely, tend to use ritual more easily in an abstract way than ceremony. 
punctilio or as the heart of the matter. They have been understood as transforming the status of the performers or objects: turning a novice into a king, a child into an adolescent, an ordinary person into a vessel of divine grace. Finally, the performance of rites can create an overpowering sense of belonging, of finding one's place in an overarching harmonious and hierarchical order. Rites define and demonstrate hierarchies, and at the same time present a coherent and orderly whole.

All courts performed rituals, adhering to instructions transmitted from generation to generation by specialists. Rituals were prescribed in detail in learned writings, depicted in images, or simply remembered by frequently repeated performances. All courts cherished repositories of ritual objects-royal insignia, objects related to ancestors, relics, vessels, and substances with religiousmagical significance. Palaces included special spaces for the performance of rituals. Many court rituals adhered closely to the rhythms of everyday life: they were the embellished and expanded versions of family practices, following the seasonal calendar (summer and winter solstices, autumn and spring equinoxes), the agricultural year (ploughing, sowing, harvesting) and the liturgical calendar (religious cycles and festivals). In addition to these eminently recognizable cultural moments, all courts celebrated rituals related to dynastic events: death, burial, succession, birth, rites of passage (baptism, reaching majority, circumcision, capping), marriage, birthdays. These lifecycle markers, too, matched common experiences. Finally, ceremonies involved the establishment and confirmation of connections between rulers and peoples-election, acclamation, or coronation; urban entries, assemblies with elites of various kinds, and tours of the realm; the nomination or enfeoffment of officeholders. Diplomatic ceremonial can be seen as an extension of connection ritual: here, relationships with tributaries or distant sovereigns were confirmed. Domestic routines in the palace, and particularly the entry of outsiders into the palace compound, were usually subjected to a ritual choreography. Finally, a varying set of other habits connected to the court-civil service examinations, adjudication, hunting parties, and military parades—-showed strong ritual elements.

Most court rituals combined solemn and festive occasions, religious celebrations or sacrifices with banquets, theatrical shows, fireworks, and the like. Palaces were connected to the outer world through a sequence of gates linking inner secluded and outer courtyards to a more accessible interface between palace and city. From this point several processional routes led to altars, shrines, and tombs in the urban context or further away. Religious and cosmological models were important for the layout and orientation of palaces and processional routes: inner-outer, upper-lower, north-south, east-west, left-right, male- 
female, safety-danger, pure-corrupt, divine-human, noble-commoner, stranger-local, warrior-scholar, administration-household, old-young, work-relaxation. ${ }^{156}$ These normative and cosmological binaries cannot be compressed into the modern concepts of public and private, which tend to read the inner as private, domestic, and female, disconnected from the public, typically male political domain - a distortion that misses the essence of dynastic power, where family was crucial and the inner was the heart of power.

Court ritual has been interpreted in profoundly different ways. A pragmaticpolitical view understands it primarily as an instrument of power in the hands of the ruler and his advisors. Scholars have traditionally stressed the political potential of ritual, as one among many forms of repraesentatio maiestatis. This was the ruler's chance to overawe audiences, to enthral subjects, and convince them to bow before his authority. Kingship was 'fabricated' through ephemeral shows, performed on a stage of imposing monuments, and broadcast widely by images and artefacts. Consent and compliance were obtained by appealing to the senses and to widely shared religious-hierarchical ideals. Contemporaries well understood the power of spectacle. Louis XIV famously stated in his memoirs that:

The peoples we rule, unable to penetrate the essence of matters, usually found their judgements on what they can see at the surface ... people enjoy spectacle ... this is how we capture their hearts and minds. ${ }^{157}$

An early-eighteenth-century Lutheran German scholar reiterated the Sun King's view:

Most people ... are roused by sensual experience rather than by their wits or common sense; therefore, they are moved more by things that tickle the senses and strike the eye than by succinct and convincing reasoning ... Wonder and astonishment engender respect and awe, which lead to subjection and obedience. ${ }^{158}$

\footnotetext{
156 See e.g. Jianfei Zhu, Chinese Spatial Strategies: Imperial Beijing, 1420-1911 (London, 2012).

157 Louis XIV, Mémoires de Louis XIV pour l'instruction du Dauphin, Charles Dreyss, ed., I-II (Paris, 186o) II, 15, 368.

$15^{8}$ Johann Christian Lünig, Theatrum ceremoniale historico-politicum, oder Historisch- und politischer Schau-Platz aller Ceremonien, welche so wohl an europäischen Höfen als auch sonsten bey vielen illustren Fällen beobachtet worden (Leipzig, 1719-1720) I, 5 .
} 
Masters of ceremony carefully considered the impact of colours, positions, and sounds on the spectators. ${ }^{159}$ These statements appear to leave no doubt about the insights and motives of key participants in ceremony at least in the European context. But they do not tell the whole story. Frits Staal, in his work on Vedic rites, stated: 'ritual is pure activity, without meaning or goal.' ${ }^{160}$ Clifford Geertz famously reversed the priorities of the traditional interpretation, by arguing that 'power served pomp, not pomp power.'161 The ritual performance, Geertz contends, was far more than a trick to enthral subjects. He underlined the shared mentalities of performers and audiences, and the priority of the ritual performance over mundane political concerns. ${ }^{162}$

These contradictory views should not be seen as mutually exclusive: they represent two sides of the same coin. Rulers who deeply believed in their Godgiven role could still have a keen sense of the impact of ceremonial shows. The alternation or even unpremeditated amalgamation of these positions can be inferred from sources found throughout Eurasia. The fact that Akbar carefully timed his morning 'viewing' with sunrise, using the rays of the morning sun to increase his aura of 'divine effulgence' does not necessarily mean he did not take his exalted position seriously. 'Fabrication' could go together with engrained hierarchical mentalities and a profound belief in the semi-magical properties of kingship. This double awareness of the impact of ritual and festive cycles only augmented the burden on the king's shoulders as slips in this serious game could have major consequences in two directions: heavens and subjects.

A strictly instrumental view of ritual fails to take into account contemporaries' understanding of kingship. Rulers stood at the apex of society, at the intersection of hierarchies terrestrial and celestial. In some cases they themselves were seen as divine or as the offspring of divinity; in most cases a relationship with the supernatural and a special responsibility for the well-being of the realm were attributed to them. ${ }^{163}$ Their ritual was performed to safeguard harmony among their peoples and maintain concord between the living and their ancestors. The proper execution of ceremonies and sacrifices secured

159 Duindam, Vienna and Versailles, 183, citing a document from the Bibliothèque de L'Institut, Paris, collection Godefroy. 481: fol. 72-73.

16o Quote from Frits Staal, Ritual and Mantras: Rules Without Meaning (Delhi, 1996) 131; see also Staal, 'The Meaninglessness of Ritual', Numen 26, no. 1 (1979) 2-22.

161 Geertz, Negara, 132.

162 See for related assessments Peter Burke, 'The Performative Turn in Recent Cultural History', Medieval and Early Modern Performance in the Eastern Mediterranean 20 (2014) 541561 ; among many works by Barbara Stollberg-Rilinger particularly, Des Kaisers alte Kleider.

163 See chapter 3 in this volume, Rietbergen, 'Not of this World ...?'. 
the benevolence of celestial powers. The weight of this responsibility must have been felt to some extent by all dynastic rulers, yet it varied over time and regionally, mixing in different proportions with other ideals and practices of leadership.

The burden on the shoulders of ruling kings becomes painfully clear in descriptions of African royalty. The king's ominous powers needed to be shielded with great care: nobody should meet his gaze directly; the king's feet were never to touch the ground; kings could move only within a restricted area, transported by their dignitaries; often they spoke to others only indirectly, through a special intermediary. Harvests would be ruined, weather, seasons, and heavenly bodies put out of joint, should these rules be transgressed. ${ }^{164}$ Elements of this 'ritual kingship' can be found throughout Eurasia, but, surprisingly, the highly differentiated and large-scale Chinese empire offers the closest parallel. The ritual performances of Chinese emperors, notably the Grand Sacrifices performed at the altars of Beijing during the winter-summer solstices and the spring-autumn equinoxes, were seen as absolutely essential for the balance between heaven and earth. The emperor's ritual propriety and moral purity secured harmony, yet, conversely, the misdemeanours of the emperor, his kin, or magistrates ruling in his name could wreak havoc. They were punished by natural disasters sent by heaven — signs that could lead to as well as legitimize social upheaval.

This towering responsibility formed a key aspect of royal legitimacy and at the same time a major burden on the shoulders of rulers. After fighting his way to the throne, the Ming founder Zhu Yuanzhang feared losing the mandate because of the violence perpetrated by his sons:

People are the mandate of Heaven. He who has virtue Heaven will give it to him and people will follow. If he does not have [virtue], Heaven will withdraw [the mandate] and people will leave him. Now Zhou, Qi, Tan and Lu [Ming princes] have indiscriminately bullied and humiliated the soldiers and the people in their fiefs, will Heaven take away the mandate from them? 165

The Kangxi emperor, seen as utterly sensible by most observers, was likewise imbued with a grave sense of responsibility:

164 Suzanne Preston Blier, The Royal Arts of Africa: The Majesty of Form (London, 1998) 29.

165 Hok-lam Chan, 'Ming Taizu's Problem with His Sons: Prince Qin's Criminality and EarlyMing Politics', Asia Major, Third Series 20, no. 1 (2007) 45-103. 
From ancient times when there is error in human affairs the harmony of Heaven is affected. Perhaps there has been error in governance; I may have been found wanting in my personnel appointments ... ${ }^{166}$

Elsewhere, Kangxi argued that his '... careless handling of one item might bring harm to the whole world, a moment's carelessness damage all future generations.' ${ }^{167}$ Into the nineteenth century, Qing emperors were disposed to read natural disasters as a sign of their malfeasance, and they anxiously performed rites to secure rainfall during exceptional droughts. ${ }^{168}$ Throughout the Sinosphere the mandate was taken seriously. The view that the ruler's personal behaviour was connected to the well-being of his realm, however, was also present elsewhere. Natural disasters and strange movements of heavenly bodies everywhere gave rise to uneasy questions about the moral state of the ruler and those who did his bidding. With the correct performance of rites, rulers may have tried to convince themselves before they considered the impact on others.

It is necessary to take seriously the fundamental value contemporaries attributed to ritual as well as the instrumental uses they understood so well. Only rarely, however, do we find explicit statements of rulers and their close advisors about their ulterior motives: most sources mainly prescribe or describe at length the order of ceremonies and sacrifices. ${ }^{169}$ While it is thus difficult to establish the intentions of the main actors, it is even trickier to determine exactly how elite and more distant popular audiences perceived the performances enacted at court. Were they overawed, impressed, entertained, indifferent, critical, or maybe even hostile? Answers are problematic here, and they can be reached only by first establishing in some detail which audiences were present at specific ritual occasions - a task not feasible in this overview, and possible only in a few cases on the basis of the existing literature.

The regional differentiation described above provides a starting point. In East Asia dynastic visibility and popular interaction were limited. Notwithstanding variation over time, and from person to person, this typology can be accepted. Yet it needs to be refined, first by verifying the main actors, extras, and spectators present during any ritual. Who performed, who assisted, who watched at close range or from a distance? Inevitably, the cast varied according to the occasion, and this may have affected the style and tone of the ritual.

\footnotetext{
166 Rawski, Last Emperors, 225.

167 Spence, Emperor of China, 147.

168 Rawski, Last Emperors, 227.

169 See descriptions and interpretation in Zito, Body and Brush.
} 
Song festivities in Kaifeng were livelier and more interactive than the solemnities practised by most Ming emperors. ${ }^{170}$ Qing emperors engaged in inspection tours and organized public entries in Beijing as well as banquets for elders. In 1713 the Kangxi emperor initiated the custom of 'Thousand Elders' Banquets', inviting more than a thousand greybeards to dine in his company in the old summer palace (Yuanming Yuan) garden. In 1722 the old emperor repeated this show of hospitality, now inviting the elders to the inner sanctum: his inner-court Qianqing palace. The Qianlong emperor, always keen to show his respect for his grandfather, imitated Kangxi's initiative in 1785 and 1795 . More than three thousand elders attended the first banquet in and around Qianqing palace, while the latter was celebrated with more than five thousand elders in the imperial garden in the northernmost inner part of the Forbidden City.171 The classic rites performed in the Forbidden City and at the altars of Beijing, moreover, were not the only solemn or festive activities performed by Ming and Qing emperors. The laureates of the triennial metropolitan examinations held in the palace were also feted with a banquet. Dynastic occasions indirectly involved a wider public. Enthronements gave rise to the proclamation of amnesties: rulers started their reign with a clean slate. However, rites were not usually styled as meeting points or as moments of redistribution: they related first and foremost to the emperor's role as a sacrificer and moral exemplar. No synchronicity can be detected between the ritual cycle and the evaluation and relocation of officeholders: the ritual and administrative calendars followed separate patterns.

Qing emperors were known for the different roles they performed for different audiences: Han literati, Manchu bannermen, Mongol allies, and more distant Uyghur and Tibetan tributaries. Their ritual orientation varied from the classic Chinese rites, to Manchu shamanist rites performed in the inner court, to great hunting parties executed with Mongol allies, to Tibetan Buddhist observations with the same Mongol allies. This diversity was underlined by the use of different languages: Manchu and Chinese in the Forbidden City, complemented by Mongol, Uyghur, and Tibetan in the summer palace beyond the wall at Chengde. ${ }^{172}$ The 'multivocal' ritual styles of the Qing underscore

\footnotetext{
170 Ebrey, 'Taking Out the Grand Carriage'; Geary, 'Courtly Cultures', 196-197.

171 Zhang Min, 'Brief Discussion of the Banquets of the Qing Court', Proceedings of the Denver Museum of Natural History, series 3, no. 15 (1998) 67-71.

172 Nicola Di Cosmo, 'Manchu Shamanic Ceremonies at the Qing Court', in: Joseph P. McDermott, ed., State and Court Ritual in China (Cambridge, 1999) 352-398; also Faure and Laidlaw in the same volume; Rawski, Last Emperors, 231-263; James L. Hevia, 'Rulership and Tibetan Buddhism in Eighteenth-Century China: Qing Emperors, Lamas and Audience
} 
the need to look at specific contexts before making general statements about audiences and interactions.

East Asian dynastic rulers themselves were not as a rule exposed to public view, yet others constantly demonstrated their omnipresence. Chinese magistrates moved from the provinces to the centre to be evaluated and relocated; while Confucian precepts would censure overstated splendour, it is clear that the constant movement of great dignitaries to the palace reminded passers-by in the city about their distant overlord. The repeated progressions of daimyo lords from their fiefs to Edo and back likewise proclaimed the power of the shogun. ${ }^{173}$ Diplomatic missions moved to the dynastic centres in Edo and Beijing with great pomp and spectacle, again underlining the prerogatives of the hidden prince. Diplomats' reminiscences about the Qing emperors, moreover, show rather more interaction and ease behind the walls than an outsider might have expected. ${ }^{174}$

The ritual rhythms performed by the dynasty in seclusion were shared by the population in other ways. They themselves performed similar rituals, related to the traditional Shinto rites in Japan or to a mixture of state sacrifices with other cults in China. Moreover, the magistrates in their headquarters (yamen) mimicked the emperor's ritual performance. They even performed rituals for rain-making, a responsibility that connects Chinese emperors with the kings and chiefs of smaller-scale, scriptless African polities. ${ }^{175}$ Emperors were everywhere in folklore and religious practice, even if they were distant and untouchable as persons. ${ }^{176}$ In East Asia, ritual may have strengthened cohesion because

Rituals', in:Joëlle Rollo-Koster, ed., Medieval and Early Modern Ritual: Formalized Behavior in Europe, China, and Japan (Leiden and Boston, 2002) 279-302 at 28o; David M. Farquhar, 'Emperor as Bodhisattva in the Governance of the Ch'ing Empire', Harvard Journal of Asiatic Studies 38, no. 1 (1978) 5-34; Natalie Köhle, 'Why Did the Kangxi Emperor Go to Wutai Shan? Patronage, Pilgrimage and the Place of Tibetan Buddhism at the Early Qing Court', Late Imperial China 29, no. 1 (2008) 73-119.

173 Vaporis, Tour of Duty.

174 Duindam, Dynasties, 205.

175 On the intermingling of daoist and magical practices in the rain rituals at local levels, see Jeffrey Snyder-Reinke, Dry Spells: State Rainmaking and Local Governance in Late Imperial China (Cambridge Mass., 2009).

${ }_{17} 6$ See chapter 7 below by Richard van Leeuwen and his monograph on Narratives of Kingship in Eurasian Empires 1300-1800 (Leiden and Boston, 2017); Barend ter Haar, 'Divine Violence to Uphold Moral Values: The Casebook of an Emperor Guan Temple in Hunan Province in 1851-1852', in: Jeroen Duindam, Jill Harries, Caroline Humfress, and Nimrod Hurvitz, eds., Law and Empire: Ideas, Practices, Actors (Leiden and Boston, 2013) 314338. 
it reflected shared beliefs and practices, but it did not as a rule bring together the dynasty and the populace in a shared performance, actively creating a new connection. ${ }^{177}$

Moral-religious priorities shaped ritual in East Asia in a way that contrasts with patterns prevalent elsewhere in Eurasia, where rituals ranged from carnavalesque melées, carefully orchestrated tense meetings of contending groups, to sedate solemnities performed in seclusion. In West and South Asia interaction with the public occurred, at popular as well as at elite levels. The Ottoman, Mughal, and Safavid rulers celebrated the breaking of the fast (Id al-Fitr), a festival gradually moving through the solar year because its timing followed the Islamic lunar calendar. Each dynasty cultivated other festivities. The circumcision ceremony (sur) of princes probably formed the most conspicuous meeting point of the dynasty and its subjects in the Ottoman context. Persian New Year (nauruz) took shape in a series of festivities in the Safavid realm. The Mughals were known for several ceremonial inventions, in particular the 'viewing' ceremony (jharokha-i darshan), which allowed the public a regular glimpse of their prince. In a more secluded setting, the ceremony of the birthday 'weighing' took place. Twice every year, following the lunar Islamic and the solar calendars, rulers were weighed. Precious articles were put in the scales, ranging from jewels and gold to iron, silks, and edibles.

Court rituals here could indeed form moments for sharing and mutual rejoicing. The circumcision festivals of Ottoman princes gave rise to large outdoor banquets, scrambles for food (yaghma), numerous diversions, and the scattering of coins. During these occasions, sultans paid for the circumcision of many other boys; the city guilds performed their skills and feats for the sultan. During the Mughal weighing ceremony 'donations, or grants of pardon, are bestowed upon people of all ranks', Abu l-Fazl reported. Seventeenth-century travellers noticed the remarkable riches heaped on the scales to weigh the emperor and mentioned five days of rejoicing in the palace and the city, with fireworks displays and battles of elephants. ${ }^{178}$ The high points of the ritual calendar in West and South Asia attracted crowds, hoping to glimpse the ruler and partake in the distribution of food and the scattering of coins (nithar). This popular meeting coincided with the convergence of the leading elites around the ruler, offering their renewed statements of fealty and presenting their tribute and gifts ( piskes). The great meeting points often also included the

\footnotetext{
177 Laidlaw, 'On Theatre and Theory'.

178 Abu l-Fazl, The Ain i Akbari, H. Blochmann, ed. (Calcutta, 1873) I, 276-277; Jean de Thévenot, Voyages de Mr de Thévenot contenant la relation de l'Indostan, des nouveaux Mogols et des autres peuples \& pays des Indes (Paris, 1684) 138-140.
} 
eagerly awaited moment of nominations and relocations. For the officeholders, this was a rite of passage in a very concrete sense, which could lead to elevated office or to punishment and exile.

The highlights of European courts included a roughly similar mixture. Many ceremonies featured forms of conspicuous hospitality and largesse: public banquets with wine-spouting fountains, the scattering of coins (jetons), and roasts left to the public. The Frankfurt coronation banquet following the election of a new emperor attracted many thousands of spectators. It traditionally ended in a wild scramble for the leftovers, a battle that usually produced more than a few casualties. ${ }^{179}$ In several of the most striking interactions with the public, kingship's magical-religious aspect was visible. The Christmas and Easter cycles entailed numerous religious meeting points of rulers and subjects, particularly during Holy Week. The re-enactment of the Last Supper on Maundy Thursday, with royalty washing the feet of twelve or thirteen poor and subsequently serving these paupers at the table turned into one of the prime ceremonies demonstrating sovereign power in Catholic Europe. ${ }^{180}$ The pious processions performed by Habsburg rulers in Brussels, Vienna, and Madrid through the liturgical year, but concentrated in Holy Week, were a powerful expression of the connections between sovereigns and subjects. ${ }^{181}$ These same customs could be found in France and in a somewhat subdued form in England. ${ }^{182}$ In these two domains, the royal touch demonstrated the wondrous powers of kings, allowing divine grace to cure sufferers of scrofula through the king's hands. The custom fell into abeyance in England under William and Mary, but was restored by Queen Anne, who performed the ritual for thousands of people until 1712 . Changing religious sensibilities led to the abolition of the practice under the Hanoverian kings of England. In France it lapsed under Louis XV of France, who gave two very different reasons for his reticence to perform the age-old custom: adultery prohibited him from taking communion and hence barred him from divine grace - and, on the other hand, modern medication made his intervention superfluous. ${ }^{183}$ Louis XVI again touched several thousands

179 Duindam, 'The Habsburg Court in Vienna: Kaiserhof or Reichshof?'

180 Duindam, Vienna and Versailles, 139-143.

181 Luc Duerloo, 'Pietas Albertina. Dynastieke vroomheid en herbouw van het vorstelijk gezag', Bijdragen en Mededelingen betreffende de Geschiedenis der Nederlanden 112 (1997) 1-18; Ragetli, 'Duchess between Prince and People'.

182 Marc Bloch, Les Rois Thaumaturges (Paris, 1924); Stephen Brogan, The Royal Touch in Early Modern England. Politics, Medicine and Sin (London, 2015).

183 Duindam, Vienna and Versailles, 139; Philippe Amiguet, ed., Lettres de Louis XV à son petitfils l'infant Ferdinand de Parme (Paris, 1938) 135-136. 
following his Rheims sacre in $1775 .{ }^{184}$ Monarchical practice, in Europe and elsewhere, was tied closely to magical-religious-moral beliefs. Without a doubt, the Reformation fundamentally changed views on sacraments and the divine; yet its direct impact on the perception of royalty should not be overrated. Only from the later seventeenth century onwards did, very gradually and mostly in higher social echelons, a secularized view of royalty gain sway.

In Europe the great ceremonial occasions attracted many part-time courtiers, who attended court mostly during the festive and ceremonial winter season, a time of leisure for soldiers because warfare was limited usually to the growing season. In the winter months, most European rulers would reside in their main urban residence, whereas from spring to autumn, they moved to hunting lodges and outdoor palaces - and sometimes to the battlefield. Ritual occasions were not only a moment for ceremonies and festivities; they usually coincided with the promotion of new honorary officers and knights in orders of chivalry. However, as in China, changes in the hierarchies of state servants were not primarily connected to celebrations. The season of rituals, concentrated in winter, from Christmas to Carnival and Lent and culminating in Holy Week, also formed the ideal opportunity for peripheral elites to meet at the centre. They might want to obtain luxury items, consider marriage candidates for their offspring, contract alliances, seek support for their litigations among central magistrates, or blacken their local adversaries. For the elites, the ritual calendar was necessarily also a social and a political calendar. When in the course of the eighteenth century the religious dimension of ritual, traditionally connected to interaction with a wider public, diminished, it did not leave a vacuum. Urban elites were increasingly integrated into the more secular festive cycles of court life, and several rulers, notably Joseph II of Austria, actively cultivated the connections with non-elite groups during their urban excursions and incognito travel. A popular image pictures Joseph II ploughing in Bohemia - at the same time, the French Dauphin, later Louis XVI, was also depicted ploughing. Did they mimic the Chinese emperor's 'ploughing the first furrow' at the Altar of Agriculture, a rite made famous by the Jesuits and commented favourably on by Montesquieu, who read it as an inducement for farmers?

The three elements of repetition, set rules, and physical enactment underlined above are relevant only in the context of physical presence and interaction. In the course of the centuries discussed here, the broadcasting of

184 See the study by Anne Byrne, looking at Louis XVI and ceremony, to be published by Oxford University Press, Marvellous Royalty: Kingship and Ceremony in France, 1774-1775. I thank the author for sharing her typescript with me. 
royalty increasingly proceeded through other media and reached audiences more distant in place and time-arguably it lost the immediacy of the ritual experience in the process. Monuments, insignia, coins, and inscriptions had long since been standard aspects of many court cultures. ${ }^{185}$ Stelae erected by magistrates can be found throughout Chinese history. Print was common in Song China, though it became more widespread in Ming and Qing China. Placards with guidelines for the populace became an important form of communication in Song China. ${ }^{186}$ The Ming founder initiated a policy of magistrates' 'village lectures' advising the locals about correct moral attitudes; the Qing emperors continued and expanded these practices. Emperors were present through the moral exhortations of their agents, although we should keep in mind the low numbers of magistrates.

West and South Asian courts employed all traditional means to show their splendour and power, but rulers could not uninhibitedly reproduce their images. Illustrated manuscripts were common across the region. In addition, the Mughals, Jahangir in particular, excelled in creating a rich, eclectic school of painting proclaiming their status as great and just rulers. Print, not much employed in the Islamicate world, was eagerly embraced in Europe. Habsburg emperor Maximilian printed lavishly illustrated books in addition to his use of all other media available to broadcast his views of kingship. ${ }^{187}$ Descriptions of court festivals, often depicting ideals rather than recording events, were published at many courts from the early sixteenth century onwards. ${ }^{188}$ From the later seventeenth century, the growth of the periodical press and the reading public multiplied and diversified these tendencies. At the same time, painting and statues spread the image of the ruler, more often than not in heroic postures. In the course of the later seventeenth and eighteenth centuries, the loose 'court culture' centred on a radiant court orbited by elites close and distant became more institutionalized: academies brought together artists, writers,

\footnotetext{
185 Flinterman, 'The Cult of Qalāwūn'.

186 Patricia Ebrey, 'Informing the Public by Posting Notices in Song China', paper in the conference: Political Communication in the Medieval World, 8oo-16oo, Rome, 27-29 May 2015 .

187 Larry Silver, Marketing Maximilian: The Visual Ideology of a Holy Roman Emperor (Princeton, 2008); Eva Michel and Maria Luise Sternath, eds., Kaiser Maximilian I. und die Kunst der Dürerzeit (Vienna, 2012).

188 See a concise discussion by Helen Watanabe-O'Kelly, “True and Historical Descriptions"? European Festivals and the Printed Record', in: Jeroen Duindam and Sabine Dabringhaus, eds., The Dynastic Centre and the Provinces: Agents and Interactions (Leiden and Boston, 2014) 150-159.
} 
and scholars, conferring a badge of honour on them that underlined the role of the court as the arbiter of rank. Napoleon's pragmatic view of human nature and his keen eye for effective historical examples convinced him to merge these forms into a multimedia representation of power. At the same time, he restored and expanded the monarchical 'economy of honour', attaching elites to his court and restructuring social hierarchies through his intervention. Finally, during the long Indian summer of European monarchy, cinema and photography provided a view of royalty that, again, gave spectators a semblance of proximity. ${ }^{189}$

Neither the rituals of royalty nor the explosion and diversification of media necessarily convinced the populace. As far as our sources can help us ascertain popular attitudes, they suggest that princely 'propaganda' was never taken at face value. Royalty might be seen favourably in principle, much as modernday citizens by and large accept democracy. Yet all rulers risked overstepping boundaries and thereby annoying or even infuriating their peoples. Bad rulers were as much present in popular culture as the ideal princes depicted in court paintings. It is very unlikely that subjects were ever persuaded to uncritically absorb the images of rulership created at the centre. Habsburg emperor Leopold I was appreciated by his distant subjects in Germany as a mild and somewhat hesitant figure, standing between the empire and the threats of the French and the Turks-yet nobody took seriously the heroic posture he adopted in court spectacle. ${ }^{190}$

In depicting a harmonious tableau of elite hierarchies, rituals made manifest the rank and status of the participants. Paradoxically, therefore, this show of harmony could give rise to contestations, mostly during the preparation of rituals, but sometimes during these solemn performances themselves. In diplomatic ritual, among participants who did not recognize a single arbiter or leading authority, conflict was endemic everywhere. Numerous diplomats of sovereign polities were in attendance daily at royal courts in Europe. Their presence compromised internal hierarchies in the domestic setting of court life, created many conflicts, and hence enforced a measure of codification of ceremonial conventions from the later seventeenth century onwards. However, the near-sovereign status of great nobles at many European courts, and the permanent altercations among these grandees, also contributed to the high

189 David Cannadine, 'The Context, Performance and Meaning of Ritual: The British Monarchy and the 'Invention of Tradition,' c. 1820-1977', in: Eric Hobsbawm and Terence Ranger, eds. The Invention of Tradition (Cambridge, 1983) 101-164.

190 Jutta Schumann, Die andere Sonne:Kaiserbild und Medienstrategien im Zeitalter Leopolds I. (Berlin, 2003). 
incidence of ceremonial strife. European ceremonial records, on the one hand, express unshakable order and fixed hierarchy; on the other hand, they detail endless minor and major squabbles about rank and position. In other parts of Eurasia, descriptions of ambassadors' audiences and entries also often show contestation, muted or open. However, local elites do not seem to have been as openly contentious as their European compeers, although they must have competed in other respects. This difference may be exaggerated because of the asymmetrical availability and nature of sources, a theme that needs further research.

As in the case of distribution of honours, the question of agency arises here. Did rulers actively use the physical language of rank and position to enhance their position and reduce others, or to play off one leading servant against another? There is ample evidence for the manipulation in the case of ambassadors and tributaries, who were belittled, infuriated, and appeased through situational ceremonial details. Did rulers and their advisors extend this policy to manipulate their own grandees and servants?

\subsection{The Court as Arena: Power Groups and the Prince}

Princes stood at the heart of the machinery of distribution, ritual, and decisionmaking. These processes converged at the dynastic centre in the hands of the prince. The whole make-up of dynastic power suggested that the ruler held control in person, and this also seems to be a common assumption among students of history. The statement by Finer cited in the opening of this essay, that 'decision-making rests with one individual', was true in theory, although advisors across Eurasia pointed out that good rulers should always carefully consider their councillors' advice. Yet how did decision-making work in practice? Any historian can point to weaklings on the throne who allowed others to dominate them. These cases, however, have not led us to question the assumption that most figures on the throne reigned and ruled. I suggest we should never take for granted that princes who held supreme authority in name also wielded power in practice: this assumption should be tested in every single case.

The presentation of rulership in monuments, rituals, and proclamations underlined the power of the ruler, the loyal support of his advisors and servants, and the unwavering obedience of his subjects. The mere questioning of this stylized representation of harmony, hierarchy, and order was tantamount to treason. A similar remark can be made about decision-making. At court, councillors might disagree behind the closed doors of the council chamber, but they were expected never to voice their criticism elsewhere. No dissonant views or opinions were to be pronounced in public. Francis Bacon, in his Essays, argued that the success of empire lay in the secrecy of the council. Contrasting 
opinions could be expressed with deference but freely at the council table, as long as decisions were broadcast unequivocally as the ruler's 'resolution and direction.' ${ }^{191}$ In the Analects, Confucius stated: 'he who does not occupy the office does not discuss its policy' - one among a number of oft-cited passages outlining the high moral profile of literati. ${ }^{192}$ Chinese imperial tradition did explicitly make room for certain officeholders to state their doubts: censors and high magistrates were allowed to remonstrate, deferentially voicing their moral concerns to the emperor in person. Princely mirrors from Europe to West and South Asia praised the honest advisor, who risked his life by telling his sovereign harsh truths, contradicting the golden-tongued phrases of his wily colleagues. Yet notwithstanding these songs of praise about honest advisors, overall the expectation was that criticism should not be voiced to a wider public. ${ }^{193}$

Neither was the formation of interest groups accepted: organizing opposition, too, was tantamount to fomenting strife, and approached laesa maiestas. Hence 'faction', a term often used to indicate competing groups at court, was mostly used as an accusation against rivals. Presenting oneself as member of a 'faction' was a highly unlikely course of action. The powerful tendency of Chinese literati to frame their activities in the language of exemplary morality forbade them from openly forming alliances and enmities. Confucius had stated: 'I have heard that the gentleman does not show partiality.' 194 Hence the followers of factions were to be found only among 'petty men'. In Europe it is quite clear that numerous groups and individuals contended for power around the court. They, too, shrouded their ambitions in deferential language; yet well-informed contemporaries were aware of animosities and intrigues. Sources complicate matters somewhat: court chronicles present an ideal of unruffled order, whereas outside observers focus on rivalry at court. In Europe the presence of numerous letters and diaries of courtiers helps to bridge the gap between idealized accounts and critical outside observations. Fewer materials of this nature are available for the Ottoman, Safavid, and Mughal courts, where the clash between court chronicles and outsiders' reports is more difficult to resolve. ${ }^{195}$

191 Francis Bacon, The Essays, John Pitcher, ed. (London, 1985) 'Of Counsel', Essays, 121.

192 Confucius, Analects, trans. William Edward Soothill (Edinburgh, 1910; repr. London, 1995) vol. v, book VIII, chapter XIV; see also vol. v, book viI, chapter XXX.

193 See chapter 5 in this volume, Maaike van Berkel, 'The People of the Pen', on the self-perceptions and moral views of leading officials.

194 Benjamin Elman, 'Imperial Politics and Confucian Societies', quote at 395.

195 See similar discrepancies between court chronicles and reports by the agent of the Dutch East India Company, used effectively by Bes, 'Imperial Servants on Local Thrones'. 
Competition at court tended to remain opaque until it flared out in the open. Where they are available, records of decision-making may register differing opinions of advisors, but they rarely provide details about the process between the expression of opinions and the recording of the final decisions. Once competition at court escalated into open conflict, groups and individuals involved can be defined more easily. Several times during the late Ming magistrates collectively protested against the infringement of time-honoured ritual precepts by the emperor, by crying, tearing their clothes and pulling out their hair in front of the Meridian palace gate. ${ }^{196}$ Factions in China tended to become manifest only in cases of conspicuous machinations of eunuchs and concubines, the bêtes noires of the literati. However, we must assume that power groupings were present on a daily basis behind the veil of deference and moral propriety. ${ }^{197}$ Interestingly, in his discussion of Ming decline, the Kangxi emperor blamed literati factions rather than eunuch power. ${ }^{198}$ In the Ottoman empire Janissaries forcefully intervened in nominations and decisions with some regularity and could be a decisive factor in succession strife. During moments of crisis, sultans incidentally consulted the assembled elites on their policies, making explicit which offices and groups were seen as the leading stakeholders of dynastic power. ${ }^{199}$ During Mughal, Safavid, and Ottoman succession struggles the competing candidates and their supporters necessarily stepped out in the open. In Europe, estates assemblies and urban corporations frequently quarrelled with rulers, most stridently in the century following the Reformation.

Somewhere between these outspoken clashes and the more common stress on order, obedience, and consensus, the everyday political trafficking at court took place. Who were the main players? Dynastic centres, sedentary or moving, were meeting places. Tributaries, leading office holders and grandees, petitioners and lobbyists moved to the centre to satisfy the demands of the ruler and to

196 John W. Dardess, 'Protesting to the Death: The Fuque in Ming Political History', Ming Studies 47 (2003) 86-125; Li Jia, 'Conflicts Between Monarch and Ministers', Chinese Studies in History 44, no. 3 (2011) 72-89; Fisher, The Chosen One. Succession and Adoption in the Court of Ming Shizong.

197 See the paper by Bossler cited in note 139, and Balazs, Political Theory and Administrative Reality.

198 Spence, Emperor of China, 87, on 45-46 Kangxi underlines that he never involved eunuchs in government; on faction see Elman, 'Imperial Politics and Confucian Societies in Late Imperial China', at 395, 402-403; on eunuch power McMahon, 'The Potent Eunuch', and Kutcher, 'Unspoken Collusions'.

199 See the 'consultation', or mesveret, by the young Murad Iv, reported in Bekar, 'The Rise of the Köprülü Family'. 
accomplish their ambitions. Peripheral elites converging at the centre used the occasion to revive old friendships, remind clients and followers of their duties, and in veiled terms ask patrons for support. They all tried to define the key players in the machinery of power and distribution. The process can be retraced in primary sources to some extent. Ambassadors' reports usually include a cast of characters, describing the main officials and grandees around the throne, noting their formal functions, their friendships and rivalries, and their credit with the prince or other key figures in the dynasty. These eager observers tried to obtain such information through locals on their payroll. Like travellers, diplomats at times used the printed or manuscript stories compiled by colleagues and predecessors to fill in missing details. While these overviews are frequently unreliable, they suggest which criteria contemporaries considered relevant for positions of power: leading administrative, military, and domestic office; personality and abilities; connections and friendships; and, finally, proximity to the prince always ranked high. Pedigree, wealth, and learning were often added to the picture.

These multiple attempts to outline a hierarchy of power at court suggest that there were always several overlapping hierarchies, based on different principles. Groups eligible for succession by definition held high rank—yet this very position made it unlikely for them to act as close confidants. Numerous African examples underline the tension between rulers and their brothers and sons in patrilineal contexts: these dangerous male relatives were often sent away, or held in some form of captivity. ${ }^{200}$ Affines, related to royalty through marriage but not entitled to succeed, were much preferred as allies and advisors. Conversely, in matrilineal contexts, tensions existed with potential successors through the female line, and sons and brothers turned into safe allies. ${ }^{201}$ Potential successors were unlikely to turn into trusted confidants. Phrased in more general terms: high rank did not easily coincide with daily proximity and friendship. Once more elaborate forms of government and decision-making emerged another category came to the fore: membership of the leading councils where decisions were deliberated.

The figure below shows three criteria of status pictured in three hierarchies: a pyramid of rank, an organization chart of decision-making, and concentric circles indicating proximity to the ruler.

All courts knew a formal ranking: moving from the ruler and his kin at the top, via princes eligible for succession, to grandees or prime dignitaries. We have seen that rank, visually demonstrated during the great ceremonies

200 See numerous examples in Duindam, Dynasties.

201 Tardits, Princes \& Serviteurs, 15, 17, 29-31, 114-117. 


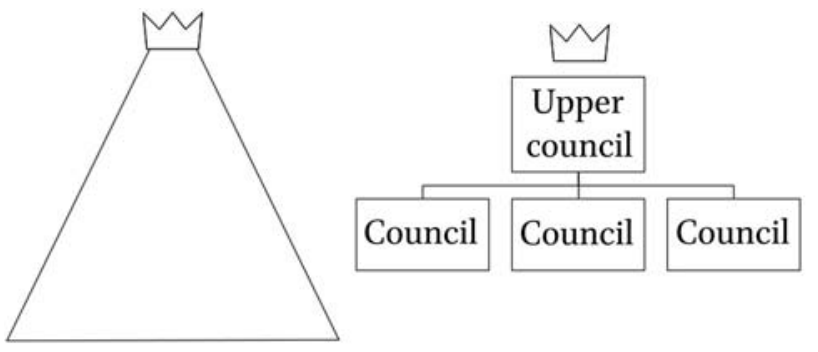

Rank

\section{Decision-making}

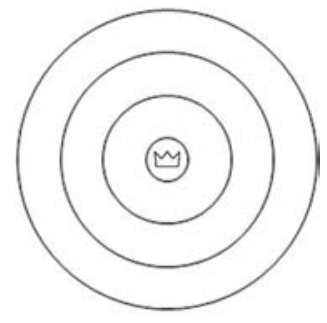

Access

FIGURE 2.1 Three contending and overlapping status hierarchies

of the realm, took very different shapes in the three macroregions of Eurasia. Figures in the top layers of the pyramid were not invariably the leading cast in the formal process of decision-making. The organization chart of decisionmaking usually included an upper council where key policy decisions would be discussed. This could be done in the company of the prince; alternatively, the results of the deliberations could be communicated to the prince in writing, or in person by the chief minister. These variants occurred in most polities over time. Under the supreme council a number of lesser councils would deal with more specialized matters, usually without the prince. Finally, at all courts a series of concentric circles can be drawn around the ruler, highlighting an inner ring of servants and confidants who were most often in his company. High rank or a major role in decision-making did not guarantee access: on the contrary, lesser-ranking servants were often the preferred category for intimate service. Women, present in the pyramid of rank but not usually prominent in the organization chart of decision-making, were invariably important in this inner circle.

No single group could dominate in all three domains; sharp status dissonances caused conflict among these hierarchies. Supreme birth rank and eligibility for succession created potential for conflict with the incumbent ruler and called into question an individual's suitability for top positions in central government. Dynastic siblings across the globe were often under some form of surveillance; their relationship with the paramount ruler was rarely carefree. The situation of this group worldwide justifies to some extent the metaphor of the gilded cage, although it cannot be extended to include the nobility at large. ${ }^{202}$ Tension among the hierarchies was not limited to the dynasty. Like

202 On Amba Geshen, the 'royal mountain' of the Solomonids in Ethiopia, where members of the dynasty were confined, see Duindam, Dynasties, 152, 210, 292. 
dynastic siblings in many regions, daimyo in Japan and high nobles in several European polities, did not as a rule hold executive powers in the highest councils. High-ranking grandees begrudged the rise to power of lesser-ranking specialists in the ruler's councils. Finally, neither leading administrators nor grandees were able to fully control the daily and nocturnal environment of the prince: they resented inner-court female, eunuch, or male confidants, who could undermine their position by influencing the sovereign. Prominent Chinese literati expressed their abhorrence of eunuchs and concubines. Upper daimyo were at times irritated by the powers of chamberlains and advisors from the lowest echelons of the warrior class. ${ }^{203}$ Ottoman grand viziers needed to reckon with the eunuchs as well as with the most important harem women.

The inner-outer divide and the practice of withholding executive political power from the highest-ranking elites, especially those eligible for succession, can be found at many courts. This made the emergence of a single, uniform power group unlikely. While inner-outer tension can be documented for many courts throughout history, it was less consistent in Europe. European courtiers frequently complained about the power of mistresses and at times about lesser chamber servants. Perhaps the mistress, with a greater potential for domination than the legitimate dynastic spouse, comes closest to the form of innercourt power found at polygynous courts. Nevertheless, in Europe advisors were not rigidly barred from the ruler's apartments. ${ }^{204}$ Noble honorary servants in the household could combine domestic service with a role as advisor or chair of the council. In some polities they were prominently present in all hierarchies: the high steward in Habsburg Vienna, invariably a high nobleman, also chaired the privy council in most of the seventeenth and part of the eighteenth century. Conversely, from the start of Louis XIv's personal rule to the ascension of Louis XVI, there were protracted phases of greater social and functional separation between the council and leading office in the household.

The relevant question here is whether structural rifts in the make-up of courts determined conflict. Political contestation took various shapes depending on what was at stake. Status groups would protect their collective interests if these were under attack. Incidentally, foreign threats or religious upheavals changed the political landscape, creating unexpected enmities and alliances on the basis of conviction rather than rank or pragmatism. More often, however, those closest in rank and status competed for the same benefits. Mag-

\footnotetext{
203 On the rise of the chamberlain under the Tokugawa shoguns see Totman, Politics in the Tokugawa Bakufu, 99-103; 214-217; Bodart-Bailey, The Dog Shogun, 103-127.

204 See an assessment of high courtiers, ministers, and access in the French context, Duindam, Vienna and Versailles, 101, 246.
} 
istrates could hope for the same nominations to high office; they might also compete in recommending their protégés for office. Everywhere at least two aspects of 'politics' can be distinguished. Firstly, the 'macropolitical' domain of major policy decisions: war, peace, alliances, major government reforms, or religious choices. These choices would have consequences for the entire realm for decades to come. Secondly, the 'micropolitical' domain of nominations to office and grants of benefits in the hands of the ruler. At the highest level, the two domains overlapped: by appointing a leading grand secretary, grand vizier, or first minister the ruler set the course for policy decisions. In the absence of marked crises, competition over the distribution of benefits continued on a daily basis: this was the basso continuo of court politics.

The pervasiveness of 'micropolitics' at court inevitably turned peers into rivals: it was imperative for the main contestants to seek support in the other hierarchies against the proximate rivals in their own hierarchy. The chief white eunuch of the Topkapi palace school noticed with dismay the rise to power of the chief black eunuch in the harem and sought support among outercourt dignitaries. Sultan-Mothers and favourites in the harem were often at loggerheads - and the single instance where a grandmother as well as a mother was present ended in bloodshed. The household military of the outer court were consistently divided, with the sipahi cavalry regiments acting as the foremost rivals of the Janissaries. Prominent viziers hoping for the final promotion to the grand vizierate, obviously, would seek support in the inner court rather than among their competitors for this highest honour. At the same time, competing pashas and viziers would rely on their own households, bringing together kin, loyal servants, and clients. Typically, the asymmetrical loyalties of patronage tied together households in a single alliance more easily, and lastingly, if a clear priority of rank was acknowledged among the allies. The alliance of equals more often was fleeting and contingent upon special circumstances.

The same statement can be elaborated for French upper echelons. High nobles relied on networks of clients in the provinces or in the institutions they supervised, and sought support among ministers in the council-who, likewise, saw their direct colleagues as prime contenders. Princes and dukes in high domestic office were always competing, and the tension between the Louvois-Colbert ministerial clans lasted through most of Louis XIV's reign. There are sufficient grounds to extend this view to Mughal and Safavid practice, where top mansabdars with their households or the increasingly vociferous former Qizilbash devotees also competed for status and power. The absence of detailed studies of patronage or recommendation and the strong cultural bias against faction in the Chinese case raises the question whether this model is valid for the Ming and Qing courts. Nevertheless, it seems safe to conclude 
that socially and functionally diverse hierarchical alignments based on kinship and personal loyalties formed the most persistent and lasting power groups at court.

Who actually held control? This is a question mal posée. All attempts to capture conflict at court in one single formula necessarily fail because of the variability of political constellations and the diversity of persons on the throne. Talented kings had at their disposal numerous instruments to create order and submission at their courts. The histories of their predecessors, often a key part of their training, formed a repository of useful ruses as well as moral exhortations. Most practical guides to governing written by rulers expound on the subject of nominations, underlining first and foremost that the ruler should carefully guard this right. Han Feizi, criticising Confucius's moral stance as unrealistic, presents the emperor as a tiger, with punishments and rewards as his claws and teeth; leaving these to his ministers, he will be controlled by them. ${ }^{205}$ The distribution of favours made it easy to acquire a following for the emperor as well as for his leading servants: 'Take warning when there are many men gathered at the gates of the high ministers!', Han Feizi warned the emperor. ${ }^{206}$ This perspicacious caveat summarizes well Louis XIV's attitude vis-à-vis his most important servants at court and in the council. The Sun King time and again emphasized the importance of the distribution of honours in his memoirs and underscored the risks of relying on a sole principal advisor. ${ }^{207}$

Depictions of royal power thus rightly point to this huge potential in the hands of the ruler. The presence of many contenders around a single figure distributing boons made it easy to change group hierarchies and manipulate competitors. Rulers steadfastly and effectively concentrating on the adage to 'divide and rule' could expect to successfully maintain their position at least while they were strong and healthy. Acting as the arbiter between ambitious competitors, they could reduce those who had the best chances to turn into their rivals. All rulers of some calibre knew that they courted disaster when they allowed nominations to slip from their hands.

The balancing game could be played in many ways. Did rulers actively use the choreography of ritual to undermine overmighty subjects? Rituals of rulership were hardly a stress-free opportunity for manipulation. In the Chinese case, where ritual propriety towered above all other concerns, this observa-

\footnotetext{
205 Han Fei Tzu: Basic Writings, Burton Watson, ed. (New York, 1964) 30-34.

206 Han Fei Tzu: Basic Writings, 39.

207 Louis XIV, Mémoires, Dreyss, ed., II, 2O-21; 42-43; 238-239; 341-342.
} 
tion needs little further comment. Elsewhere, too, ceremonies were first and foremost a collective show of power and magnificence: open competition disturbed this performance, to no one's benefit. Only in the European context do we hear much about competition during ceremonies, and this mostly reflected negatively on the prince: how could he rule effectively if, even in this special and dignified setting, he could not secure proper proceedings? Open rivalry during ceremony strikes me as a sign of princely weakness rather than strength. The fact that it did occur during diplomatic meetings underlines the status of diplomats as the personal representatives of their ruler: by accepting forms of meeting and greeting that diminished their status, they would acknowledge, before all present, the inferiority of their sovereign —and this was intolerable. The most frequently cited examples of manipulation by Louis XIV are based on Saint-Simon's descriptions of morning and evening meetings at the king's bedside. Yet, here too, almost everything was carefully graded according to the rank of those present. Only one minor privilege, the presentation of the chandelier, was left to the king's discretion. Competition during these domestic traditions of 'open' French kingship, gradually becoming formalized under Henry III, could be downright humiliating. Louis XIV once had to wait glumly until his two quarrelling dignitaries had decided who would have the right to present the overcoat. ${ }^{208}$ Surely there were better occasions for distribution, multiplication, and manipulation of honours.

Conceited, ambitious, and disrespectful grandees anywhere were easy prey for rulers, who punished them without resorting to the machinery of distribution of honours. Some rules of thumb must have been inculcated in the education of princes: never rely on one figure only, distribute graces evenly and with appreciation for loyalty as well as capability, beware of the strongest and most ambitious among your servants and prevent them from usurping your powers. Not all figures on the throne were able to play this game. Particularly in vulnerable phases of the lifecycle, the discomforts of the elevated royal position made it attractive for incumbents to rely on trusted intermediaries. Paradoxically, for them the most obvious escape route was the antithesis of the key principle of rulership: seeking shelter behind a single trusted favourite who would henceforth deal with the troublesome details of court life. Many kings understood that their confidence could be sought after for instrumental purposes; yet this did not make them impervious to friendship and confidence. Few kings consistently used the distribution of favours to their advantage, without ever losing

208 Philippe de Courcillon Dangeau, Journal du Marquis de Dangeau, Eud. Soulié and L. Dussieux, eds., 19 vols. (Paris, 1854-1860) II, 123, 25-3-1688. 
control. Enthusiastic manipulators, stimulating the competition between factions at their court, risked escalating the game to uncontrollable proportions, either in their lifetime or under their successors. In an attempt to achieve 'grand harmony' King Yongjo of Choson Korea tried to pacify the factional conflicts exacerbated by preceding kings. This effort played a part in the king's increasingly hopeless relationship with his heir-apparent, who in the end was forced to commit suicide. ${ }^{209}$ Playing this game and escaping unscathed demanded great discernment and force of character-a combination found more often among outsiders rising to power through their own actions than among princes formed by court education. This combination of strengths, moreover, could only very rarely be maintained during a lifetime on the throne.

The wars and regencies of the middle seventeenth century, of awesome magnitude in China and more modest but still disconcerting in France, stood at the beginning of the long and successful reigns of Kangxi and Louis XIV, two rulers rightly seen as builders. Both started out as infant kings under the control of regents and (grand)mothers; both found their way to effective rule-and both saw their hold on power weaken in their later years. Louis XIV in his memoirs articulated a policy to grant the great nobles all honours they deserved, without, however, giving them the right to sit in his council. ${ }^{210}$ In addition he argued that relying on more ministers at the same time, rather than on a single, towering figure, would give him leeway, because 'the jealousy of one would put a brake on the ambition of the other. ${ }^{211}$ After the deaths of Louis XIV's leading ministers Colbert and Louvois, the period of easy successes had passed. A difficult European political constellation, less successful and changing ministries, the growing clout of the king's morganatic spouse, Madame de Maintenon, and a series of deaths in the royal family left the king increasingly dependent and uncertain. Kangxi started his personal rule at an earlier age than did the Sun King. In his coup against the Manchu regency, Kangxi relied on competitors of the regents in Manchu circles as well as on Han Chinese advisors. The emperor,

209 JaHyun Kim Haboush, The Confucian Kingship in Korea. Yŏngjo and the Politics of Sagacity (New York, 1988); Haboush, ed., The Memoirs of Lady Hyegyong: The Autobiographical Writings of a Crown Princess of Eighteenth-Century Korea (New York, 1996); Peter H. Lee, Sourcebook of Korean Civilization: Volume Two: From the Seventeenth Century to the Modern Period (New York, 2013) 39-43.

210 Louis XIV, Mémoires, Cornette, ed., 71. This statement has often been interpreted wrongly as an innovation: it actually restored a situation that was common in many other monarchies.

211 J.L.M. de Gain-Montagnac, ed., Mémoires de Louis XIV écrits par lui-même (Paris, 1806) I-II, I, 18 . 
who persisted longer on the throne than did his French contemporary, was shattered by the unrelenting conflicts with his heir-apparent, and ended his reign disheartened. Addressing his main officials in 1717 when he felt death approaching, Kangxi himself stated that:

After my serious illness in the forty-seventh year of my reign, my spirits had been too much wounded, and gradually I failed to regain my former state. Moreover, everyday there was my work, all requiring decisions; frequently I felt that my vitality was slipping away and my internal energy diminishing. ${ }^{212}$

Elsewhere in the same edict the emperor asked himself: 'how can I attain the day when I will have no more burdens?' Kangxi shed 'tears of bitterness' while he shared these thoughts with his officials. Typically, the edict was published posthumously without a trace of the emperor's despondency. Older rulers everywhere expressed their uneasiness with the increasingly heavy burden of their daily tasks as well as with the impatience of their successors. The Qianlong emperor, who ruled as long as his grandfather, seems to have eluded the despondency of old age-yet a notorious favourite dominated the last decades of his reign. It is difficult to find examples of long-living rulers who remained in control throughout their lives.

These lifecycle events and attitudes, expressed with particular acuity in Kangxi's own words, do not contradict the successes of these rulers. They do show, however, that even strong figures, in all stages of their career, depended on the advice and support of others. The balance of dependence changed over time in these relationships. Only in the decades of their greatest physical and intellectual vigour can they be seen as the dominant force; and even in these years they more often than not followed the advice of their councillors. Reconstructing this changing chemistry of advice, moral support, competition, and mutual manipulation is possible only in exceptional cases. At the heart of dynastic rule, agency is difficult to capture in detail—there is no 'black box' to be traced and interpreted here.

Moving from the lives of individual rulers and their servants to longer-term developments, it is easy to recognise patterns. A first impulse of many kings was to seek advice and intimate support beyond the circle of leading elites. Outsiders of all kinds, people with little or no previous connection to the power networks orbiting the court, were preferred candidates. Outsiders could

212 Spence, Emperor of China, quotes on 148, 150; the edict as published later on 169-175. 
be found in less prestigious social groups. We have seen that shoguns were keen to control the daimyo closest to them in rank-particularly those who had not supported them during the decisive battle of Sekigahara (16oo) - and hence looked for support in the lower echelons of the warrior class. Sometimes rulers went further and created new elites. The introduction of the civil service examinations in China can be understood as an attempt by the dynasty to reduce its reliance on a limited number of established families who still dominated in Tang China, but did not resurface under the Song. The introduction of devshirme and its gradual extension in the course of the fifteenth century marginalized previously powerful Ghazi frontier-warrior families and created a new ruling class of 'slaves of the sultan'. The strong ties of religious disciples to their spiritual guide and master gave force and cohesion to the first phase of Safavid rule under Shah Ismail and contributed to Akbar's comprehensive overhaul of the Mughal power structure.

Celibacy or the inability to procreate was an additional safeguard against advisors turning into overmighty subjects, which helps to explain the important role of clerics in European government and eunuchs in many other places. Clerics, obviously, also had the major advantage of literacy and learning; and among males, only eunuchs could guard the harem without compromising the patrilineal dynasty. Exiles or foreigners frequently served as advisors at courtin Europe this tendency was strengthened by the relocation of kings to distant regions following the vagaries of dynastic demography and succession: moving elsewhere, they brought companions from their homelands. On a different scale, a parallel process occurred when conquest clans captured huge empires and became dominant minorities there, most notably the Manchus in Qing China. The Qing emperors, moreover, ruled the peripheries of the empire with local elites, while they adopted Han Chinese customs for the core areas, albeit infused with a strong Manchu presence. These examples all underscore the potential powers of rulers, who could indeed act as balancers, and at times as social engineers in the style of Napoleon, planning the formation of elites and ensuring their loyalty with a mixture of rewards and punishments.

At least two qualifications need to be added, related to the degree of planning and to longer-term consequences. Most plans took shape in a series of ad hoc measures, gradually coalescing into a fixed policy, usually encompassing more than one reign, and sometimes more than one dynasty. A capacity to learn from previous examples was present in the dynastic memory, with its reasoned catalogue of vices and virtues of earlier rulers. These surely helped to establish basic policies vis-à-vis dynastic rivals and elites. It is difficult, however, to accept with confidence long-term 'masterplans' of rulers. Only during long and violent phases of changeover, when routines had almost disappeared 
and a comprehensive reordering of the realm was inevitable, do we find clear signs of conscious social engineering. These crises did occur with some frequency in dynastic history. A second qualification pertains to the long-term consequences. In the centuries following dynastic builders, their successors failed to maintain their grip on power, and measures of the builder-founders usually had unforeseen consequences. Louis XIV's successful reform of the French court and his attempt to unite loyal elites under his rule by granting them all a juste mesure of power and prestige in the following century consolidated the semi-monopoly of French court nobles on high office. ${ }^{213}$ Within forty years after the death of Shah 'Abbas I, the elites he had effectively reined in acted unashamedly as kingmakers and dominated the rule of Suleiman I. This shah was appointed thanks to the intervention of a court eunuch who vehemently opposed the council's choice of a younger prince, arguing that they were only aiming for a long period of elite rule. The eunuch's principled intervention did not prevent Suleiman's reign from turning into a permanent struggle between various elites manipulating their ruler. Engelbert Kaempfer reported the ongoing competition between the 'day council' and the 'night council' at the court of Safavid Shah Suleiman I (1647-1666-1694), with the women and eunuchs in the inner court undoing their rivals' daytime decisions. ${ }^{214}$ The tug of war between inner and outer court, and between different groupings among the elites in the outer court, dominated Suleiman's rule. The shah, entertained, intoxicated, and manipulated, was the bone of contention, the object rather than the master of the game. The same can be said about several Ottoman sultans, who were put in power by their leading elites rather than through their own force-although the strength of the dynastic legacy among the population may have contributed to the kingmakers' reticence. The tendency of dependent service elites to become vested semi-hereditary elites, within two or three generations, is as striking as the innovations introduced by empire builders. The Chinese civil service examination, reproducing the gentry literati elite without allowing heredity in office, was a remarkably lasting compromise that provided legitimacy to emperor and magistrates alike. The loyalty of the Manchu banners appears to have lasted relatively long - this may in part be explained by the minority status of this ruling elite in Han China.

213 Horowski, Belagerung des Thrones.

214 See a striking example of kingmakers choosing a boy-shah and a eunuch stepping in to defend the rights of an older son, Matthee, Persia in Crisis, 56-58; Engelbert Kaempfer am Hofe des persischen Grosskönigs, 37-38; Chardin, Voyages du chevalier Chardin, vol. 9, with the eunuch's speech printed on $435^{-437}$. 
An astute prince can rule by dividing his elites; yet he himself in old age, or his less talented successor, might be haunted by conflicts he could no longer control. Competition at court can be the result of princely manipulation, as well as the cause of princely impotence. Insecure kings could choose to leave most tasks to a favourite; others created new favourites to push aside those established in power by their predecessors. ${ }^{215}$ No established group or individual at court wished to see a perennial gale of mutual destruction through faction; most were willing and eager to establish order, preferably with a vested position for themselves. Looking at the endless repetition of power games at many different courts, I see alternating and recurring patterns, but never one singular, universally valid mechanism. It is necessary, moreover, to correct the assumption that the ruler himself was advantaged by the structure of the court, which multiplied his potential as well as his vulnerability. Manipulation demanded rare qualities and was likely to turn against the ruler or his successors at some point. Not without reason, Chinese tradition censured overactive rulers. But no tradition could define a universally ideal balance between engagement and non-action, which varied according to the circumstances. In all forms of dynastic power, whether rulers styled themselves as firstamong-equals or as unassailable autocrats, competing hierarchies surrounded the ruler. Most often these contending elites took care to respect the prerogatives and status of the ruler; yet as a rule they were able to tap the wealth and power accumulated at the centre. This fuelled the connections between central elites and their clients in the provinces and hence formed a key component of dynastic power. The 'iron law of oligarchy' uncovered by elite theorists, who in the later nineteenth and early twentieth century underlined the role of oligarchies in modern democracies, is equally relevant for all varieties of dynastic power, from the primus inter pares to the all-powerful autocrat. ${ }^{216}$ There is

215 Jeroen Duindam, 'Der Günstling global? Favourites and Faction at Early Modern Courts' (2015) https://mittelalter.hypotheses.org/6524; Börekci and Peksevgen, 'Court and Favorites'; Börekci, 'Factions and Favorites at the Court of Sultan Ahmed I and His Immediate Predecessors'; Baki Tezcan, The Second Ottoman Empire: Political and Social Transformation in the Early Modern World (Cambridge, 2010); Bekar, 'The Rise of the Köprülü Family'.

216 Robert Michels, Zur Soziologie des Parteiwesens in der modernen Demokratie: Untersuchungen über die oligarchischen Tendenzen des Gruppenlebens (Leipzig, 1911), 'Die Demokratie und das eherne Gesetz der Oligarchie', 362 . See also Gaetano Mosca, The Ruling Class (New York, 1939) and a lucid discussion by Putnam, Comparative Study. See also Ronald Syme, The Roman Revolution (Oxford, 1939) 7: 'In all ages, whatever the form and name of government, be it monarchy, republic, or democracy, an oligarchy lurks behind the façade; and Roman history, Republican or Imperial, is the history of the governing class'. 
ample reason to restore initiative and agency to all groups at court, including to the echelons of servants who well knew how to reach their goals while creating a lasting image of royal omnipotence.

\section{Conclusion: Courts, Legitimacy, and Change}

All courts considered here were organized primarily as households of male princes, with staffs catering for roughly equivalent tasks. Military and administrative services clustered around this domestic core. Court life followed a calendar alternating between everyday routines and great celebrations; numerous visitors joined the permanent staff during these special occasions. Notwithstanding the increasing differentiation and specialization of government services, the domestic core could not be disconnected from decision-making wherever the prince was sovereign.

Beyond this first rather crude overall equivalence, several major differences immediately spring to mind. Polygyny, whether or not combined with marriage, was common throughout the world, with the exception of Christian Europe, where monogamous marriage was the rule. The prevailing marriage practices shaped the arrangement of palace compounds and the rules for access to the ruler. The numerous women present in the harem, moreover, formed an important element in the circulations and connections between the dynasty and the realm, essential for several African kingdoms, but relevant for all Asian empires in one way or another. Polygyny ranked high among factors moulding the contours of dynastic alliances and the nature of the dynasty, but it could lead to very different constellations. Competition among brothers purged the dynasty of collaterals in every generation in West and South Asia; royalty here was a small group, comparable in numbers to European royal lineages. In polygynous East Asia, however, collaterals proliferated and served as a reservoir preventing extinction of the main line through adoption.

Polygyny led to secluded female inner quarters at court, often guarded by eunuchs. This reduced the facility of access, particularly if the male ruler resided in this inner female domain. The inner-outer divide was less rigid at European courts, where the same nobles could at times serve the ruler at his bedside and in the council—an accumulation of tasks unlikely in other parts of Eurasia. Princes could withdraw into their own quarters among a select group of favourites, but this was possible in Europe as well as in Asia, and nowhere did it become standard practice. The near-contemporaries Murad III, Rudolf II, and Wanli (the latter two in their later years) did this, and in the same 
years Henry III of France reformed his court to create a more secluded inner sphere. Conversely, Murad IV, the Bourbon kings, and the Qing emperors were far more outgoing. On the whole, the harem did lead to a greater seclusion. Did the presence of the prince in this isolated female-eunuch domain fundamentally change the contours of decision-making and conflict at court? Was this factor the key contrast between European and Asian 'palace polities'? It is not easy to substantiate or disprove this statement because of the immense variation in personalities and circumstances. The effort to count and rate the wisdom or stupidity of rulers and their advisors, and relate the outcomes to the absence or presence of the harem, cannot effectively be undertaken as an academic exercise. Wisdom and perseverance, narrow-minded ad hoc policies, and dramatic incompetence can be found in all polities in Eurasia. Rulers like Charles II of Spain or the Safavid Shah Suleiman were at the mercy of elites orbiting their courts; their near-contemporaries Louis XIV and Kangxi fared better. The attitudes and experiences of rulers, the shared contours of competing hierarchies, and the recurring characteristics of power groups at court cast doubt on the assumption that polygyny and monogamy created a qualitatively different structure of decision-making and princely power. Overlapping hierarchies of rank, decision-making, and access were present at all courts, and likewise the rivalry among equals can also be accepted as a general phenomenon.

European dynasties were tied together in a web of succession rights. Male lines predominated, but alliances between dynasties were formed through marriage exchange. Women represented their houses and the 'purity' of their bloodline entitled them to dynastic succession, particularly in the absence of male candidates with equally strong claims. Women ruled as sovereigns in Europe more often than elsewhere in Eurasia. ${ }^{217}$ Monogamous dynastic marriage, however, should not be equated with dynastic stability and the absence of violence. It heightened the chance of extinction as well as the incidence of physical or mental disabilities of incumbent kings caused by inbreeding. Monogamy and primogeniture relocated rather than prevented violence. Male primogeniture reduced internal succession strife, but extinction and the clash of pretenders based in other polities proved a familiar igniter of warfare in Europe. This is no firm ground for a straightforward contrast depicting European monarchies as developing in a more rational and peaceful way than their 'Eastern' rivals. It is possible, however, that kings triumphing in succession wars, more than in outright wars of conquest, were under the obligation to respect

217 Duindam, Dynasties, 87-108. 
corporate custom and privilege, particularly if local elites had supported their claims. In this sense, the dense dynastic web may have contributed to the persistence of hereditary and localized power groups in Europe.

Elite recruitment and the degree of hereditary power and autonomy held by elites mark another difference between the major polities of Eurasia. Disciples, slaves, scholars, and nobles presented their position and legitimacy in distinctly contrasting ways. They used different languages vis-à-vis their dynastic leaders, all imbued with loyalty and respect but nevertheless expressing profoundly dissimilar worldviews. The self-representations of these elites, however, seem to contrast more sharply than did their actual positions. ${ }^{218}$ They all, in various ways, depended on the court as a centre of redistribution. In the long run, they were all able to secure social reproduction as a group, granting the downfall of some and the rise of others. Mobility was often overstated in the Chinese case, with the cliché of commoners rising from rags to riches, or conversely, prominent magistrates falling from power and leaving their offspring in rags. European social climbers adopted family heraldry, genealogy, a castle, and a noble lifestyle as soon as their position allowed this. The downfall and extinction of many noble families was silently compensated by the entry of social climbers. Slaves could act as masters once they had monopolized the highest echelons of the Ottoman apparatus and rendered hereditary many of their privileges. In the course of the seventeenth and eighteenth centuries, the most successful among them, although never free from the risk of demotion, confiscation, and execution, formed a leading echelon. ${ }^{219}$ The religious fervour and adoration of Qizilbash disciples for their charismatic Safavid Shah were less easily transferred to next generations than the privileges and power they assembled during their lives. Elites in most European polities had a more explicitly autonomous position, which they defended vociferously. Yet European fiscal-military states, negotiating endlessly with their stakeholders, were increasingly dominant in society. Conversely, Chinese elites showed great deference and formally enjoyed less leeway in their interactions with the imperial magistracy and the dynasty. Yet the magistrates formed a minute proportion of the population, and from the seventeenth century onwards the state was

218 See, however, the consistency of self-representation among the people of the pen noted in Maaike van Berkel's chapter below.

219 On the gradual increase of heredity among Ottoman officeholders, see Dror Ze'evi and Ilkim Buke, 'Banishment, Confiscation, and the Instability of the Ottoman Elite Household', in: Dror Ze'evi and Ehud R. Toledano, eds., Society, Law, and Culture in the Middle East: 'Modernities' in the Making (Berlin, 2015) 16-30, particularly 20 figure 1.2. 
surely far more distant in China than in Europe. West and South Asian examples stand between these extremes. In each of these cases, the critical issue was whether the dynastic centre retained control of the instrument of distribution of honours. Overall, as Victor Lieberman points out in his comparative study, the centuries often grouped under the label 'early modern' seem to show the increasing presence of the dynastic centre in most Eurasian polities. ${ }^{220}$ However, this leaves open the difficult question of who, at the centre, controlled the machinery of patronage.

Another major variation can be found in the styles of rulership. Interaction with the populace went together with an active martial ideal of rulership in Europe and in West and South Asia. In East Asia, the ruler primarily served as the ritual sacrificer and moral exemplar, whose self-improvement and propriety were far more important than visibility or martial action. Within this broad contrast, endless nuances can be added, between different Chinese dynasties, between China and Japan, where the roles were divided between the emperor and the shogun, between various West and South Asian examples, between differing European court styles, and between endless numbers of individuals on the throne. East Asian views of rulership entailed the reduced personal visibility of the East Asian emperor in ritual and in redistribution, but these two functions nevertheless remained essential. In Japan, the shogun took over redistribution and left to the emperor the hidden ritual tasks. In China, where the ritual responsibilities of emperors were equally daunting and likewise mostly performed in relative isolation, incumbent emperors could maintain more power and freedom of action.

A final question needs more thought. Is there an element of change over time here? Did all courts move towards consolidation, differentiation, increasing distance between the domestic core and government, growing restrictions on the personal agency of the ruler, and a tendency towards greater distance from the population at large?

In European historiography these changes have traditionally been presented as a gradual move towards modernity. Late-medieval monarchies separated household and government, a process that continued throughout the early modern age. The growth and differentiation of administrative institutions went together with a gradual reduction of the mobility of royal households. The interactive and mobile courts of the late Middle Ages became sedentary, and kings lived in outdoor palaces that curtailed the ritual connections with their

220 Lieberman, Strange Parallels. 
realms. Mixed monarchies based on some power-sharing became 'absolute'. As the last stage of this process:

The household was swallowed by its own offspring, so to speak, it became simply one of a great many administrative departments whose responsibility happened to be looking after the monarch's person, his residences, his property, and the like. ${ }^{221}$

The metamorphosis was now complete, the court was subsumed under the state, and the whole constellation ready for the revolution and the rise of popular sovereignty. This view is comfortably linear and teleological-it is overstated rather than wrong and needs to be placed in the context of developments elsewhere.

Historical views of change in dynastic settings registered similar phenomena, yet connected these to decline rather than to a movement towards modernity. Such views, expressed with great force by Ibn Khaldun and reiterated in many forms throughout Chinese tradition, have a decidedly normative slant. Theirs is a story of inevitable decline, with strong founders whose palace-born successors lose robustness of character, discard moral restraints, start exploiting their populations, forfeit the loyalty of their adherents, and, finally, evoke the wrath of heaven and the rebellion of their peoples. Throughout Eurasia the domestic environment of rulers held a mixed reputation; it figured as the epitome of high culture and refinement, which at the same time was always perilously close to depravity and decadence. The voice of the honest advisor was rendered inaudible by the self-serving entreaties of more numerous sycophants. Rulers themselves were stereotyped as good or bad kings, as just rulers or bloody tyrants. Yet the ambition and intrigue of servants could undermine even the most sensible and docile ruler. Eunuchs, concubines, and meddling mothers were typecast as the agents and harbingers of decline. In China the literati elite viewed the inner court as morally and culturally deficient, rather than as a cultural model. 'Ulama' and priests censured the moral deficiencies of the court, but they connected these failings to its role as a centre of high culture: magnificence easily turned into extravagance, cultural sophistication into moral rot.

Cyclical views of dynastic power predicted change and made it acceptable, integrating rebellion into the overarching continuity of the mandate of heaven.

221 This restatement of a classic view can be found in Van Creveld, The Rise and Decline of the State, 130. 
TABLE 2.1 From personal valour to institutional consolidation: models, types or phases of rulership?

\section{Itinerant}

Personal activism

Martial-style rulership

Interactive

Heterodox

Charisma

Social mobility; unified new upper layer; 'asabiyya (group-feeling)

\section{Fixed}

\author{
Institutional consolidation \\ Moral exemplars, wu wei \\ Withdrawn \\ Conformist \\ Veralltäglichung \\ Social stasis; divided upper layer; \\ divide et impera
}

Princes and their advisors responded to this moral model. The Ottoman elite around 1600 wondered whether the changes in their political environment indicated a downturn as prophesied by Ibn Khaldun. ${ }^{222}$ The Qing, upon their rise to power, reduced the inflated court, purged the ranks of eunuchs, and restricted the role of the empress. When the Kangxi emperor froze the head tax at the 1711 level, he must have been considering his responsibilities towards people and heaven, quintessential for his reputation as a good ruler. ${ }^{223}$ These traditional cyclical views bring to mind the contrast mentioned at the opening of this essay between charisma and Veralltäglichung. Table 2.1 printed above brings together various characteristics of rulership in two opposed 'idealtypes'. These types suggest tendencies rather than actual examples; moreover, they may refer to regional differences as well as to development over time.

Typically, founding emperors from Chinggis Khan, Zhu Yuanzhang, and Timur to Napoleon match many characteristics in the first column; successors in a long-established line acquired more traits listed in the second column. Most founders, however, were keen to obtain the sanction of tradition and tended to move towards conformity once in power. East Asia fits better the second column, whereas Europe, as well as West and South Asia, shows a more mixed pattern. Central Asia, with its repeated waves of unification and

222 Cornell H. Fleischer, 'Royal Authority, Dynastic Cyclism, and "Ibn Khaldunism" in Sixteenth-century Ottoman Letters', Journal of Asian and African Studies 18 (1983) 198-220.

223 Jonathan Spence, 'The K'ang-hsi Reign', in: Willard J. Peterson, ed., The Cambridge History of China Volume 9, Part 1: The Ch'ing Empire to 1800 (Cambridge, 2002) 120-182 at 124, 178; Madeleine Zelin, The Magistrate's Tael. Rationalizing Fiscal Reform in Eighteenth-Century Ch'ing China (Berkeley, Los Angeles and Oxford, 1984) 12. 
conquest, appears as the area connected most strongly to the first column. In this respect, it matches the dynamic history of African segmentary states and Southeast Asian 'galactic polities', with sharp oscillations between partitioning and reunification.

This contrast can be connected to the question posed at the beginning of this book: why do elites comply? We have seen that popular attitudes are notoriously difficult to gauge. There is information about the self-perception of rulers and ruling elites, and about the idealized attributes of power they underlined in their attempt to acquire legitimacy. Grudgingly accepting for the moment the difficulty of reconstructing the reception of dynasty among the population, I recapitulate the intended audiences of dynastic legitimacy, the ingredients of the dynastic mandate, and the forms and occasions of this effort in the overviews printed below. This will allow us to look at the court from a more distant perspective, examining the way it created an image of rulership and secured the loyalty of elites.

At or around court, a coercive apparatus was commanded-at least when and where the centre exerted control. Coercion was a precondition for consolidated power, but it was never a sufficient condition. Courts contributed to compliance in two fundamental ways. Firstly, they distributed wealth, offices, privileges, and prestige. The process of redistribution attracted intermediary elites eager for the royal bounty; in the hands of the ruler and his advisors, the control of nominations, rewards, and punishments was a formidable instrument. The population at large did not usually profit directly from the distribution of honours - although on special occasions those able to approach the ruler could partake in the dynastic bounty or benefit from clemency. Secondly, courts were theatres of dynastic legitimacy. Righteous and virtuous rulership was enacted here, in solemn seclusion or boisterous interaction, with religious deference, theatrical flair, or martial show. Was this a show of the ruler for all, of the ruler and the elites for the populace? Above, we have seen that this view is not necessarily wrong, but misses a vital aspect of ritual: its potential to affect participants as well as audiences, and its close connection to shared moral values. Rulers needed to persuade themselves; they were rarely wholly unaffected by the demands of the mandate of heaven-embodied by the people, their dynastic forebears, successors, and the all-seeing eye of higher powers.

Religious sanction, dynastic mythology and lineage, just rulership and the protection of the weak, personal bravery of the ruling princes, and charisma or divine election can be found in dynastic mandates across the globe in differing proportions. While bravery and charisma could be intensely personal, religious sanction, genealogy, and just, harmonious rulership were more institutional. 


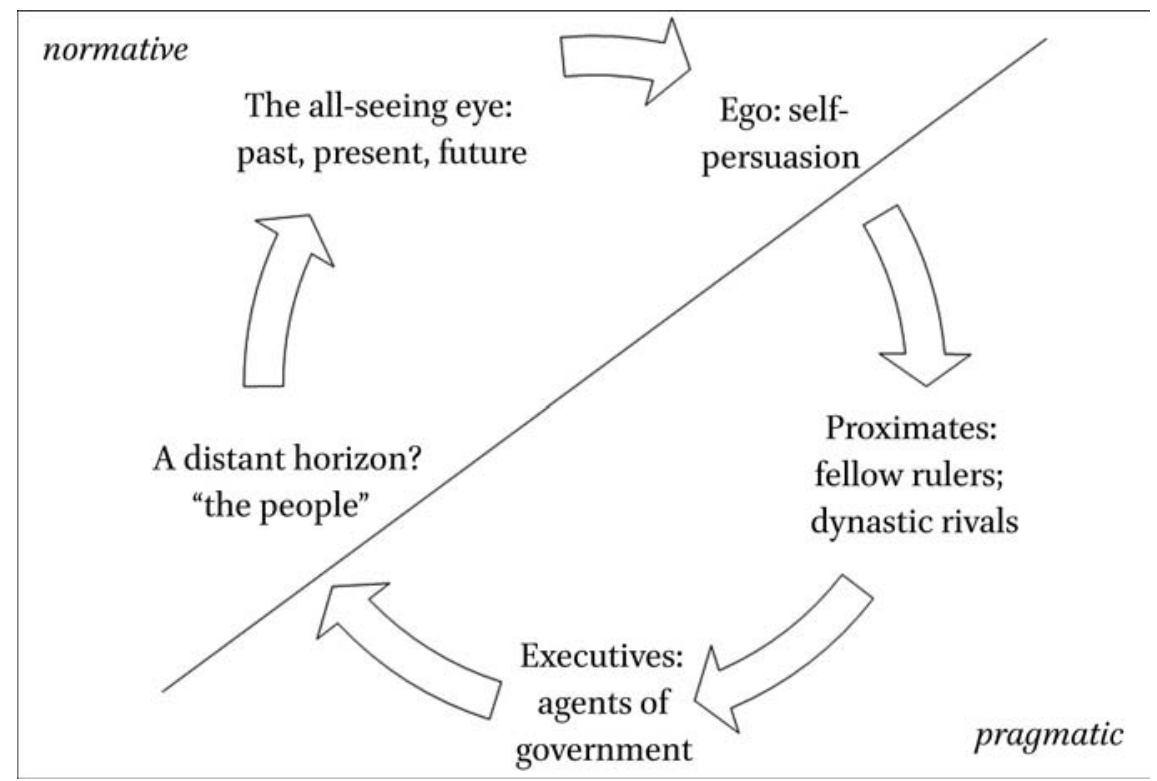

FIGURE 2.2 Top-down: forms of compliance and intended audiences

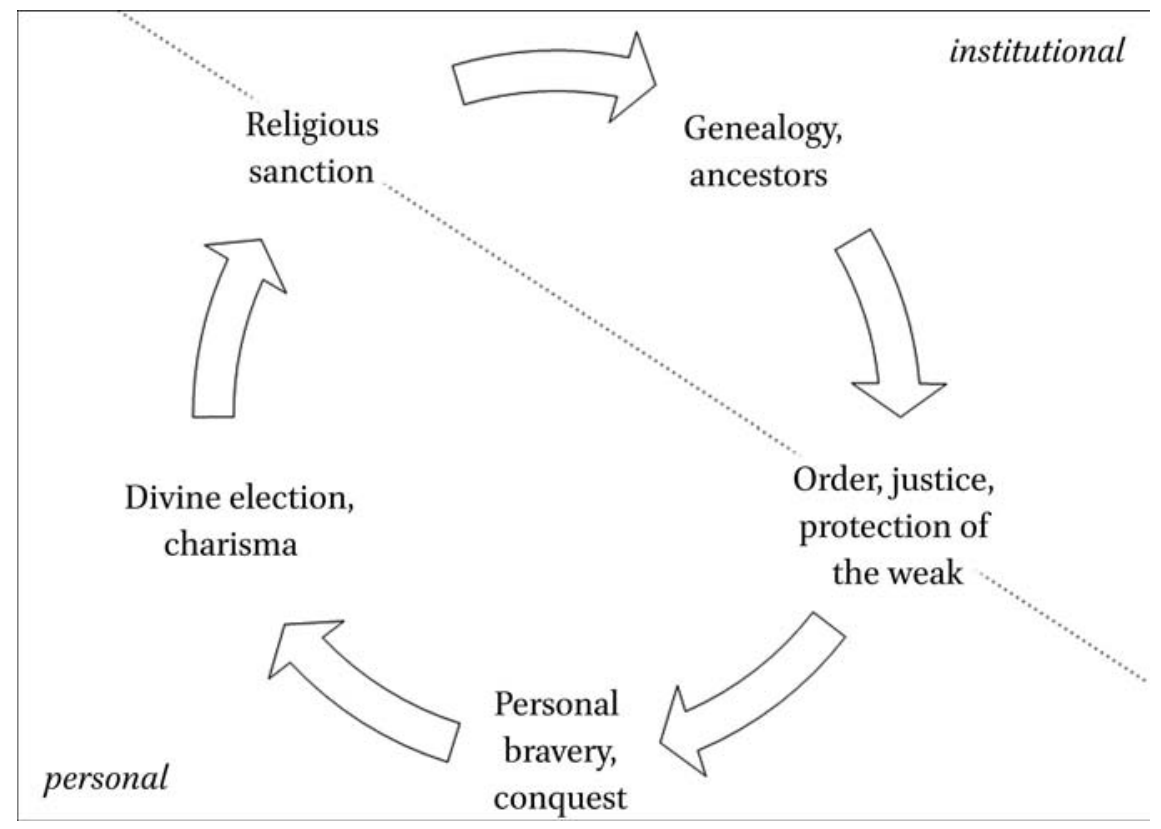

FIGURE 2.3 Common ingredients of the dynastic mandate 
The distribution of honours, rewards - and punishments - affected strongly the central and intermediary elites who formed the backbone of power everywhere. Ensuring their pragmatic compliance through redistribution, as always backed in the last instance by coercion, was a key function of all courts discussed here. The rituals performed at court, important in West and South Asia because they provided a meeting point for distribution and an occasion for interaction with wider social groups, were related everywhere to the religious-moral-normative mandate of rulership. People and heaven are often used almost interchangeably in sources, explicitly so in the Chinese case, elsewhere mostly via religious humility and the moral requirement of just rule. Finally, the court offered a meeting point and an arena for all eager to gain access to decision-making: this was a game with great risks and few easy successes, but it attracted many. The challenge to chart the competition for power around the ruler can be addressed effectively only at the level of detailed case studies-where these are available, we can conclude that there were always more stakeholders involved, even under professed and exalted autocrats.

Founders by definition grab power as generals; from coercion they move to securing recognition among equals and obedience among followers and agents. Booty is conspicuously present in the history of conquerors, from Chinggis's 'warband' elaborated in this volume by Jos Gommans to Napoleon's articulate European 'spoils system' sustaining his imperial elite. ${ }^{224}$ Satisfying followers does not assuage heavenly powers, neither does it bring the loyalty of conquered masses, nor, finally, does it necessarily convince the usurper himself. Conquerors could point to their battlefield success as evidence of divine support but desperately needed confirmation by tradition. Mamluk sultans used the Abbasid heir and nominal caliph in justification of their power; Timur cultivated a male Chinggisid 'puppet-khan' at his court, and used marriage alliances to strengthen his connection to Chinggis. ${ }^{225}$ Napoleon not only introduced a mixture of French royal and Habsburg imperial court traditions; he also tried to obtain the 'Carolingian' coronation relics of the Holy Roman Empire, and in the end he married a Habsburg heiress. The astonishing bric-à-brac of historic examples in his representation notably included Roman imperial and Merovin-

224 See e.g. Geoffrey Ellis, Napoleon (London and New York, 1997) chapter 5: The Social Accretions of Power: The Imperial Notables, Nobility, and 'Spoils System'.

225 See Jeroen Duindam, 'Dynasties', Medieval Worlds. Comparative and Interdisciplinary Studies 2 (2015) 59-78: http://dx.doi.org/10.1553/medievalworlds_no2_2015s59 and the literature cited there. 
gian motifs. Other moves by this latter-day conqueror-emperor fit the attempts of earlier conquerors-founders moving towards order and conformity, perhaps most notably the 1801 concordat with the pope and the latter's subdued presence at the 1804 imperial coronation (in the role of spectator rather than as the officiating dignitary).

Populations, undoubtedly, were never fooled by the proud shows of rulersthey must have followed their own precepts and criteria, emanating from the same worldview, but with differing emphases. Whether the court was effective as a conspicuous centre or overplayed its hand and turned into a caricature, it was the focal point for intermediary elites and an inescapable but distant horizon for the population. Elites in Eurasia were on the lookout for portents of decline and sought to respond effectively to this threat. The Ottomans, a term used here to indicate the ruling dynasty as well as its leading supporters, reinvented the basis of their power several times, in phases of crisis and adaptation from the late sixteenth century onwards, with an increasing role for local elites as tax farmers and military entrepreneurs. European states, locked in a semi-permanent internecine battle gradually implicating the whole world, were able to establish collective global hegemony. A closer look at the polities succeeding in this process shows miniature 'dynastic cycles'. Spanish arbitristas pondered decline as seriously as did their Ottoman colleagues in the decades following $1600 .{ }^{226}$ Everywhere, apparently, the central state first waxed before it gave more room to local and regional elites during phases of acute financial crisis. France, the next most successful European semi-hegemonic state, reached this limit by the end of Louis XIV's reign. The Sun King's redefinition of court-elite relations provided the groundwork for resurgent elite dominance in the eighteenth century. In the aftermath of the Seven Years' War (1756-1763), the compact between rulers and elites was severely tested in all major countries involved: the American War of Independence and the French Revolution both originated in the reforms triggered by war expenditure and towering deficits. The protracted political-military crisis from the 178 os onwards changed the European constellation and confirmed the global dominance of the main players, with Britain emerging as the leading power.

226 A parallel discussed at a conference on the Arbitristas organised by Christian Windler (Bern) and Sina Rauschenbach (Konstanz), see a conference report at http://hsozkult .geschichte.hu-berlin.de/index.asp?id=4853\&view=pdf\&pn=tagungsberichte\&type= tagungsberichte (consulted 24 July 2015). 
The cycles of integration and devolution did not necessarily coincide with dynastic change here or elsewhere. The Ottomans and the Habsburgs weathered several heavy storms, but persisted into the twentieth century-although the Habsburgs changed titles and domains several times and the Ottomans ended with a rump empire. The Safavids experienced invasions and rebellions before Iran saw the meteoric rise of Nader Shah, whose short-lived dynasty was succeeded by the Qajars by the end of the eighteenth century. Mughal decline coincided with the increasing presence and competition of European powers on Indian soil-notably the French and the British. The final decades of the Qianlong emperor display a marked incidence of rebellions and self-serving attitudes of military and civil elites. The Qing, however, persisted into the twentieth century, under increasingly difficult conditions with internal breakdown and European intervention rapidly undermining the coherence of their empire.

What explains the alternation of centripetal and centrifugal phases? Scholars have proffered exogenous and endogenous explanations, with the notion of 'imperial overstretch' emerging as a solution combining elements from both. The financial-military pressure of external challenges triggered internal crisis, or, conversely, internal stalemate between competing powers undermined effective responses against external challenges. Jack Goldstone suggested a neo-Malthusian model based on demography. ${ }^{227}$ The growth of populations, straining agricultural production to its limits, led to an impoverished peasantry, reduced state incomes, and increasing numbers of elite competitors: a highly combustible mixture particularly in a setting of international rivalry. These models all include important clues to the oscillations so obvious in world political history.

Classic cyclical views, particularly Ibn Khaldun's perspective of gradually eroding elite cohesion, add a relevant ingredient. By idealizing the coherence of desert tribes before the adoption of urban luxury, Ibn Khaldun downplayed the element of distribution of spoils so strongly present in most conquests. The disaffection of the old military core group depicted by Ibn Khaldun as a consequence of consolidation, urban amenities, and the ruler's reliance on elites of the pen in fact matches a process we have seen depicted here several times. Dependent and loyal elites themselves change character while consolidating their position; they acquire hereditary rights, become a challenge for the central ruler, and thus incite him to find support among rival groups. Stripped of its

227 Jack A. Goldstone, Revolution and Rebellion in the Early Modern World (Berkeley, 1991); see also Peter Turchin and Sergey A. Nefedov, Secular Cycles (Princeton, 20o9). 
moral overtones, the dynastic cycle can be understood as a neutral description of an oft-repeated process related structurally to the management of distance in large-scale polities and the inevitable presence of intermediary elites. The precision added by Ibn Khaldun, that the sword predominates in the early phase as well as in the downturn of the cycle, is a factual description of the predominance of coercion in phases of political changeover. In China, too, the cultural partiality for literary accomplishment over martial excellence was reversed in bloody phases of changeover. All rulers were subject to the tyranny of distance, and no pre-modern ruler held the means to effectively and lastingly control his agents. The representation of shared ideals and the distribution of rewards for loyal supporters, both concentrated on the court, formed the unavoidable recipe for all, and the successful operation of these processes tended to come to a standstill every few generations because of entrenched elite power, incompetency at court, and external threats.

\section{Outlook: Towards Modernity}

Dynastic power was dominant in the pre-modern world. It rapidly lost ground in the last two centuries. From the eighteenth century onwards, the magicalreligious underpinning of European monarchy eroded among the elites, notably including rulers and courtiers. The reforms and revolutions of the late eighteenth century transformed the political culture of Europe. In the century between $175^{\circ}$ and $185^{\circ}$, coinciding with this phase of profound internal change, the competing states of Europe became the arbiters of the world. All the empires and states discussed here came under severe pressure caused at least in part by the undeniable military, political, and economic ascendancy of Europe.

In Europe, dynastic power persisted. From Napoleon's reconstruction to the shows of royalty in the age of nationalism and imperialism, the politically withdrawing royalty retained a surprisingly strong grip on the popular mind. Constitutional monarchies in modern Europe persist in the margins of the political system, but apparently still have the power to enthral many and gravely annoy others. The resurgence and resilience of dynastic constellations in the Arabic world and in Southeast Asia raises the question whether here the religious underpinning of dynastic power was less severely eroded.

Everywhere patrimonial tendencies can still lead to next-of-kin succession in office. Family businesses, recently, have undergone a positive re-evaluation: according to several recent publications, these companies thanks to their semidynastic structures are better able to survive and flourish in certain condi- 
tions. ${ }^{228}$ Finally, autocrats of all political persuasions, with powers far beyond those of pre-modern tyrants, have tended to make their office hereditary in their clan.

Several questions arise about the wider implications of our examination of dynastic power structures. First of all, do they have an impact on the 'great divergence' debate? Was there a fundamental difference in rulership styles that helps to explain the sudden rise of Europe? This question tends to reduce comparison to the most successful contestants for economic efficiency: usually defined as China's south-eastern seaboard and England, sometimes joined by the Dutch Republic and France. From a comparative Eurasian political perspective, arguably the most marked difference lies in the remarkable military competition of European polities on their own continent and around the globe, which persistently increased financial pressures, and necessitated comprehensive reforms. ${ }^{229}$ This competition was triggered in part by the interweaving of dynastic succession rights, but this cannot be seen as the only or prime mover. When by the end of the Seven Years' War, most European states needed to implement major changes in the relationship with leading elites, to pay their debts and continue competing with their rivals, they were crossing a critical threshold. They did so in an age where elites were challenging, or at least critically examining, received wisdom en bloc. This is a world far removed from the mindset that convinced the Kangxi emperor to freeze the head tax in 1711. The Ottomans were more closely integrated in the European military revolution, and tried their hand at innovations and political reforms many times. Yet their serious military losses and the economic interests also convinced them to accept integration in the European political system. Ottoman ambassadors were present in European capitals long before China would even consider reciprocity with European leaders. ${ }^{230}$ The practices of rule at the dynastic court, it seems to me, did not necessarily give Europe an advantage over all polities in West, South, or East Asia. It followed rather than initiated changes that were related primarily to military competition and global expansion. ${ }^{231}$

228 David S. Landes, Dynasties: Fortunes and Misfortunes of the World's Great Family Businesses (New York, 2006); see also Stephen Hess, America's Political Dynasties. From Adams to Clinton (Washington, 2015).

229 See a recent work stressing multipolarity and permanent military competition Hoffman, Why Did Europe Conquer the World?

230 Russia, with the 1689 Treaty of Nerchinsk, appears to be the exception here; on Kangxi and the Russian ambassador Ismailov in 1721, see John Bell, A Journey from St. Petersburg to Pekin, 1719-1722, J.L. Stevenson, ed. (Edinburgh, 1966).

231 Vries, State, Economy and the Great Divergence. 


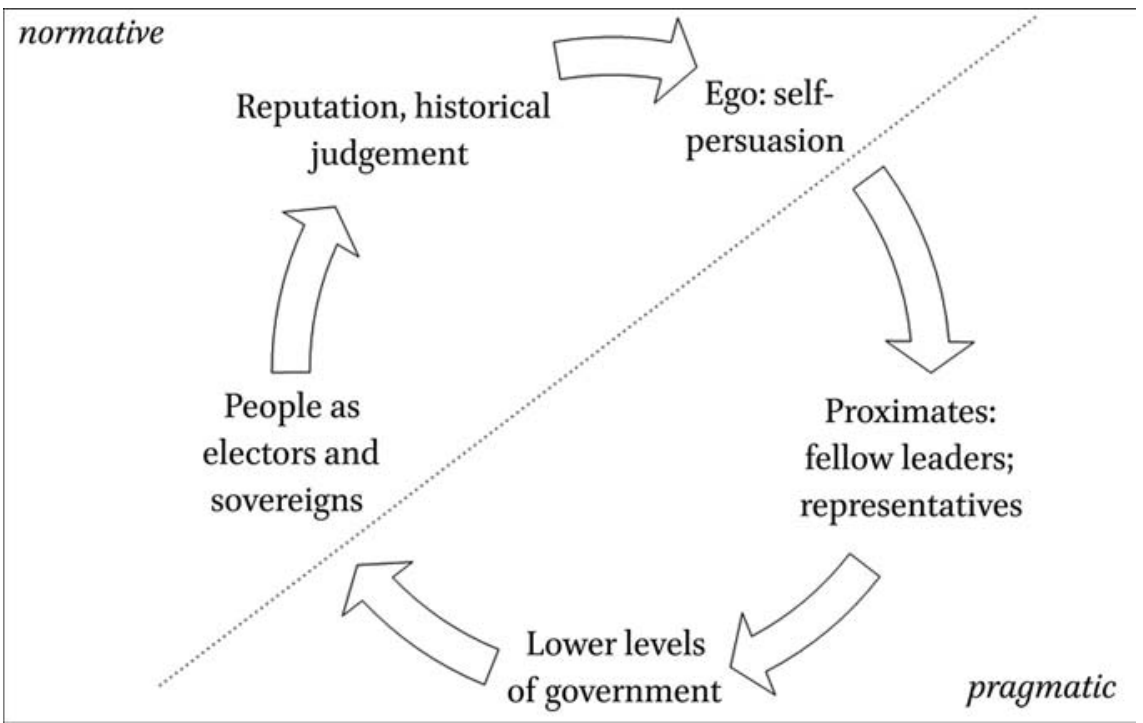

FIGURE 2.4 Top-down:forms of compliance and modern intended audiences

Forms of compliance changed fundamentally in the centuries following the French Revolution. The mandate of heaven was now transformed in one stroke into a people's mandate. This breakthrough at the same time led to a restatement in secular terms of a notion that had always been present in the mandate of heaven: the well-being of the people had always been of prime importance, at least in theory. The coercive apparatus of modern states is far more powerful; yet on the whole, states no longer invest the biggest share of their revenue in war debts and armed forces, as was the case in most pre-modern polities. States have taken on numerous and diverse responsibilities, organizing in a highly institutionalized way the redistribution that took shape around courts. Surely, moreover, popular approval is now, at least in most states, a key issue: polls can change policies overnight. Leaders have at their disposal a multimedia circus to broadcast their views and, possibly, to create the sense of belonging that might earlier have taken shape during ritual meeting points. However, in democracies with a free press, other voices and views will have access to the same instruments. One tantalizing question reaches far beyond the constraints and possibilities of this chapter: can the differences observed here between centres of power in Eurasia be extended to the modern world? Do familiar older contrasts persist in the modern world, as part of lasting regional-cultural differences? Or are current political divergences the consequence primarily of modern dynamics, the long-lasting hegemony of Europe, the unequal spread of wealth and opportunities, and political contingencies in every region? While 
there is no easy answer to this question it is clear that regional cultural-political specificities do have a role to play.

Finally, does the modern world still follow the cyclical pattern so persistently present in previous centuries? States may no longer 'breathe' in the style of empires with diffuse frontier zones: well-defined borders and highly articulate views of sovereignty prevent this. However, it may still be possible to ascertain a waxing and waning of political cohesion within states. The disruptions caused by warfare and pandemics may give rise to phases of greater social cohesion. ${ }^{232}$ Social groups and outlying regions experience moments of commitment to the centre, as well as phases of disaffection. Peter Bol, examining Chinese history in a long-term overview, establishes a steady alternation between central and local forces from imperial China into PRC times. ${ }^{233}$ The common tendency to think in terms of generations, moving from 'builders' to 'consumers', from commitment and hard work to pleasure and entitlement, is still with us.

232 See a plausible but crude statement, Walter Scheidel, The Great Leveler: Violence and the History of Inequality from the Stone Age to the Twenty-First Century (Princeton, 2017).

233 Peter Bol, "The "Localist Turn" and "Local Identity" in Later Imperial China', Late Imperial China 24, no. 2 (2003) 1-50. 